\begin{abstract}
Universidade de São Paulo
Faculdade de Medicina de Ribeirão Preto

Departamento de Neurociências e Ciências do Comportamento
\end{abstract}

\title{
INIBIDORES DE FOSFATIDILINOSITOL-3-CINASE (PI3K) E NEUROPROTEÇÃO MEDIADA PELA CASCATA DE SINALIZAÇÃO DA AKT NA FASE AGUDA DO MODELO DE PILOCARPINA
}

Priscila Alves Balista

Ribeirão Preto

2010 


\section{Priscila Alves Balista}

\section{INIBIDORES DE FOSFATIDILINOSITOL-3-CINASE (PI3K) E NEUROPROTEÇÃO MEDIADA PELA CASCATA DE SINALIZAÇÃO DA AKT NA FASE AGUDA DO MODELO DE PILOCARPINA}

Dissertação apresentada ao Departamento de Neurociências e Ciências do Comportamento da Faculdade de Medicina de Ribeirão Preto para obtenção do Título de Mestre em Ciências Médicas

Área de concentração: Neurologia Opção: Neurociências

Ribeirão Preto

2010 


\section{INIBIDORES DE FOSFATIDILINOSITOL-3-CINASE (PI3K) E NEUROPROTEÇÃO MEDIADA PELA CASCATA DE SINALIZAÇÃO DA AKT NA FASE AGUDA DO MODELO DE PILOCARPINA}

Dissertação apresentada ao Departamento de Neurociências e Ciências do Comportamento da Faculdade de Medicina de Ribeirão Preto para obtenção do Título de Mestre em Ciências Médicas

Área de concentração: Neurologia

Opção: Neurociências

COMISSÃO JULGADORA

Presidente e Orientador: Prof. Dr. João Pereira Leite

Examinador: Prof. Dr. Norberto Cysne Coimbra

Examinador: Profa. Dra. Maria José da Silva Fernandes

Aprovado em 
"A verdadeira medida de um homem não é como ele se comporta em momentos de conforto e conveniência, mas como ele se mantém em tempos de controvérsia e desafio" Martin Luther King Jr. 
Dedico este trabalho a minha mãe Edna, que me conhece pelo olhar, é intérprete dos meus desejos, que transforma momentos pela força do seu abraço e me ensinou o poder que há em um sorriso. À melhor mãe do mundo, por tudo que ela representa para mim e por nunca ter poupado esforços para que eu pudesse me dedicar aos estudos e à realização de todos os meus sonhos.

A minha adorável madrinha "Tia Ana" que sempre me incentivou, motivou e acreditou em mim. Obrigada também por nunca ter poupado esforços à realização dos meus maiores desejos.

Ao meu irmão Ridan, pela força, presença, incentivo, motivação em cada momento deste trabalho; meu eterno guardião!

Ao meu "pai" de coração José Tadeu a quem muito tenho a agradecer pela presença constante $\mathrm{e}$ motivadora.

A minha querida avó Elza (in memoriam), que vivenciou o início desta jornada, e, agora, eu dedico a ela este belo final.

Aos meus tios Afrânio e Edinéia e primos Leonardo e Erika. 


\section{AGRADECIMENTOS}

A Deus, pelo dom da vida, pelas bênçãos derramadas e pela graça de fazer-me enxergar, através da ciência, as maiores evidências da sua existência.

Ao Prof. Dr. João Pereira Leite por ter acreditado em mim, ter me acolhido desde o primeiro momento e pela paciência e competência científica. Agradeço-lhe pela sua orientação e por ter me proporcionado um grande crescimento científico.

Ao Prof. Dr. Rodrigo N. Romcy Pereira, pela colaboração e elaboração deste trabalho.

A Renata Caldo Scandiuzzi, pelos ensinamentos, envolvimento e dedicação ao meu trabalho; uma pessoa muito querida.

À Dra. Ludmyla Kandratavicius, pela sua participação, ensinamentos e presença constante nos momentos de dúvidas.

A José Eduardo, Ana Claudia, Graziela, Raquel, Mariana e Aline, por terem compartilhado seus conhecimentos e estarem sempre dispostos a ajudar; pessoas incríveis.

Aos colegas da eletrofisiologia, Ana Clara, Jana, Cleiton, Rafael, Matheus e Lézio, por terem sido sempre prestativos.

Ao Dr. José Willegaignon de Amorim de Carvalho pelo incentivo, motivação e pela grande amizade.

A Tâmara Mota, Flávia Toledo, Eduardo Umeoka e Juliana Leão, pessoas que fazem parte da minha história.

A Renato Meirelles, pelo suporte técnico na captação de imagens, sempre prestativo e disposto ajudar.

Ao Departamento de Neurociências e Ciências do Comportamento da Faculdade de Medicina de Ribeirão Preto da Universidade de São Paulo, pelo suporte acadêmico e estrutural.

Às secretárias do departamento de Neurociências e Ciências do Comportamento, pela disponibilidade e atenção.

Ao Conselho Nacional de Desenvolvimento Científico e Tecnológico (CNPq), pela concessão da bolsa de mestrado para a realização desta pesquisa.

Meus sinceros agradecimentos, e não menos importantes, a todos aqueles que por ventura eu tenha esquecido de mencionar anteriormente, mas que fizeram parte e auxiliaram direta ou indiretamente a execução deste estudo. 


\section{RESUMO}

Introdução: A epilepsia do lobo temporal (ELT) é a forma mais frequente de epilepsia em adultos. Um modelo experimental de ELT consiste na indução de status epilepticus (SE) em animais por administração de Pilocarpina. Este modelo induz mudanças patofisiológicas e comportamentais em ratos muito semelhantes às observadas em seres humanos com ELT. Apesar da literatura apresentar dados relacionados às respostas celulares, pouco se conhece a respeito do envolvimento de cascatas de sinalização com insultos epileptogênicos no sistema nervoso. A enzima fosfatidilinositol-3-cinase (PI3K) está envolvida na ativação da cascata de sinalização intracelular da Akt. A Akt é uma proteína cinase especifíca de serina/treonina cuja forma ativa proporciona um controle no crescimento e proliferação celular, bem como induz um "sinal de sobrevivência" para a proteção de células contra a apoptose. Alguns estudos mostram que a ativação da PI3K é inibida por potentes drogas, tais como a LY294002 e a Wortmanina. A PI3K ativa a Akt e a cascata de sinais extra e intracelulares neuroprotetores pós-insultos. O estudo da ação de inibidores da PI3K em modelos de epilepsia pode fornecer dados sobre o envolvimento da Akt em sinais neuroprotetores. Objetivos: Avaliar o efeito do $S E$ por injeção intra-hipocampal de Pilocarpina na ativação da Akt, bem como os efeitos do bloqueio desta cascata sobre as alterações patológicas observadas no hipocampo de ratos na fase aguda pós-SE. Metodologia: Ratos da cepa Wistar machos (250-300 g) foram divididos em grupos de tratamento, sendo tratados com injeções ipsilaterais na região posterior do hipocampo, com uma hora de intervalo entre drogas, das drogas: Salina e Pilocarpina (grupo Sal+Pilo), LY294002 e Pilocarpina (LY+Pilo) e Wortmanina e Pilocarpina (Wort+Pilo). No grupo considerado como controle foram injetadas as seguintes drogas: Salina e Salina (grupo Sal+Sal) ou Dimetilsulfóxido e Salina (grupo DMSO+Sal). O tempo de $S E$ induzido por Pilocarpina foi fixado em 2 horas. Grupos de animais foram sacrificados nos instantes de 1 dia e 7 dias após o SE e seus encéfalos foram processados objetivando a imuno-histoquímica 
para NeuN, GFAP e Akt (pan). Resultados: A densidade neuronial na região do hilo do hipocampo foi menor no grupo Sal+Pilo, seguido dos grupos LY+Pilo e Wort+Pilo, avaliando-se os vários níveis de formação hipocampal e região posterior. Para a análise da astrogliose, na camada granular, o grupo LY+Pilo apresentou maior número de astrócitos positivos; na região do hilo hipocampal, os grupos LY+Pilo e Wort+Pilo apresentaram baixa expressão para a proteína Akt, comparados aos grupos Controles; assim como o grupo Wort+Pilo, em CA2, apresentou baixa expressão da proteína Akt somente na região posterior. Os animais Sal+Pilo sobrevida-7dias pós-SE revelaram maior expressão da Akt quando comparados com o grupo Sal+Pilo sobrevida-1dia pós-SE. Quanto à análise comportamental, o grupo Wort+Pilo apresentou maior latência para o início do $S E$ que o grupo Sal+Pilo, não sendo observado diferença de severidade, uma vez atingido o $S E$. Conclusões: Na hipótese de trabalho, o uso de inibidores da fosforilação de Akt resultaria em maior morte neuronial, astrogliose e expressão inalterada da Akt. Ao contrário do esperado, os grupos que receberam injeções intra-hipocampais de inibidores de Akt, antes da indução de $S E$, exibiram menor perda neuronial, menor astrogliose e menor expressão da Akt para os vários níveis de formação hipocampal e no hipocampo posterior. Porém, o grupo Sal+Pilo sobrevida-7 dias pós-SE exibiu maior expressão para Akt quando comparado com o grupo Sal+Pilo de sobrevida-1 dia pós-SE. Além disso, o pré-tratamento com Wortmanina demonstrou um maior tempo de latência para o início do $S E$, o que nos sugere uma maior neuroproteção do que LY294002. 


\section{ABSTRACT}

Introduction: Temporal lobe epilepsy (TLE) is the most frequent type of adult human epilepsy. An experimental model of TLE, the Pilocarpine induced epilepsy, followed by pathofisiologic and behavioural alterations in rats resembling human diagnosis with TLE. Although there are several data on cell response in literature, few information exist on the cascade of signals involved in epileptogenesis process of central nervous system. The phosphatidylinositol-3-kinase (PI3K) is involved in activation of Akt intracellular signaling cascade. The serine/threonine kinase Akt, that in active form promote a control of growth and cell proliferation, such as "survival sign" protecting cells from apoptosis. Some studies have shown that activation of PI3K is blocked by potents pharmacological inhibitors, for example the LY294002 and Wortmannin. PI3K activate Akt and both extra and intracellular cascade signals involved in neuroprotection after seizures. The study of inhibitors mechanism in model of epilepsy can provide information on the involvement of Akt in signals of neuroprotection. Objectives: To evaluate the effects of $S E$ by the intrahippocampal injection of Pilocarpine in Akt activation, and the effects of the blockade of this cascade on pathologic alterations observed in hippocampus of rats in acute phase after $S E$ as well. Methods: Male Wistar rats (weighing 250 to $300 \mathrm{~g}$ ) were divided in groups treated ipsilaterally with injections in the posterior region of hippocampus with an elapsed time of one hour subsequently after each injection of following substances: Physiological Saline and Pilocarpine (group Sal+Pilo), LY294002 and Pilocarpine (LY+Pilo), and Wortmannin and Pilocarpine (Wort+Pilo). Control groups were treated with the following drugs Saline + Saline (group Sal+Sal) or Dimethylsulphoxide + Saline (DMSO+Sal). A fixed time of 2 hours was considered for evaluating the $\boldsymbol{S E}$ induced by Pilocarpine. Animals were sacrificed 1 day and 7 days after $S E$, and their brains were processed imunohistochemically for NeuN, GFAP and Akt (pan) detecting. Results: The neuronal density in the hippocampal hilus was lower in 
the Sal+Pilo group, followed by LY+Pilo and Wort+Pilo groups, this evaluate various levels of hippocampal formation and posterior region. For the analysis of reactive astrogliosis of the granular cell layer, the LY+Pilo group presented a great number of GFAP-positive astrocytes. In the hilar region, the LY+Pilo and Wort+Pilo groups presented a reduced Akt expression compared to the Control group, such as the group Wort+Pilo in CA2, presented a reduced Akt expression only in posterior region. The Sal+Pilo animals with a survival time of 7 days after SE revealed higher Akt expression when compared to the Sal+Pilo animals with a survival time of 1 day._In behavioural analysis, the Wort+Pilo group presented major time of latency to $S E$ than Sal+Pilo group, without differences in the disease severity, once reached the $S E$. Conclusions: On the contrary to the original hypothesis of this work, the use of inhibitors of Akt phosphorylating resulted in an unaltered neuronal death, astrogliosis and Akt expression. The groups that received intrahippocampal injection of Akt inhibitors before inducing $S E$ exhibited a reduced neuronal loss, astrogliosis and Akt expression to the various levels of hippocampal formation and posterior region. But, to the Sal+Pilo group with a survival time of 7 days after $S E$ induction exhibited greater Akt expression than Sal+Pilo group with a survival time of 1 day after $S E$ induction. However, the pretreatment with Wortmannin displayed major time of latency to $S E$ induction, suggesting this substance as a better neuroprotector than LY294002, according to the methodology applied in this study. 


\section{LISTA DE FIGURAS}

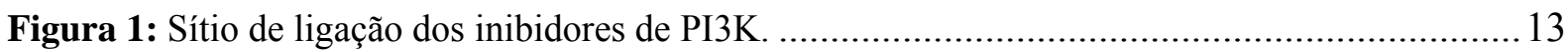

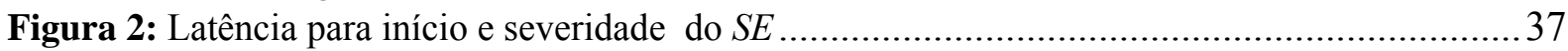

Figura 3: Densidade neuronal (sítio da injeção versus lado contralateral) nos grupos DMSO+Sal e

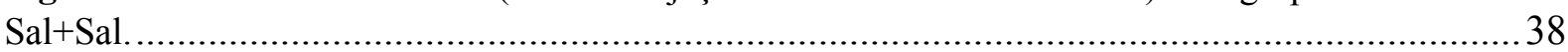

Figura 4: Densidade neuronal (sítio da injeção versus lado contralateral) nos grupos LY+Pilo,

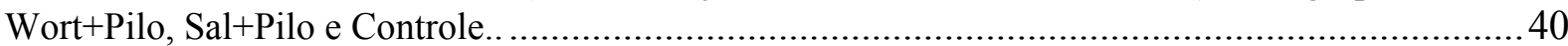

Figura 5: Imunorreatividade para GFAP(sítio da injeção versus lado contralateral) nos grupos

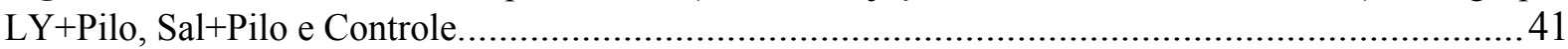

Figura 6: Imunorreatividade para Akt (sítio da injeção versus lado contralateral) nos grupos LY+Pilo, Wort+Pilo, Sal+Pilo e Controle.

Figura 7: Densidade neuronal (análise do lado ipsilateral à injeção, valores médios entre as regiões anterior, média e posterior) na imunohistoquímica para NeuN nos grupos LY+Pilo, Wort+Pilo, Sal+Pilo e Controle..

Figura 8: Secções coronais no hipocampo (análise do lado ipsilateral à injeção, valores médios entre as regiões anterior, média e posterior), imunomarcada para NeuN nos grupos Controle, LY+Pilo, Wort+Pilo e Sal+Pilo-sobrevida 7 dias pós-SE

Figura 9: Imunorreatividade para GFAP(análise do lado ipsilateral à injeção, valores médios entre as regiões anterior, média e posterior) nos grupos LY+Pilo, Sal+Pilo e Controle.

Figura 10: Secções coronais no hipocampo (análise do lado ipsilateral à injeção, valores médios entre as regiões anterior, média e posterior), imunomarcada para GFAP nos grupos Controle, LY+Pilo e Sal+Pilo-sobrevida 7 dias pós-SE....

Figura 11: Imunorreatividade para Akt avaliada no hipocampo (análise do lado ipsilateral à injeção, valores médios entre as regiões anterior, média e posterior) nos grupos LY+Pilo, Wort+Pilo, Sal+Pilo e Controle.

Figura 12: Secções coronais no hipocampo (análise do lado ipsilateral à injeção, valores médios entre as regiões anterior, média e posterior) expressando imunorretividade para Akt nos grupos Controle, LY+Pilo, Wort+Pilo e Sal+Pilo-sobrevida de 7 dias pós-SE.

Figura 13: Densidade neuronal média na região posterior do hipocampo para NeuN nos grupos LY+Pilo, Wort+Pilo, Sal+Pilo e Controle.

Figura 14: Imunorreatividade para GFAP na região posterior do hipocampo nos grupos LY+Pilo, Sal+Pilo e Controle..

Figura 15: Imunorreatividade para Akt na região posterior do hipocampo nos grupos LY+Pilo,

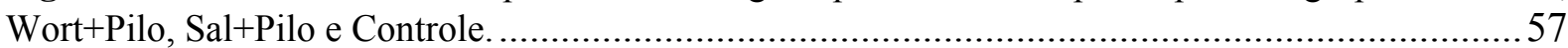

Figura 16: Imunorreatividade para Akt (sítio da injeção versus lado contralateral) nos grupos Sal+Pilo-sobrevida 1 dia pós-SE e Sal+Pilo-sobrevida 7 dias pós-SE ...........................................59 Figura 17: Imunorreatividade para Akt nos vários níveis de formação hipocampal nos grupos Sal+Pilo-sobrevida 1 dia pós-SE e Sal+Pilo-sobrevida 7 dias pós-SE..

Figura 18:. Secções coronais da formação hipocampal, imunomarcada para Akt (lado ipsilateral à injeção da Pilo) nos grupos Sal+Pilo-sobrevida de 1 dia pós-SE e Sal+Pilo-sobrevida de 7 dias pós-SE

Figura 19: Imunorreatividade para Akt avaliada na região posterior do hipocampo nos grupos Sal+Pilo-sobrevida 1 dia pós-SE e Sal+Pilo-sobrevida 7 dias pós-SE.. 


\section{LISTA DE TABELAS}

Tabela 1: Protocolo experimental

Tabela 2: Número de animais inseridos em cada grupo de estudo

Tabela 3: Densidade neuronal média no hipocampo (sítio de injeção versus lado contralateral) avaliada nas lâminas coradas para NeuN.

Tabela 4: Densidade neuronal média no hipocampo (análise do lado ipsilateral à injeção, valores médios entre as regiões anterior, média e posterior) avaliada nas lâminas coradas para NeuN

Tabela 5: Imunorreatividade para GFAP no hipocampo (análise do lado ipsilateral à injeção, valores médios entre as regiões anterior, média e posterior).

Tabela 6: Imunorreatividade para Akt no hipocampo (análise do lado ipsilateral à injeção, valores médios entre as regiões anterior, média e posterior ).

Tabela 7: Densidade neuronal média na região posterior do hipocampo nas lâminas processadas para a imunohstoquímica de NeuN.

Tabela 8: Análise da imunorreatividade para Akt na região posterior do hipocampo.

Tabela 9: Análise da imunorreatividade para Akt no hipocampo (sítio de injeção versus lado contralateral nos grupos Sal+Pilo sobrevida-1 dia e Sal+Pilo sobrevida-7 dias pós-SE 58

Tabela 10: Análise da imunorreatividade para Akt no hipocampo (lado ipsilateral à injeção, valores médios entre as regiões anterior, média e posterior) nos grupos Sal+Pilo sobrevida-1 dia e Sal+Pilo sobrevida-7 dias pós-SE 


\section{LISTA DE ABREVIATURAS}

Akt

AMPc

ANOVA

AS160

ATM

ATP

$\mathrm{Bad}$

Bax

Bcl-2

Bcl-w

Bcl-x

BFM

Bid

Bim

$\mathrm{Ca}^{++}$

CA1

CA2

CA3

CETEA

$\mathrm{c}-\mathrm{Myb}$

COBEA

CREB

CREs

c-Src

DAB

DMSO

DNA-PK

EEG

ELT

e-NOS

FADD

FJ

FKHR (FoxO ou FH)

FoxO

FoxO1

FoxO2

FoxO3A

FoxO4

GD

GFAP

GLUT4

GSK3

GTP

$\mathrm{H}_{2} \mathrm{O}_{2}$
Homóloga celular ao oncogene v-Akt

Adenosina 3,5-monofosfato

Análise de variância

Substrato da Akt de $160 \mathrm{kDa}$

Genes da ataxia telangiectasia mutantes

Adenosina trifosfato

Bcl-2 antagonista de células de morte (Bcl-2 antagonist of the cell death)

Bcl-2 associado a protein X (Bcl-2 associated X protein)

Oncogene da célula B (B-cell lymphoma 2$)$

Antiapoptotic bcl-2 family member

Bcl-2 related gene

Brotamento das fibras musgosas

Domínio agonista interagindo com BH3 (BH3-interacting domain agonist)

Bcl-2-interacting Killer

Cálcio

Região 1 do Corno de Amon

Região 2 do Corno de Amon

Região 3 do Corno de Amon

Comissão de Ética em Experimentação Animal da FMRP-USP

(proto-oncogene protein)

Colégio Brasileiro de Experimentação Animal

Proteína de ligação ao elemento de resposta ao AMPc (cyclic

$A M P$ - response element-binding protein)

Crises recorrentes espontâneas

C-src "tyrosine kinase"

Tetrahidrocloreto de 3,3`-diaminobenzidina

Dimetilsulfóxido

Proteína cinase dependente do DNA

Eletroencefalograma

Epilepsia do Lobo Temporal

Óxido nítrico sintetase endotelial

Proteína Fas-associada com domínio de morte

Fluoro-Jade

Fatores de transcrição da forquilha (forkhead transcription factors)

(Forkhead box $0 X$-containig protein, $O$ sub-family)

(Forkhead box 01)

(Forkhead box 02)

(Forkhead box 03A)

(Forkhead box 04)

Giro denteado

Proteína ácida fibrilar glial (glial fibrilary acidic protein)

Transportador de glicose do tipo 4

Glicogênio sintase cinase 3

Guanosina trifosfato

Peróxido de hidrogênio 


\begin{tabular}{|c|c|}
\hline HeLa & Linhagem imortal de células humanas \\
\hline HM & Motivo hidrofóbico \\
\hline $\mathrm{IC}_{50} \mathrm{~S}$ & Concentração inibitória média \\
\hline icv & Intracerebroventricular \\
\hline IKK & Complexo cinase $\mathrm{IkB}$ \\
\hline ILAE & International League Against Epilepsy \\
\hline ILK1 & Proteína cinase liga a integrina-1 \\
\hline im & Intramuscular \\
\hline ip & Intraperitoneal \\
\hline JurkatT & $\begin{array}{l}\text { Linhagem de lnfócitos } \mathrm{T} \text { derivada de leucemia/linfoma de células } \\
\mathrm{T} \text { do adulto }\end{array}$ \\
\hline LKB1 & Cinase 1 serina/treonina (serine/threonine kinase 1) \\
\hline LY & Inibidor de PI3K (LY294002) \\
\hline MAPK & $\begin{array}{l}\text { Proteína cinase mitógeno ativada (mitogen-activated protein- } \\
\text { kinase) }\end{array}$ \\
\hline $\begin{array}{l}\text { MAPKAPK2 } \\
\text { mcL-1 }\end{array}$ & $\begin{array}{l}\text { Proteína cinase ativada por proteína cinase de mitógeno } \\
\text { (the myeloid cell leukemia-1) }\end{array}$ \\
\hline Mdm2 & Minuto dobro murin 2 (murine double minute 2) \\
\hline mTOR & $\begin{array}{l}\text { Proteína alvo da rapamicina em mamífero (the mammalian target } \\
\text { of rapamycin) }\end{array}$ \\
\hline mTORC1 & Complexo 1 de m-TOR \\
\hline $\mathrm{NeuN}$ & Antígeno neuronial nuclear \\
\hline NF-kB & Fator de transcrição nuclear kappa B \\
\hline NMDA & N-metil-D-aspartato \\
\hline P.V.P.I & Povidine \\
\hline p-53 & Cinase reguladora de morte celular \\
\hline $\mathrm{p} 70^{\mathrm{S} 6 \mathrm{~K}}$ & p70 ribosomal S6 cinase \\
\hline PBS & Tampão fosfato salina \\
\hline PC12 & Linhagem celular derivada de feocromocitoma \\
\hline PDK1 & Proteína cinase dependente de fosfoinositídeos- 1 \\
\hline PDK2 & Proteína cinase dependente de fosfoinositídeos-2 \\
\hline PE & Polietileno \\
\hline $\mathrm{PH}$ & $\begin{array}{l}\text { Domínio de homologia à plecstrina N-terminal (pleckstrin } \\
\text { homology) }\end{array}$ \\
\hline PI3K & Fosfatidilinositol-3-cinase \\
\hline PI4K & Fosfatidilinositol-4-cinase \\
\hline Pilo & Pilocarpina \\
\hline PIP2 & Fosfoinositol-bi-fosfato \\
\hline PIP3 & Fosfoinositol-tri-fosfato \\
\hline PKA & Proteína cinase A \\
\hline PKC & Proteína cinase $\mathrm{C}$ \\
\hline PKC- $\beta \mathrm{II}$ & Proteína cinase $\mathrm{C}$ beta II \\
\hline PRAS40 & (proline-rich Akt substract of $40 \mathrm{kDa}$ ) \\
\hline Ptdlns $(3,4) \mathrm{P} 2$ & Fosfatidilinositol 3,4-bi-fosfato \\
\hline Ptdlns 4-P & Fosfatidilinositol 4-fosfato \\
\hline $\operatorname{Ptdlns}(3,4,5) \mathrm{P}_{2}$ & Fosfatidilinositol 3,4,5-tri-fosfato \\
\hline $\operatorname{Ptdlns}(4,5) \mathrm{P}_{2}$ & Fosfatidilinositol 4,5-bi-fosfato \\
\hline Rab-GAP & (GTPase-activating protein [GAP] domain) \\
\hline $\mathrm{Rac}$ & Relacionado às cinases A e C \\
\hline RTKs & Receptores de tirosina cinase \\
\hline
\end{tabular}


S473

Sal

SE

SREBPs

T308

THC

TORC1

TORC2

TSC-1

TSC-2

TUNEL

UVB

Wort
Serina 473

Salina

\section{Status Epilepticus}

Proteína ligadora do elemento regulatório de esterol (sterol regulatoty element bind protein)

Treonina 308

Delta-9-tetra-hidrocanabinol

Alvo da rapamicina complexo 1

Alvo da rapamicina complexo 2

Complexo esclerose tuberosa 1 (tuberous sclerosis complex 1)

Complexo esclerose tuberosa 2 (tuberous sclerosis complex 2)

Marcação de terminações dUTP pela deoxinucleotidil transferase terminal (terminal deoxynucleotidyl transferase-mediated

biotinylated UTP nick in labeling)

Raio ultravioleta B

Inibidor de PI3K (Wortmanina) 


\section{SUMÁRIO}

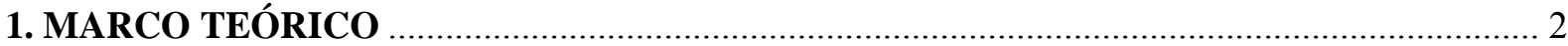

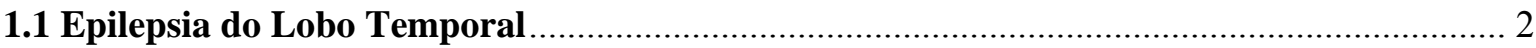

1.2 Modelos experimentais de Epilepsia do Lobo Temporal ……............................................. 3

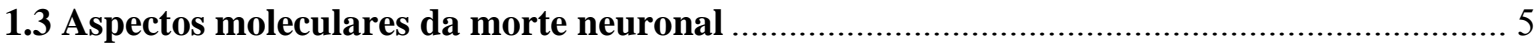

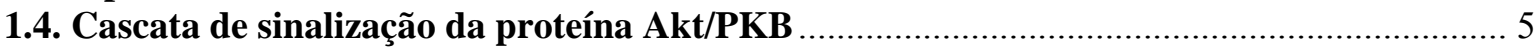

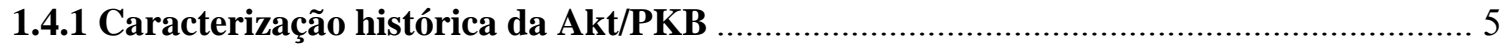

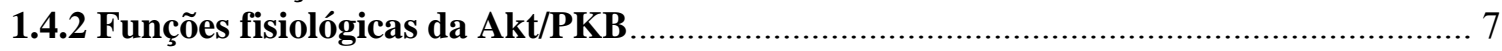

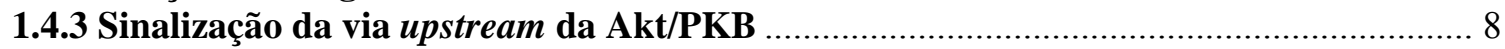

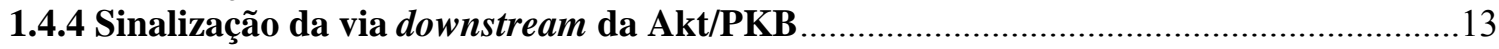

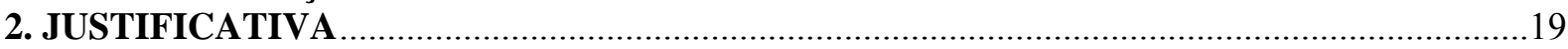

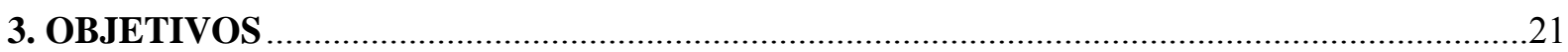

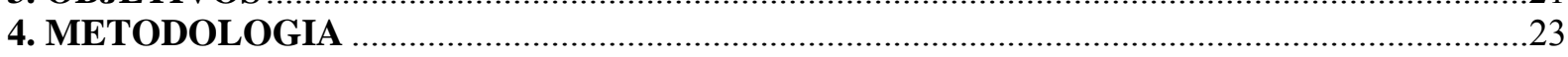

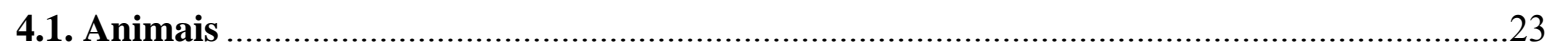

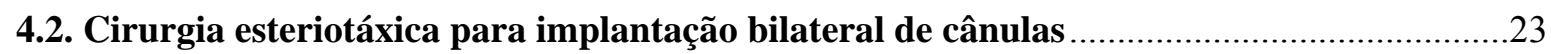

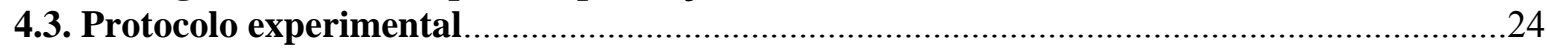

4.4. Indução de Status Epilepticus por administração de Pilocarpina ........................................25

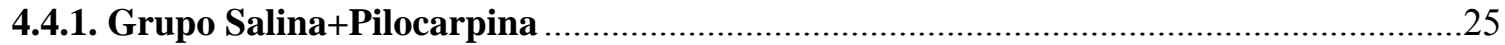

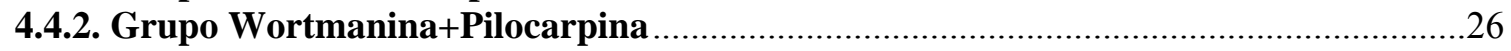

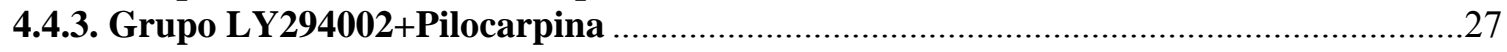

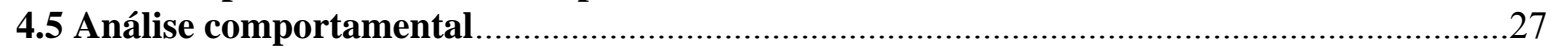

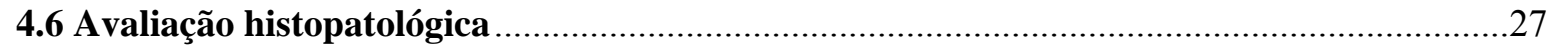

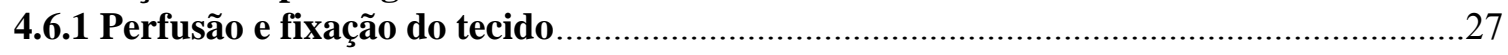

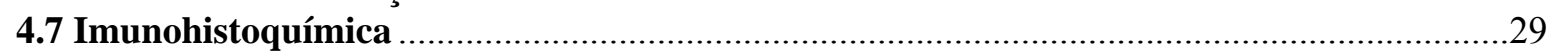

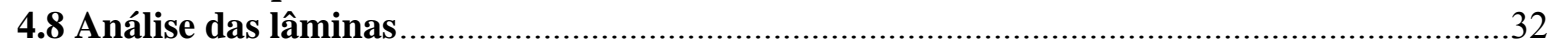

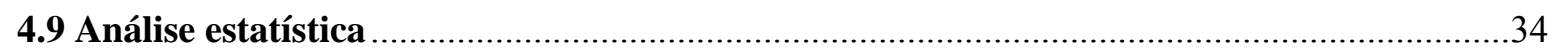

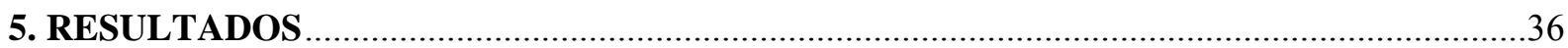

5.1 Mortalidade e distribuição dos animais no protocolo experimental. ....................................36

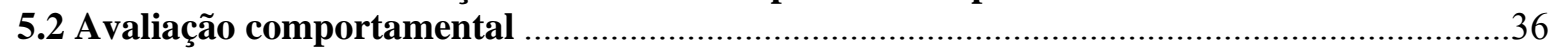

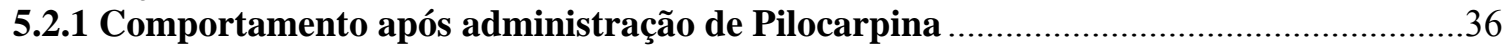

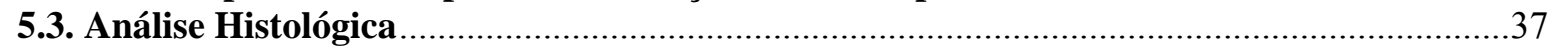

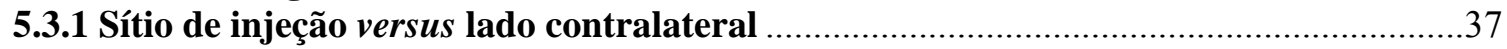

5.3.2 Densidade Neuronal Média no hipocampo (análise ipsilateral à injeção de Pilo, valores

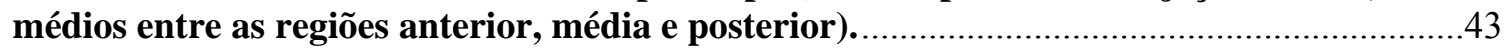

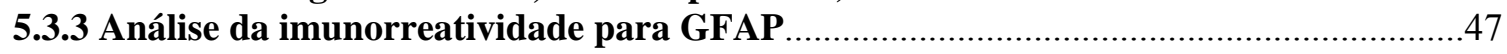

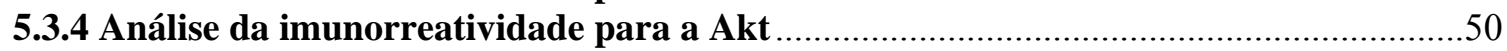

5.3.5 Densidade Neuronal Média (ipsilateral à injeção de Pilo) na região posterior do

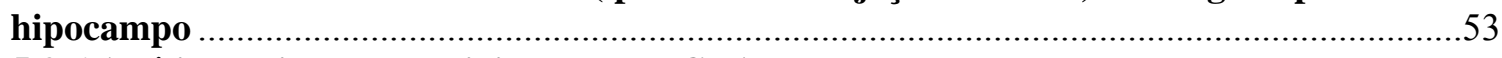

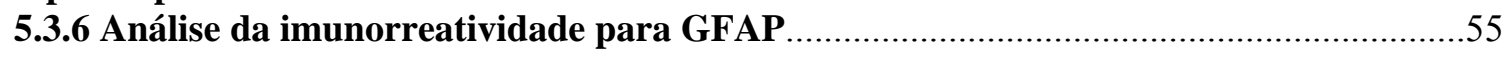

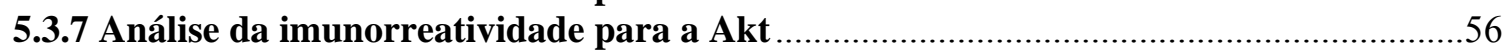

5.4. Análise da expressão da Akt para o grupo Sal+Pilo-sobrevida 1 dia e Sal+Pilo-sobrevida 7

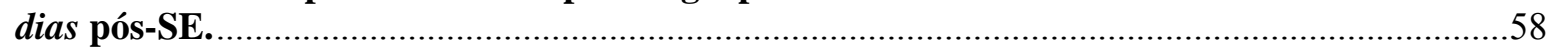

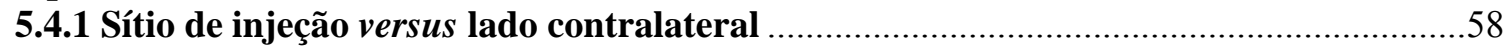

5.4.2 Análise da expressão da Akt no hipocampo (lado ipsilateral à injeção, valores médios

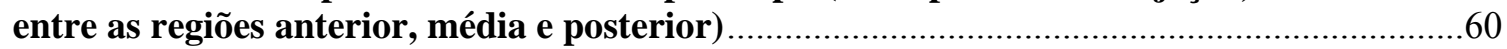

5.4.3 Análise do lado ipsilateral à injeção de Pilo, região posterior........................................62

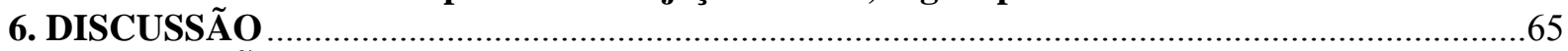

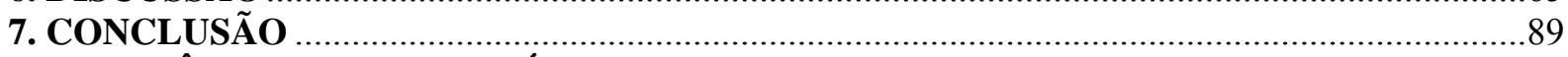

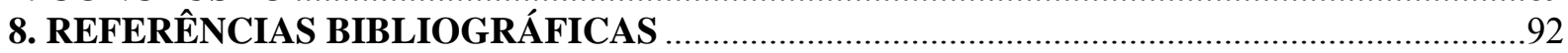


1. MARCO TEÓRICO 


\section{MARCO TEÓRICO}

\subsection{Epilepsia do Lobo Temporal}

A epilepsia é um distúrbio neurológico caracterizado por crises espontâneas e recorrentes causada por descargas sincrônicas e excessivas em uma população neuronal (WASTERLAIN et al., 1993). Os padrões de disparos anormais em neurônios são as principais causas das crises epilépticas (MCNAMARA, 1994). De acordo com a nova classificação da Liga Internacional contra Epilepsia (International League Against Epilepsy, ILAE), podemos classificar as crises epilépticas como (1) generalizadas, que rapidamente recrutam redes neurais bilateralmente distribuídas, ou (2) focais que se originam em redes neurais limitadas a um hemisfério cerebral (BERG et al., 2010).

A epilepsia do lobo temporal (ELT), a mais comum forma de epilepsia em adultos (ENGEL et al., 1989), é caracterizada clinicamente por um progressivo desenvolvimento de crises recorrentes com foco no lobo temporal (ENGEL, 1996; ENGEL et al., 1989). Na maioria dos pacientes, as lesões e alterações funcionais da ELT tem início na infância após um insulto precipitante inicial como convulsão febril, status epilepticus (SE), encefalite ou trauma. A presença de uma alteração preexistente pode facilitar o desenvolvimento da ELT (ARZIMANOGLOU et al., 2002) e esta condição pode ser devido a uma predisposição genética, congênita ou adquirida após um insulto (ENGEL, 1996). De fato, sabe-se que, nas ELT, a formação hipocampal é a estrutura mais danificada e exibe uma perda neuronial seletiva e gliose que caracterizam a chamada esclerose hipocampal. Do ponto de vista anatomopatológico, tais perdas são visíveis em CA1, présubiculum e na região do hilo, com

relativa preservação das células em CA2, subiculum e giro denteado (BABB et al., 1984a). É observada também plasticidade axonial com brotamento de fibras musgosas na camada interna do giro denteado (DAVENPORT et al., 1990). Os mecanismos responsáveis pela 
vulnerabilidade seletiva de certas populações neuronais ainda não são entendidos, a ativação de receptores de glutamato pode contribuir para a lesão excitotóxica (NAJM et al., 1998).Mecanismos protetores endógenos têm sido propostos em resposta a estímulos potencialmente deletérios às células e, apesar da literatura apresentar dados relacionados às respostas celulares, pouco se conhece a respeito do envolvimento de cascatas de sinalização com insultos epileptogênicos no sistema nervoso. A enzima fosfatidilinositol-3-cinase (PI3K) está envolvida na ativação da cascata de sinalização intracelular de Akt. A Akt é uma proteína cinase específica de serina/treonina cuja forma ativa proporciona um controle no crescimento e proliferação celular, bem como um "sinal de sobrevivência", protegendo células da apoptose (LUO et al., 2003). O estudo da ação de inibidores da PI3K em modelos de epilepsia pode fornecer dados sobre o envolvimento da Akt em sinais neuroprotetores e possibilitar o desenvolvimento de novas terapias para injúrias cerebrais baseadas na ativação de processos neuroprotetores.

\subsection{Modelos experimentais de Epilepsia do Lobo Temporal}

O uso de modelos animais para o estudo de distúrbios neurológicos é importante para o entendimento dos mecanismos fisiopatológicos das epilepsias que não podem ser estudados diretamente em seres humano. Porém, para ser eficiente em desvendar os mecanismos envolvidos nestas doenças, os modelos animais devem reproduzir muito bem as características desta doença (BERTRAM, 2007). Um modelo experimental de Epilepsia é a indução de status epilepticus (SE) em animais de experimentação que consiste em um período de crises convulsivas sustentadas.

A administração sistêmica do agonista muscarínico colinérgico, Pilocarpina (Pilo), é muito utilizada em modelos experimentais de $S E$, especialmente no estudo da ELT, pois induz mudanças anatômicas e comportamentais em ratos muito semelhantes às observadas em 
humanos (LEITE et al., 1990), com perda celular hipocampal principalmente nas regiões do hilo, CA1 e CA3, brotamento das fibras musgosas, crises espontâneas recorrentes (CERs) e dispersão celular na camada granular (MELLO et al., 1993). No modelo de $S E$ induzido por Pilo, os animais apresentam crises recorrentes espontâneas (CREs) seguido um período latente após o SE (CAVALHEIRO et al., 1991; TURSKI, L. et al., 1989).Além disso, a administração de Pilo tem sido importante para a compreensão dos mecanismos desencadeadores de morte neuronial após crises convulsivas, além dos consequentes prejuízos em aprendizagem (LEITE et al., 1990; LEITE e CAVALHEIRO, 1995). Alterações neuropatológicas, como perda neuronial em vários subcampos hipocampais, reorganização de fibras musgosas na camada molecular da fascia dentata, também são observadas neste modelo (LEITE e CAVALHEIRO, 1995; MELLO et al., 1993; MELLO e COVOLAN, 1996).

O $S E$ convulsivo em animais tem sido um importante método experimental para elucidação da função da atividade sináptica excitatória na morte neuronal associada às crises (MELDRUM et al., 1973; OLNEY et al., 1974). Estudos pioneiros mostram que crises convulsivas prolongadas produzem danos cerebrais mesmo quando fatores sistêmicos tais como a glicemia, oxigenação do sangue, temperatura estão em níveis normais (MELDRUM et al., 1973).

Apesar de reproduzir a ELT de maneira consistente, altas doses de Pilo (acima de 300 mg/kg) são necessárias para indução de $S E$ (CAVALHEIRO et al., 1991; CLIFFORD et al., 1987; LEITE et al., 1990) e estão associadas a altas taxas de mortalidade (CLIFFORD et al., 1987; TURSKI, L. et al., 1989). Furtado e colaboradores (2002) mostraram que a injeção intra-hipocampal de Pilocarpina, em ratos, reproduz o mesmo quadro fisiopatológico observado após injeção intraperitoneal, porém, com grande redução da mortalidade dos animais. Além disso, esta estratégia nos permite reduzir a dose injetada, assim como controlar a área-alvo a ser acometida inicialmente. 


\subsection{Aspectos moleculares da morte neuronal}

A identificação de moléculas, cuja expressão está alterada na condição epiléptica, é de fundamental importância, tanto para entender as vias associadas aos mecanismos de epileptogênese, quanto para compreender as alterações secundárias às crises recorrentes (GITAI et al., 2008).

Muitos estudos têm focado a expressão diferencial de genes envolvidos com os mecanismos de morte celular por apoptose. Tem sido demonstrado que genes que participam diretamente deste processo apresentam expressão alterada no hipocampo. Tais genes agem na via apoptótica extrínseca (caspases 2 e 8, FADD) (HENSHALL et al., 2001) ou intrínseca (HENSHALL e SIMON, 2005). Nesta última, destacam-se as caspases efetoras (caspases 3 e 6), famílias das proteínas bcl-2 pró-apoptóticas (bad, bax, bim, bid) e antiapoptóticas (bcl-2, bcl-x, bcl-w).

No estudo de Henshall e colaboradores (2002), constatou-se que a Akt fosforilada pode proteger neurônios da morte celular em diferentes áreas do cérebro. A importância desta via foi comprovada através da utilização de um inibidor de PI3K, que inibe a cascata da Akt e agrava a morte celular cortical.

\subsection{Cascata de sinalização da proteína Akt/PKB}

\subsubsection{Caracterização histórica da Akt/PKB}

Proteínas cinases fazem parte de uma rede complexa de proteínas que constituem as células; elas atuam como "sensores" no controle e propagação de informações ao meio exterior celular e na organização do seu próprio sistema. A Akt é um exemplo de cinase específica que se encontra inativa em células em repouso.

As pesquisas envolvendo a Akt foram iniciadas quando da descoberta de um vírus mutante de leucemia em camundongos (STAAL et al., 1977). Esse vírus, encontrado em alta 
incidência em linfomas espontâneos com a capacidade de formar focos malignos em linhagens celulares, foi chamado de Akt8. Staal e colaboradores (1977) descobriram e comprovaram que esse retrovírus expressava uma sequência e uma capacidade oncogênica para o desenvolvimento de linfomas de timo.

Em 1991, estudos realizados por Coffer e Woodgett, Bellacosa, Jones e colaboradores identificaram os genes correspondentes a Akt e descreveram o clone Akt1 ou isoforma PKB $\alpha$ (ORCY et al., 2008). A semelhança entre a sequência da Akt e a das proteínas da família cinase A e C (PKA e PKC) foi identificada por Jones e colaboradores, sendo denominada Rac, enquanto Cooffer e Woodget a nomearam de PKB (proteína cinase B) e Bellacosa e colaboradores a chamaram de Akt. As três denominações são encontradas na literatura, mas o termo Akt/PKB adquiriu um consenso maior entre os pesquisadores (ORCY et al., 2008).

A segunda isoforma da Akt/PKB foi descrita ainda em 1991 por Jones e colaboradores, sendo, atualmente, conhecidas três diferentes isoformas em mamíferos, denominadas como Akt1/PKB $\alpha, A k t 2 / \mathrm{PKB} \beta$ e Akt3/PKB $\gamma$ (ORCY et al., 2008). Estas isoformas apresentam $85 \%$ de similaridade em suas sequências e arranjos estruturais semelhantes, divididos em: domínio N-terminal PH (pleckstrin homology), essencial para a ligação de proteínas em lipídios como o fosfoinositol-trifosfato (PIP3); um fosfolipídeo de membrana plasmática (BRAZIL e HEMMINGS, 2001; BRAZIL et al., 2002; FAYARD, E. et al., 2005b); um domínio central cinase; e um domínio regulatório C-terminal que contém uma região hidrofóbica (HM-hydrophobic motif) (ORCY et al., 2008). Todas as três isoformas de Akt/PKB possuem resíduos conservados de serina e treonina (T308 e S473 em Akt1/PKB) que, juntos com o domínio $\mathrm{PH}$, são críticos para a ativação de PKB.

A estrutura da Akt é bem conservada entre as espécies (ORCY et al., 2008), embora os níveis de expressão variem entre os tecidos, sendo a Akt1/PKB $\alpha$ a isoforma mais predominante. Um padrão peculiar de $\mathrm{Akt} 1 / \mathrm{PKB} \alpha$ foi detectado no cérebro, onde neurônios 
em regeneração apresentam aumento de seus níveis (KANDEL e HAY, 1999; OWADA et al., 1997). A expressão mais alta de Akt2/PKB $\beta$ foi observada em tecidos responsivos à insulina (músculo esquelético, coração, fígado e rim), sugerindo que esta isoforma é importante para a sinalização da insulina, ao passo que as duas outras isoformas Akt3/PKB $\gamma$ mostram uma maior restrição do padrão de expressão.

\subsubsection{Funções fisiológicas da Akt/PKB}

O papel fisiológico das isoformas de Akt tem sido demonstrado por meio de manipulação genética em camundongos, os quais propiciam o estudo das funções da Akt/PKB in vivo. Vários camundongos transgênicos expressando Akt, sob condições controles, têm sido produzidos em laboratório, permitindo, assim, constatar que um dos maiores papéis da Akt está relacionado com o crescimento celular: o aumento da expressão da Akt/PKB causa hipertrofia e aumento da contratilidade cardíaca, progressão de tumores como o linfoma de células $\mathrm{T}$ ou neoplasia prostática, hipertrofia, hiperplasia e hiperinsulinemia em células $\beta$ pancreáticas e desenvolvimentos das glândulas mamárias durante a gravidez (ORCY et al., 2008). Em camundongos knockout do gene Akt1/PKBa, foi possível identificar que esta isoforma tem um papel significativo sobre a mortalidade neonatal, bem como retardo no desenvolvimento embrionário devido a defeitos no desenvolvimento placentário. Ao passo que no uso da técnica knockout do gene Akt2/PKB $\beta$, os camundongos apresentaram resistência importante à insulina, similar aos sintomas de uma diabetes mellitus tipo 2, acompanhada de retardo de crescimento e perda de tecido adiposo idade-dependente (ORCY et al., 2008). Já para a expressão da terceira isoforma, Akt3/PKB $\gamma$, os camundongos knockout apresentaram uma redução de 20 a $25 \%$ do tamanho e do peso da massa cerebral, o que se deve a uma diminuição do tamanho e número de células nesse tecido (FAYARD, E. et al., 2005b). 


\subsubsection{Sinalização da via upstream da Akt/PKB}

\subsubsection{Ativação de fosfatidilinositol 3-cinase (PI3K)}

A função da cascata de sinalização da Akt ficou evidente após o estudo da PI3K. Esta enzima é ativada por receptores de tirosina cinase (CARPENTER et al., 1990) que sofrem autofosforilação após sua ligação a fatores de crescimento, como por exemplo, a insulina (ORCY et al., 2008).

As enzimas fosfatidilinositol 3-cinases são membros de uma família bem conservada e única de cinases intracelulares que fosforilam o grupo 3'-hidroxila de fosfatidilinositol e fosfoinositídeos (ORCY et al., 2008). Essas enzimas encontradas em mamíferos são classificadas em classes I, II e III, sendo que a classe I é dividida em subclasses A e B. As diferentes classes têm funções distintas na sinalização celular e levam à ativação de várias vias de sinalização que regulam o metabolismo, sobrevivência, crescimento e diferenciação celular, bem como o tráfego de vesículas intracelulares (ORCY et al., 2008). As PI3K classe IA são ativadas por receptores de tirosina cinases (RTKs), pois possuem uma subunidade p85 regulatória essencial para essa interação, enquanto as da classe IB são ativadas por receptores acoplados à proteína G que não possuem essa subunidade. É descrito somente para PI3K da classe I, a capacidade de fosforilar fosfatidilinositol-bi-fosfato (PIP2) e produzir fosfatidilinositol-tri-fosfato (PIP3), ainda não descrito para as demais classes de PI3K que diferem quanto a capacidade de fosforilar os lipídeos das membranas (ORCY et al., 2008).

\subsubsection{Inibidores da ativação de PI3K-Akt/PKB}

A ativação de PI3K desencadeada por autofosforilação pode ser bloqueada pelas substâncias Wortmanina e LY294002 considerados importantes na avaliação dos eventos subsequentes (do inglês, downstream "reactions") desta enzima (VLAHOS et al., 1994). Portanto, a utilização de inibidores seletivos e não seletivos são ferramentas úteis para a 
caracterização de proteínas-alvo, particularmente quando os alvos são pivôs em cascatas de sinalização (UI et al., 1995).

\section{a) Wortmanina}

A Wortmanina, um metabólito fúngico descoberto em 1987, foi o primeiro a inibir uma resposta celular após estimulação de receptor in vitro. A sua utilização possibilita a convergência entre dois importantes sistemas de sinalização celular: o de receptor de proteína G e os de receptores de proteína cinase (UI et al., 1995).

Em concentração nanomolar, a Wortmanina é considerada um inibidor potente e específico de fosfatidilinositol 3-cinase, e tem sido usada amplamente para demonstrar o papel de PI3K em diversos processos de transdução de sinal. O inibidor é permeável à célula, apresentando uma dose de inibição $\left(\mathrm{IC}_{50} \mathrm{~s}\right)$ de 1,8 a 4,0 $\mathrm{nM}$ e foi considerado potente em inibir e não apresentar efeitos em outras moléculas envolvidas com a sinalização, como por exemplo a proteína cinase $\mathrm{C}(\mathrm{PKC})$ calmodulina dependente, $\mathrm{AMP}$ cíclico $\left(\mathrm{AMP}_{\mathrm{c}}\right)$, proteínamitógeno ativada (43), p70 ${ }^{\mathrm{S} 6 \mathrm{k}}$, sem influência em Ptdlns 4-P e Ptdlns(4,5) $\mathrm{P}_{2}$ (WYMANN et al., 1996).

Embora ainda não seja completamente compreendido como a inativação da PI3K possa afetar as respostas celulares subseqüentes, sabe-se que as atividades enzimáticas são afetadas pela presença de inibidores ou são moduladas por Ptdlns $(3,4,5) \mathrm{P} 3$. A via de proteínas cinases GSK 3 (sintase 3 de glicogênio), $\mathrm{p} 70^{\mathrm{S} 6 \mathrm{~K}}$, fosfolipase D, proteína Rac ligada a GTP, isoformas PKC $\delta, \varepsilon, \tau, \zeta$ e proteína cinase Akt-c/PKB são propostas como dependentes de PI3K (WYMANN et al., 1996).

No estudo de Dash e colaboradores (2002), utilizando infusão intra-hipocampal de Wortmanina $\mathrm{IC}_{50}$ de 20-50 nM em ratos pós-treino, foi evidenciado que a inibição de PI3K promoveu um armazenamento de memória a longo prazo. Este estudo observado com a 
injeção bilateral intra-hipocampal, revela estruturas intimamente envolvidas nas tarefas do labirinto aquático de Morris, sugeriu que a inibição da cascata de PI3K resultou em aumento da consolidação da memória espacial.

Recentemente, Ozaita e colaboradores (2007) demonstraram que o uso de canabinoide, como o delta-9-tetra-hidrocanabinol (THC) desempenha um papel neuroprotetor por intermédio da ativação da via de Akt/PI3K. Com a administração de Wortmanina a fosforilação de Akt, induzida por THC no hipocampo, foi inibida através da inativação de PI3K e assim se confirmou o papel significativo da PI3K nos efeitos de THC na Akt.

Dessa forma, os estudos têm demonstrado que a Wortmanina pode ser considerada um importante agente para a investigação dos efeitos da atividade da fosfatidilinositol-3-cinase.

\section{b) LY294002}

O LY294002, também conhecido como 2-(4morpholinyl)-8-phenyl-4H-1-benzopyran4-one, demonstrou ser um inibidor seletivo da enzima PI3K in vivo. Quando utilizado na dose inibitória de $50 \%\left(\mathrm{IC}_{50} \mathrm{~S}=0,43 \mu \mathrm{g} / \mathrm{ml} ; 1,40 \mu \mathrm{M}\right)$, tende a eliminar a atividade desta enzima em neutrófilos humanos, bem como em células musculares lisas de segmento aórtico de coelhos. Entretanto, esta inibição não é identificada em outros lipídios e proteínas cinases, tais como PI4K, PKC, MAPK ou $c$-Src (VLAHOS et al., 1994).

Segundo Vlahost e colaboradores (1994), o LY294002 também se comporta como um inibidor competitivo para o sítio de ligação do ATP na enzima PI3K. Para esse estudo, foi realizada uma prova cinética utilizando várias concentrações de ATP e concentrações aumentadas do inibidor. Sabe-se que LY294002 é capaz de inibir PI3K independente do estado de fosforilação desta enzima.

Em um ensaio realizado por Brunn e colaboradores (1996), a atividade autocinase de imunopurificados de mTOR recombinante foi sensível a LY294002 em concentração 
aproximada $\mathrm{IC}_{50} \mathrm{~S}$ de $5 \mu \mathrm{M}$. Deste modo, o LY294002 é efetivamente alvo do domínio catalítico de mTOR em concentração similar $(\sim 3 \mu \mathrm{M})$ necessária para a inibição de PI3K em mamíferos.

Um estudo interessante, realizado por Henshall e colaboradores (2002), demonstrou que a injeção intracerebroventricular de 100 nmol de LY294002, (114 \pm 50$)$ sec., ocasionava um efeito protetor da Akt, que foi limitado ao córtex cerebral de animais submetidos a crises pelo ácido caínico. As injúrias observadas nos animais submetidos a crises não diferiram daqueles animais controles tratados somente com o veículo. Entretanto, foi identificado um número aumentado de células corticais positivas para TUNEL em ratos com crises, quando comparado aos animais controles. Por fim, observou-se que a administração de LY294002, inibidor de PI3K e, possivelmente, um ativador upstream de Akt, agravou a apoptose cortical depois das crises.

\subsubsection{Sítio de Treonina (T308) e Serina (S473) da Akt/PKB}

A ativação da Akt in vivo é precedida por um aumento na fosforilação de resíduos de Serina 473 (S473) e Treonina 308 (T308). Quando esses dois aminoácidos são mutados para resíduos não fosforiláveis, a ativação da cinase é eliminada (KANDEL e HAY, 1999). A sequência circundante para esses dois resíduos fosforilados é muito diferente, sugerindo que duas diferentes cinases estão, provavelmente, envolvidas na fosforilação desses sítios, a qual ocorre independentemente e ocasiona forte ativação da atividade de Akt/PKB (DOWNWARD, 1998). 


\section{a) Fosforilação do resíduo de Treonina 308}

Para que ocorra a fosforilação do resíduo Treonina 308 é necessário que a Akt, por intermédio do seu domínio PH, ligue-se aos fosfoinositídeos da membrana. A presença de PDK1 (3-phosphoinositide-dependent protein kinase-1) é indispensável para o mecanismo, sendo observada uma quantidade aumentada desta proteína nesse processo (ORCY et al., 2008). Assim, tem sido indicado que produtos de ligação Ptdlns (3,4)P2 e Ptdlns (3,4,5)P3 se ligam ao domínio PH de Akt causando a sua translocação para a membrana plasmática e permitindo, dessa forma, maior interação com PDK1.A fosforilação de T308 é importante para ativação da cascata, uma vez que a atividade da Akt é potencializada em aproximadamente 100 vezes (ORCY et al., 2008).

É interessante mencionar que um grande número de questões relacionadas às funções da PDK1 ainda permanece em aberto. Uma dessas questões está relacionada com o nível de concentração da PDK1 na membrana plasmática (DOWNWARD, 1998).

\section{b) Fosforilação do resíduo de Serina 473}

$\mathrm{Na}$ literatura, ainda não há consenso sobre qual seria a cinase responsável pela fosforilação da Akt no domínio regulatório Serina 473 (FAYARD, E. et al., 2005b); uma série de diferentes candidatos tem sido proposta, dentre os quais podemos citar a cinase PDK2, mecanismos de autofosforilação da Akt (TOKER e NEWTON, 2000), MAPKAPK2 (mitogen activated protein kinase activated protein kinase 2) (ALESSI et al., 1996), ILK1 (integrinlinked kinase 1) (PERSAD et al., 2001), ATM (ataxia telangiecatsia mutant) (VINIEGRA et al., 2005), DNA-PK (DNA protein kinase) (FENG et al., 2004), PKC $\beta$ II (protein kinase C $\beta I I)$, PDK1 (BALENDRAN et al., 1999) e, mais recentemente, o mTOR complex TORC2 (rapamycim-insensitive) (SARBASSOV et al., 2005). Por outro lado, é provável que condições fisiológicas celulares estejam favorecendo a ação desta ou daquela enzima para a 
fosforilação do sítio de S473, levando, então, a participação ativa de mais de uma enzima nesse processo. Desta forma, é importante estudar os mecanismos e interferentes neste processo, pois é sabido que a fosforilação do sítio S473 é um passo chave na ativação da Akt, permitindo que esta se re-estruture para um estado mais estável e transite da membrana plasmática para o núcleo celular ou citoplasma (ORCY et al., 2008).

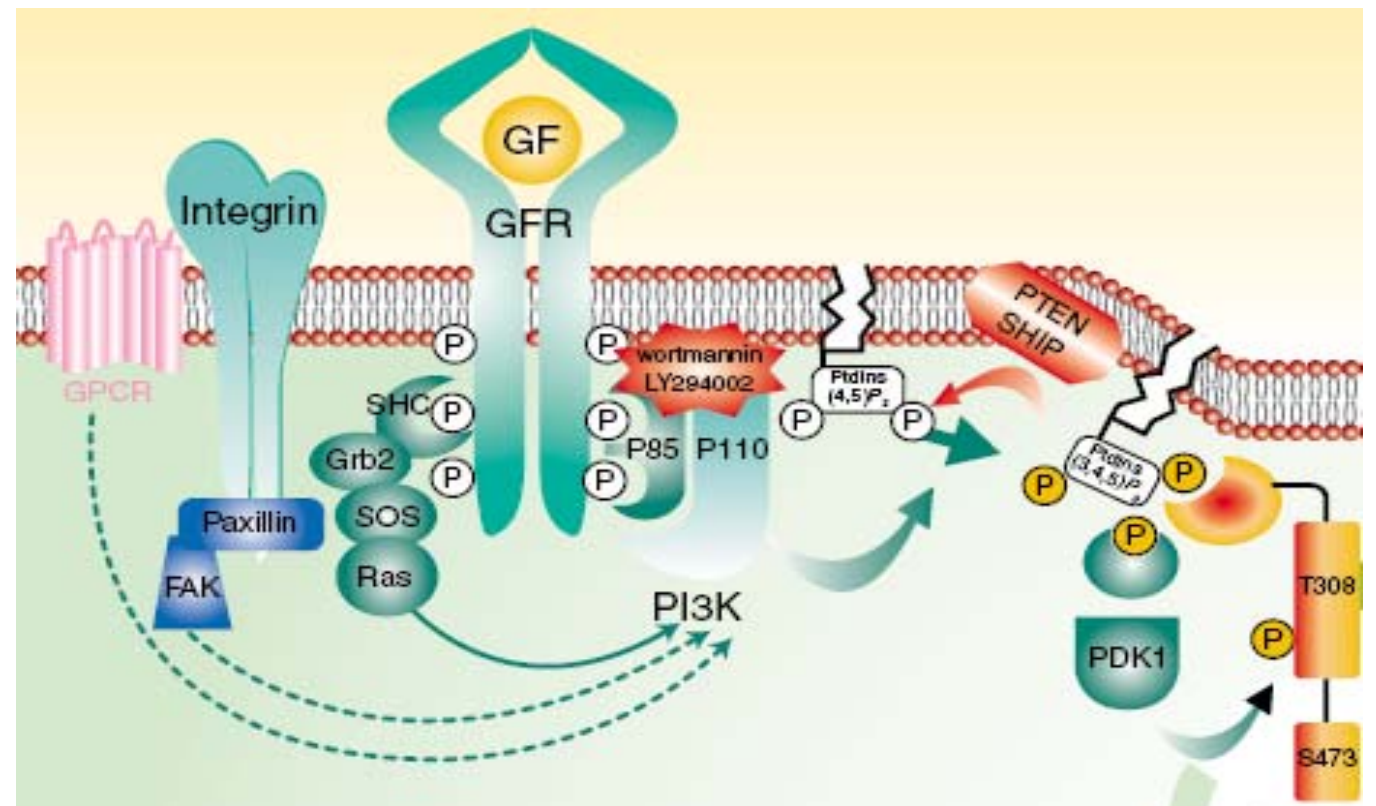

Figura 1. Sítio de ligação dos inibidores de PI3K: Wortmanina e LY294002 e fosforilação da Akt/PKB nos resíduos de T308 e S473; FAK (cinase de adesão focal), GFR (receptor-fator de crescimento), Grb2 (receptor fator de crescimento ligado a proteína), PDK1 (proteína cinase dependente de fosfoinositídeo1), PI3K (fosfatidilinositol-3-cinase), Ptdlns(4,5) $\mathrm{P}_{2}$ (Fosfatidilinositol 4,5-bi-fosfato), Ptdlns(3,4,5) $\mathrm{P}_{2}$ (Fosfatidilinositol 3,4,5-tri-fosfato), P85 e P110 (subunidades de PI3K), Ras (Rac sarcoma oncogene), SOS (son of sevenless), SHC (Src homology 2 domain-containg transforming protein 1), S473 (serina 473), T308 (treonina 308).Modificada de Fayard et al. (2005b).

\subsubsection{Sinalização da via downstream da Akt/PKB}

Para a compreensão do papel da Akt, alguns esforços têm sido realizados no sentido de identificar os substratos fisiológicos que participam no processo da fosforilação da cascata e que regulam a função de muitas proteínas celulares envolvidas no metabolismo, sobrevivência/apoptose, diferenciação e proliferação celular (FAYARD, E. et al., 2005b). Muitos substratos de PKB contêm uma sequência mínima, denominada de R-X-R-X-X-S/TB, e que é indispensável para a caracterização de um substrato pela Akt. Nesta sequência, o X 
representa qualquer aminoácido, $\mathrm{B}$ representa resíduos hidrofóbicos, $\mathrm{R}$ representa a arginina na posição -5 e -3 e $\mathrm{S} / \mathrm{T}$ que são os sítios de fosforilação $\mathrm{S}$ como Serina e $\mathrm{T}$ como Treonina (ORCY et al., 2008).

Relatos na literatura têm indicado que cerca de 100 substratos não redundantes da Akt já foram descritos, sendo 18 desses com uma sequência que traduz as funções desempenhadas pela Akt (MANNING e CANTLEY, 2007). Esta revisão levou em consideração alterações no grau de fosforilação com aumento e diminuição da Akt, fosforilação do sítio R-X-R-X-X-S/T in vitro e bloqueio da cascata com a utilização de inibidores de PI3K: Wortmanina e LY294002 (ORCY et al., 2008).

\subsubsection{Regulação da sobrevivência e proliferação celular estimulada pela}

\section{Akt/PKB}

A cascata de sinalização da Akt é conhecida como uma das mais importantes vias na regulação da sobrevivência celular e sua ativação permite que células com sinal de sobrevivência possam opor-se a estímulos apoptóticos. Dados recentes da literatura elucidam o importante papel de sinalização da Akt na sobrevivência celular de vários tipos de cânceres (SONG et al., 2005). A Akt tem efeito direto na via da apoptose celular, ligando-se a um membro da família de Bcl-2, chamado Bad (pro apoptotic Bcl-2 related protein). A proteína Bad se liga a Bcl-2 e Bcl-x, inibindo o efeito antiapoptótico destas proteínas. Entretanto, quando a Akt se liga a Bad, ocorre fosforilação do resíduo Ser 136 que, por sua vez, inativao. Sendo Bad liberado do complexo formado com Bcl-2 e Bcl-x, isso permitirá que essas proteínas desempenhem maior atividade quanto às funções antiapoptóticas (ORCY et al., 2008). Segundo Song e colaboradores (2005), a Akt pode participar da fosforilaração do sítio Serina 196 da Caspase-9 humana, inativando-a. Neste caso, esta proteína, conhecida como iniciadora e efetora da apoptose, teria o seu efeito reduzido. 
Estudos recentes têm demonstrado que alguns substratos para a Akt são capazes de regular a sobrevivência celular por meio de fatores transcricionais que são responsáveis por genes pró e antiapoptóticos. Entre essas proteínas está a família Forkhead (FoxO ou FH) constituída de quatro isoformas (FoxO1, FoxO2, FoxO3A e FoxO4) e que são alvos da fosforilação de Akt, o que inibe a transcrição de seus fatores pró-apoptóticos (ORCY et al., 2008). O Nf-kB (transcription factor nuclear factor-kB) é um importante regulador da resposta imune e a sua desregulação implica no desenvolvimento de doenças autoimunes e tipos de cânceres. A sua ativação é importante para fosforilação do complexo IkB cinase (IKK) que degrada o inibidor ligado a Nf-kB, chamado IkB, e, por sua vez, o NF-kB livre se transloca para o núcleo e ativa a transcrição de genes pró-sobrevivência celular (ORCY et al., 2008), incluindo Bcl-x, caspases inibitórias e c-Myb (SONG et al., 2005). O Mdm2 (murine doublé minute 2) é um oncogene induzido por p-53. O p-53 é um importante regulador da morte celular induzida por estresse, principalmente naquelas situações em que há envolvimento de danos ao DNA. No processo, a Akt fosforila Mdm2 nos resíduos de Serina 166 e Serina 186 resultando em degradação e inativação do p-53 e inibição da morte celular (ORCY et al., 2008). A proteína CREB sofre fosforilação de Akt no resíduo de Serina 133 o que promove a indução de genes antiapoptóticos, tais como bcl-e e mcl-1.

A diminuição da oferta de fatores de crescimento celular pode levar a uma diminuição da habilidade de utilizar nutrientes, resultando em depleção de ATP intracelular. A Akt permitiria a continuidade da captação celular de glicose e aminoácidos, prevenindo a indução de fatores apoptóticos que ocorrem nessa situação. Sabe-se que a GSK3 estaria envolvida em outras vias de sinalização, funcionando como um fator de proteção contra a apoptose (SONG et al., 2005). 


\subsubsection{Regulação do crescimento celular estimulado pela Akt/ PKB}

A cascata de sinalização da Akt também está envolvida com o crescimento e aumento do volume celular, algo muito comum em células tumorais. A via mTOR que regula diretamente a síntese de proteínas, metabolismo e ciclo celular é a via apontada como a responsável pelo crescimento de células. Sabe-se que em algumas condições celulares onde existe a escassez de nutrientes e supressores tumorais como o TSC1 (tuberous sclerosis complex 1), conhecido como hamartin, e o TSC2 (tuberous sclerosis complex 2), conhecido como tuberin, e LKB1 (serine/threonine kinase 1), atenuam a sinalização de mTOR. A Akt ativa mTORC1 através da fosforilação e inibição do TSC2 e do PRAS40 (proline-rich Akt substract of $40 \mathrm{kDa}$ ) que inibe o mTORC1. O aumento celular e da síntese protéica, bem como os processos anabólicos dos quais participam mTORC1 ainda são desconhecidos, segundo relatos da própria literatura (ORCY et al., 2008).

\subsubsection{Regulação do metabolismo e captação de glicose pela Akt/PKB}

A regulação do metabolismo celular é uma das principais funções físiológicas desenvolvidas pela Akt. A presença de níveis elevados de insulina na circulação sanguínea faz com que a GSK3 (glicogênio sintetase cinase) seja inibida pela fosforilação da Akt, resultando em um estoque de glicose e síntese de glicogênio. O papel da GSK3 que, na verdade, é inibir a síntese de glicogênio, quando inativada pela Akt tem a sua função revertida, permitindo que o excesso de glicose se converta em glicogênio (ORCY et al., 2008). Sabe-se que a isoforma Akt2 está envolvida em resposta à insulina e atua como transportadora de glicose do tipo 4 (GLUT4) e que AS160 e Rab-GAP têm emergido como alvos diretos da Akt neste processo.

A regulação do metabolismo de lipídios é outra função importante desempenhada pela Akt e consiste na inibição e fosforilação de GSK3. A fosforilação de substratos pela GSK3 é 
alvo frequente de degradação proteossômica e alguns fatores, tais como o SREBPs (sterol regulatory element bind protein), aumentam a expressão de genes envolvidos na biossíntese de lipídeos. Assim, a Akt promove a inibição da GSK3 e, ao mesmo tempo, estabiliza a SREBPs, aumentando a produção de lipídeos (ORCY et al., 2008).

\subsubsection{Regulação da angiogênese pela Akt/PKB}

A Akt/PKB desempenha um papel importante na angiogênese fisiológica e patológica em células endoteliais e produtoras de sinal angiogênico, tais como células tumorais. Em células endoteliais, a via da Akt/PI3K é ativada por um fator de crescimento endotelial e a fosforilação dos alvos da Akt contribuem para a sobrevivência, crescimento e proliferação celular. Além disso, a Akt ativa a eNOS (sintase de óxido nítrico) por intermédio da fosforilação do resíduo de Serina 1177. A liberação de óxido nítrico pela eNOS pode estimular a vasodilatação, remodelagem vascular e a angiogênese (ORCY et al., 2008). 
2. JUSTIFICATIVA 


\section{JUSTIFICATIVA}

Considerando a participação da Akt em mecanismos de sobrevivência, proliferação e crescimento celular, bem como em processos do metabolismo celular, levantamos a hipótese de que a Akt pudesse estar envolvida em respostas frente a insultos no sistema nervoso. Assim, o estudo da ação de inibidores da enzima PI3K poderia fornecer informações relevantes sobre a participação destes mecanismos no contexto de um dano cerebral decorrente de um insulto excitotóxico, como o status epilepticus. 
3. OBJETIVOS 


\section{OBJETIVOS}

\section{Gerais}

Avaliar o efeito do $S E$ por injeção intra-hipocampal de Pilocarpina na ativação da Akt, bem como os efeitos do bloqueio desta cascata sobre as alterações patológicas observadas no hipocampo de ratos na fase aguda pós-SE.

\section{Específicos}

a) Avaliar o efeito do $S E$ induzido por injeção intra-hipocampal de Pilocarpina sobre a ativação da proteína Akt no hipocampo, bem como analisar os seus aspectos comportamentais.

b) Avaliar o efeito do pré-tratamento com inibidores da ativação da Akt (Wortmanina e LY294002) em animais submetidos a SE por injeção intra-hipocampal de Pilocarpina sobre a morte neuronial, astrogliose hipocampal e a expressão da proteína Akt. 
4. METODOLOGIA 


\section{METODOLOGIA}

\subsection{Animais}

No início dos experimentos, foram utilizados ratos machos da espécie Wistar, idade de dois meses, peso entre 260 e $300 \mathrm{~g}$ e todos provenientes do Biotério Central da Faculdade de Medicina de Ribeirão Preto. Os animais tiveram livre acesso a água e comida e foram mantidos em ciclo claro/escuro a cada 12 horas com temperatura local mantida em $22 \pm 2^{\circ} \mathrm{C}$. Todos os procedimentos foram realizados de acordo com os princípios éticos da experimentação com animais adotados pelo colégio Brasileiro de Experimentação Animal (COBEA) e com aprovação da Comissão de Ética em Experimentação Animal da FMRP-USP (CETEA n¹34/2008).

\subsection{Cirurgia esteriotáxica para implantação bilateral de cânulas}

Os animais foram anestesiados com injeção intraperitoneal (ip) de ketamina $^{1}$ (100 $\mathrm{mg} / \mathrm{kg})$ e xilazina ${ }^{2}(10 \mathrm{mg} / \mathrm{kg})$, seguido de uma dose de pentabiótico ${ }^{3}$ veterinário de amplo espectro $(0,2 \mathrm{ml})$ administrados por via intramuscular. Os animais foram submetidos à tricotomia do escalpo e seu crânio fixado no estereotáxico (KOPF instruments, EUA); em seguida, foi realizada a assepsia do escalpo com álcool iodado ${ }^{4}$ e administrada e injeção subcutânea de anestésico $^{5}$ com vasoconstritor no local da incisão para diminuição do sangramento. Foi realizada uma incisão de $2 \mathrm{~cm}$ no plano sagital permitindo, assim, a exposição e limpeza da superfície do crânio.

\footnotetext{
1 Ketamina Agener 10\%; Agener União

${ }^{2}$ Dopaser $10 \mathrm{ml}$; Hertape Calier

${ }^{3}$ Pentabiótico veterinário contendo 240.000 UI das Penicilinas e $100 \mathrm{mg}$ de Estreptomicina e Diidroestreptomicina por $\mathrm{mL}$ ( $25 \mathrm{ml}$ ); Forte Dodge Sacede Animal

${ }^{4}$ P.V.P.I Povidine; Rioquímica

${ }^{5}$ Lidocaína 2\% e epinefrina 1:80.000 em $\mathrm{NaCl} 0,15 \mathrm{M}$
} 
Tomando-se o bregma como referência, e com base nas coordenadas ântero-posterior: +5,5 mm; médio-lateral: +4,5/-4,5 mm; dorso-ventral: -2,1 mm; (PAXINOS e WATSON, 1986), foram implantadas, bilateralmente, duas cânulas de $12 \mathrm{~mm}$ na área cerebral dos animais, uma do lado esquerdo e outro do lado direito do hipocampo. Após isto, foram feitos mais dois orifícios no crânio para inserção de dois micro-parafusos para fixação do capacete com cimento acrílico. Ao final da cirurgia, os animais receberam outra dose de pentabiótico $(0,2 \mathrm{ml} \mathrm{im})$ e permaneceram em caixas individuais por 5 dias para recuperação antes do início do tratamento.

\subsection{Protocolo experimental}

Os animais foram divididos em Grupo Controle e Grupo Tratado de acordo com a tabela 1 .

Tabela 1: Protocolo experimental

\begin{tabular}{|c|c|c|c|c|c|c|c|}
\hline \multirow{2}{*}{\multicolumn{2}{|c|}{ Grupo }} & \multirow{2}{*}{$\begin{array}{c}\text { Cirurgia } \\
\text { canula }\end{array}$} & \multicolumn{2}{|c|}{ Injeção Ipisilateral } & \multicolumn{2}{|c|}{ Injeção Contralateral } & \multirow{2}{*}{$\begin{array}{l}\text { Sobre- } \\
\text { vida }\end{array}$} \\
\hline & & & 60`antes & após & 60 `antes & após & \\
\hline \multirow[t]{2}{*}{ Controle } & $\mathrm{Sal}+\mathrm{Sal}$ & \multirow{5}{*}{$\begin{array}{c}5 \text { dias de } \\
\text { recuperação }\end{array}$} & Sal & Sal & Sal & Sal & \multirow{5}{*}{7 dias } \\
\hline & DMSO+Salina & & DMSO & Sal & Sal & Sal & \\
\hline \multirow{3}{*}{ Tratado } & LY+Pilo & & LY & Pilo & DMSO & Sal & \\
\hline & Wort+Pilo & & Wort & Pilo & DMSO & Sal & \\
\hline & Sal+Pilo & & Sal & Pilo & Sal & Sal & \\
\hline
\end{tabular}

Nos Grupos Tratados foram injetados ipsilateralmente na região posterior do hipocampo e a intervalos de uma hora, as seguintes substâncias: Salina $^{6}$ e Pilocarpina ${ }^{7}$ (grupo Sal+Pilo); LY294002 ${ }^{8}$ e Pilocarpina (LY+Pilo) e Wortmanina ${ }^{9}$ e Pilocarpina (Wort+Pilo). Nos grupos Controles foram injetados: Salina e Salina (grupo Sal+Sal) ou $\mathrm{DMSO}^{10}$ e Salina (grupo DMSO+Sal). Os animais dos grupos LY+Pilo ou Wort+Pilo foram tratados DMSO+Salina no hipocampo contralateral.

\footnotetext{
${ }^{6}$ Salina (cloreto de sódio a $0,9 \%$ ) Samtec Biotecnologia

${ }^{7}$ Pilocarpina Hydrochloride $10 \mathrm{~g}$ (Sigma-Aldrich)

${ }^{8}$ LY294002 (PI3kinase inhibitor) 1,5 mg Cell Signalling

${ }^{9}$ Wortmanina (1232)1 mg Tocris Bioscience

${ }^{10}$ Dimetilsulfóxido (DMSO) 99,9\% Sigma Aldrich
} 
Os animais dos Grupos Tratados foram submetidos à indução de $S E$ pela Pilocarpina, a qual foi interrompido 2 horas após o seu início. Todos os animais foram sacrificados 7 dias após o $S E$, com exceção de um único grupo de animais, Sal+Pilo, sendo sacrificado 24 horas após o insulto. Com o propósito de investigar as alterações celulares e morfológicas, foram realizadas análises de densidade celular em lâminas processadas para a imunohistoquímica para NeuN, a estimativa da intensidade de reação astroglial em lâminas processadas para a Proteína Glial Fibrilar Ácida GFAP (do inglês glial fibrillary acidic protein) e a intensidade de marcação para a proteína Akt nos diferentes níveis de formação hipocampal e na região posterior do hipocampo.

\subsection{Indução de Status Epilepticus por administração de Pilocarpina}

\subsubsection{Grupo Salina+Pilocarpina}

Para a indução do $S E$, os animais receberam inicialmente uma microinjeção intrahipocampal de salina ipsilateral e contralateral, injetada manualmente na velocidade de 1 $\mu 1 /$ min. O sistema de microinjeção consistiu de uma tubulação de polietileno (PE 10) de aproximadamente $30 \mathrm{~cm}$ de comprimento, com a agulha de injeção (gengival 30G curta Injex) de $13 \mathrm{~mm}$ conectada a uma seringa Hamilton $10 \mu 1$.

A indução do $S E$ foi realizada por intermédio da injeção ipsilateral de Pilocarpina $(2,4$ $\mathrm{mg} / \mu \mathrm{l}$ diluída em salina), que foi realizada 60 min após a injeção inicial de salina. $\mathrm{O}$ animal foi imobilizado e a agulha acoplada à seringa foi introduzida na cânula. A Pilocarpina foi injetada manualmente na velocidade de $1 \mu \mathrm{l} / \mathrm{min}$. Os animais passaram a apresentar crises convulsivas sustentadas em torno de 20 e 50 min após a administração de Pilocarpina, sendo estas crises registradas segundo os critérios da escala de Racine, os quais são: 1) movimentos faciais e da boca; 2) balanço da cabeça; 3) clonia das patas anteriores; 4) elevação; 5) elevação e queda (RACINE, 1972). O SE foi interrompido 2 horas após o seu início por 
injeção intraperitoneal de $30 \mathrm{mg} / \mathrm{kg}$ de tiopental sódico ${ }^{11}$. Nos dias subsequentes, os animais foram acompanhados em relação ao seu comportamento. Aqueles animais com maior debilidade foram hidratados e alimentados, individualmente, com ração umedecida e banana até a completa recuperação, quando era constatado que os mesmos se alimentavam espontaneamente.

\subsubsection{Grupo Wortmanina+Pilocarpina}

A Wortmanina (estocada na concentração de 1,17 mM em DMSO 60\%) foi previamente diluída para uma concentração final de 0,25 mM (OZAITA et al., 2007) em DMSO (12,8\%) antes da infusão. Portanto, nosso veículo foi o DMSO (12.8\%) em salina. Estudos anteriores mostraram que a injeção intracerebroventricular de DMSO (25\%) não alterou o padrão de fosforilação de Akt no hipocampo de roedores (OZAITA et al., 2007).

Os animais receberam, inicialmente, uma microinjeção intra-hipocampal de DMSO $(12,8 \%)$ contralateral e Wortmanina $(0,25 \mathrm{mM})$ ipsilateral, ambos injetados numa velocidade de $1 \mu \mathrm{l} / \mathrm{min}$. Após o tempo de 60 minutos, os animais foram novamente tratados, contralateralmente com Salina $(0,9 \%)$ e ipsilateralmente com Pilocarpina $(2,4 \mathrm{mg} / \mu \mathrm{l}$ diluída em salina) ambos no volume de $1 \mu \mathrm{lem}$ um tempo de um minuto.

Aproximadamente no tempo entre 30 e 50 minutos, os animais apresentaram crises autos sustentadas $(S E)$ que foram registradas segundo os estágios correspondentes ao da escala de Racine.

Para maior segurança, a microseringa permaneceu fixada ao sistema por mais 1 minuto para a difusão completa da droga.

\footnotetext{
${ }^{11}$ Tiopental Sódico $1 \mathrm{~g}$ Abbott
} 


\subsubsection{Grupo LY294002+Pilocarpina}

O LY294002 (estocado na concentração de 8,14 mM em DMSO 60\%) foi previamente diluído para uma concentração final de 0,1 mM (CHASSEROT-GOLAZ et al., 1998) em $\operatorname{DMSO}(0,73 \%)$ antes da infusão. Portanto, nosso veículo foi o DMSO $(0,73 \%)$ em salina.

Os animais receberam inicialmente uma microinjeção intra-hipocampal de DMSO (0,73\%) contralateral e LY294002 (0,1 mM) ipsilateral, ambos injetados manualmente numa velocidade de $1 \mu \mathrm{l} / \mathrm{min}$. Após o tempo de 60 minutos os animais foram novamente tratados, contralateralmente com salina $(0,9 \%)$ e ipsilateralmente com pilocarpina $(2,4 \mathrm{mg} / \mu 1$ diluída em salina), ambos no volume de $1 \mu \mathrm{lem}$ um tempo de 1 minuto. Aproximadamente entre os tempo de 30 e 50 minutos os animais apresentaram crises autos sustentadas $S E$ que foram registradas segundo os estágios correspondentes aos da escala de Racine (RACINE, 1972).

\subsection{Análise comportamental}

Todos os animais submetidos ao $S E$ foram analisados quanto à latência para início e severidade das crises epilépticas. Foram, ainda, computados o número de animais que morreram durante ou após o $S E$ e os que tiveram remissão espontânea das crises antes de duas horas. As crises foram classificadas de acordo com a escala de Racine (RACINE, 1972).

\subsection{Avaliação histopatológica}

\subsubsection{Perfusão e fixação do tecido}

Após o acompanhamento comportamental, os animais foram profundamente anestesiados com tiopental sódico $(30 \mathrm{mg} / \mathrm{kg})$ administrado por via intraperitoneal. A perfusão intracardíaca foi realizada por intermédio de uma incisão no ventrículo esquerdo e, com o auxílio de uma agulha de gavagem, foi infundida uma solução de $100 \mathrm{ml}$ de $\mathrm{PBS}^{12}$ no

${ }^{12}$ PBS: tampão fosfato salina $=50 \mathrm{mM} \mathrm{Na}_{2} \mathrm{HPO}_{4}$ (Vetec) $\mathrm{pH} 7,4$ contendo $0,9 \%$ (p/v) $\mathrm{NaCl}$ (Quimex). Dissertação - Priscila A. Balista 
local. É importante ressaltar que o átrio direito foi seccionado previamente antes da infusão para permitir o escoamento dos líquidos. A seguir, uma solução de $250 \mathrm{ml}$ de paraformaldeído $^{13}$ tamponado $4 \%$ também foi infundida seguindo a mesma via de administração. Após esta perfusão o encéfalo foi removido da caixa óssea, com o auxílio de uma goiva, e colocado em solução de paraformaldeído também tamponado a 4\% um período de 4 horas. Seguindo este procedimento, os encéfalos foram desidratados. A desidratação teve por objetivo a extração de água das células e sua substituição por um solvente orgânico adequado para posterior inclusão em parafina.

O tecido encefálico foi colocado sucessivamente em uma série de soluções com concentrações crescentes de álcool, iniciando o processo com álcool a 70\% até álcool absoluto. Em seguida, o tecido foi diafanizado em xilol e incluído em parafina. Os blocos em parafina foram cortados de forma seriada em fatias de $8 \mu \mathrm{m}$ de espessura, em diferentes níveis da formação hipocampal padronizados como: região anterior (bregma-3.80 mm), média (bregma-4.30 mm) e posterior hipocampal (bregma-5.20 mm). As lâminas montadas em lâminas gelatinizadas permaneceram 24 horas em temperatura ambiente para secagem, sendo escorridas em estufa a $60{ }^{\circ} \mathrm{C}$ por um período de 2 horas e armazenadas para posterior realização das imuno-histoquímicas de NeuN, GFAP e Akt. O procedimento relatado para a realização da imuno-histoquímica é o protocolo padrão adotado pelo Laboratório de Investigação em Epilepsia do Hospital das Clínicas da Faculdade de Medicina da Universidade de São Paulo localizada em Ribeirão Preto.

\footnotetext{
${ }^{13}$ Todos os solventes utilizados são da marca Synth
} 


\subsection{Imuno-histoquímica}

A primeira etapa da imuno-histoquímica é a desparafinização, a qual visa a passagem dos cortes histológicos de uma situação hidrofóbica para uma hidrofílica. As lâminas foram incubadas em estufa histológica a $60{ }^{\circ} \mathrm{C}$ por 30 minutos em jarro coplin. Essa temperatura corresponde ao ponto de fusão da maioria das parafinas comerciais.

Imediatamente após a retirada das lâminas da estufa, elas foram imersas num primeiro recipiente à temperatura ambiente contento xilol (xilol I) por 5 minutos. Em seguida, as lâminas foram colocadas numa segunda solução de xilol (xilol) II e depois em uma solução de xilol-álcool absoluto.

A etapa de hidratação das peças consistiu na utilização de soluções com concentrações decrescentes de álcoois, sendo elas de $95 \%, 90 \%, 80 \%, 70 \%$ e $50 \%(\mathrm{v} / \mathrm{v})$ por um período de 2 minutos em cada solução, seguida de vários banhos em água destilada. O passo seguinte foi o bloqueio da peroxidase endógena conseguida por intermédio da incubação das secções em 4,5\% (v/v) de peróxido de hidrogênio $\left(\mathrm{H}_{2} \mathrm{O}_{2}\right)$ em PBS por um período de 20 minutos e, em seguida, iniciou-se a recuperação antigênica, a qual permite a exposição de epitopos proteicos do tecido. Nesta recuperação, as secções de cortes foram incubadas, dependendo da proteína a ser analisada, em coplin plástico com tampão 50 mM Tris- $\mathrm{HCl}(\mathrm{pH} 9,6)$ ou $10 \mathrm{mM}$ citrato de sódio $(\mathrm{pH} 6,0)$ em forno de micro-ondas da marca Brastemp DES modelo BMU27ABHNA, sendo que para o anticorpo anti-NeuN ajustou-se uma exposição em potência nominal de 4 minutos, seguida de outra de 3 minutos, com intervalo de 1 minuto entre elas. Para os anticorpos anti-GFAP e anti-Akt, foram realizadas duas exposições em potência nominal de 6 minutos cada, com intervalo de 1 minuto entre as mesmas.

A próxima etapa consistiu no bloqueio dos grupamentos aldeídos livres, responsáveis por impedir a formação de compostos instáveis e irreversíveis através da ligação dos seus grupamentos a grupos aminos livres, o que poderia impedir a ligação dos anticorpos primários 
aos sítios específicos. Incubamos as secções em Tris-Glicina ${ }^{14}$ por 40 minutos à temperatura ambiente. Depois realizamos o bloqueio dos sítios protéicos inespecíficos incubando as lâminas em tampão de bloqueio [tampão $\mathrm{B}^{15}$ contendo $5 \%(\mathrm{p} / \mathrm{v})$ de leite em pó desnatado Molico e $10 \%$ (v/v) de soro de cabra (Vector)] por 4-5 horas em temperatura ambiente.

Em seguida, foi realizada a incubação com o anticorpo primário por aproximadamente 16 horas, sendo que nas lâminas controles este anticorpo foi omitido. Passando este período, as lâminas foram lavadas 4 vezes com tampão B para a retirada do excesso de anticorpo, demorando cerca de 5 minutos cada processo de lavagem.

A incubação com o anticorpo secundário (antimouse ${ }^{16}$ ou antirabbit ${ }^{17}$ ) deu-se por 1 hora, em temperatura ambiente. As secções passaram por outra lavagem com tampão B, para retirar o excesso de anticorpo secundário que não se ligou ao tecido, e com tampão PBS por 1 vez, durante 5 minutos.

Depois, foi realizada a incubação com kit Elite ABC (Vector), onde misturamos $10 \mu \mathrm{L}$ de reagente $\mathrm{A}$ (solução rica em avidina) com $10 \mu \mathrm{L}$ de reagente $\mathrm{B}$ (solução rica em biotina conjugada com peroxidase) para cada $500 \mu \mathrm{L}$ de PBS. As secções foram incubadas nessa solução por 1 hora em temperatura ambiente. Como o anticorpo secundário é biotinizado, a avidina do kit se liga a ele, e a biotina do kit se liga a esta avidina. A biotina do kit é acoplada com peroxidase, molécula que ficará exposta na revelação subsequente.

Para a revelação descongelamos, um eppendorf de $1 \mathrm{~mL}$ de diaminobenzidina (DAB, Sigma) $10 \mathrm{mg} / \mathrm{mL}$ e misturamos a um volume de $24 \mathrm{~mL}$ de tampão Tris- $\mathrm{HCl}(\mathrm{pH}$ 7,6) e $8 \mu \mathrm{L}$ de $\mathrm{H}_{2} \mathrm{O}_{2}$ a $30 \%$ (v/v). O peróxido de hidrogênio é catalisador da reação de polimerização do DAB pela peroxidase, o que resulta em um precipitado de cor marrom escuro. O progresso do escurecimento da reação foi acompanhado visualmente. Com o objetivo de evitar a saturação,

\footnotetext{
14 Tris-Glicina: 0,1 M Glicina (Fluka) pH 7,4 ajustado com 0,1 M Tris (Vetec) básico.

${ }^{15}$ Tampão B: Preparado a partir do tampão A (20 mM Na $2 \mathrm{HPO}_{4}, 450 \mathrm{mM} \mathrm{NaCL} \mathrm{pH} \mathrm{7,4)} \mathrm{por} \mathrm{adição} \mathrm{de} 0,3 \%$ (v/v) de Triton X-100 (Vetec).

${ }^{16}$ Biotinylated swine anti-mouse IgG (Dako E0354), diluído a 1:200 com tampão de bloqueio.

${ }^{17}$ Biotinylated swine anti-rabbit IgG (Dako E0353), diluído a 1:100 com tampão de bloqueio.
} 
o tempo foi de no máximo 10 minutos. Após a revelação, as lâminas foram desidratadas em soluções com concentrações crescentes de álcool e, posteriormente, xilol, sendo montadas com lamínula e Kristalon (Harleco). Esperou-se um período mínimo de 24 horas de secagem das lâminas para, então, proceder às análises microscópicas.

\section{Detalhamento dos anticorpos primários}

- Anti-NeuN (Chemicon, MAB377), diluído a 1:500 em tampão de bloqueio. Este anticorpo monoclonal purificado de núcleos de neurônios de camundongo reconhece uma proteína nuclear específica de neurônios denominada NeuN, também encontrada no pericário e prolongamentos proximais de neurônios de vertebrados. Fonte:http://www.chemicon.com/browse/productdetail.asp?ProductID=MAB377.

- Anti-GFAP (Dako, M0761), diluído a 1:500 em tampão de bloqueio. Este anticorpo monoclonal de camundongos reconhece astrócitos em condições normais e patológicas. Fonte:http://www.dakousa.com/index/prod_search/prod_products.html productareaid $=38 \&$ baseprodidver $=\mathrm{A} 104410003$.

- Anti-Akt (Cell Signaling,C67E7), diluído a 1:200 em tampão de bloqueio.Este anticorpo monoclonal de coelho detecta níveis endógenos da proteína total Akt, não apresentando reações cruzadas com outras proteínas. Fonte: http://www.cellsignal.com/products/4691.html. 


\subsection{Análise das lâminas}

A contagem neuronial foi realizada em secções submetidas à imuno-histoquímica de NeuN e a avaliação da reação astroglial foi realizada por quantificação da área marcada e densidade óptica integrada-IOD em secções submetidas à imuno-histoquímica para a GFAP. A avaliação da expressão de Akt foi realizada por quantificação da área marcada e densidade óptica integrada-IOD em secções submetidas à imuno-histoquímica de Akt. As regiões analisadas foram a camada granular superior e inferior do giro denteado, hilo, CA1, CA2 e CA3a nos diferentes níveis hipocampais e na região posterior, ipsilateral à injeção da Pilo. Fotos das áreas de interesse foram captadas por uma câmera monocromática de alta resolução (Hamamatsu, tipo $\mathrm{CCD}$, modelo $\mathrm{C} 2400,75 \mathrm{H}$ ) instalada em microscópio de luz marca Olympus e modelo BX60, convertidas em sinais digitais a um computador MacIntosh (Modelo G3) usando um software de análise de imagem (NIH image, 1.56) com um aumento de 20 vezes para todas as regiões. As regiões escolhidas para a captação das imagens foram padronizadas e todas as fotos foram obtidas em iluminação fixa.

A contagem foi realizada através do programa Image $\mathrm{J}$ versão 1.42q, em 4 quadrados de $(50 \times 50) \mu \mathrm{m}$ por região, onde os quadrados considerados nas fotos foram aqueles locais de maior acúmulo de células. Para o cálculo da densidade celular (células por $\mathrm{mm}^{3}$ ) utilizamos a seguinte fórmula:

$$
\mathrm{N}^{0} \text { de células } / \mathrm{mm}^{3}=\frac{(\text { contagem celular }) \mathrm{X}(\text { fator de Abercrombie })}{(\text { área total }) \mathrm{X}(\text { espessura do corte })}
$$

Onde:

contagem celular: corresponde ao número absoluto de células contadas em cada região.

fator de Abercrombie (1946): é obtido pela consideração do diâmetro da célula e a espessura do corte (6,7 para células granulares e 17,3 para células do hilo e piramidais).

área total: correspondente ao número de quadrados contados e a espessura do corte correspondente a 8 $\mu \mathrm{m}$. 
Durante a quantificação da área marcada para as lâminas submetidas às imunohistoquímicas de GFAP e Akt, foi dada uma atenção especial a calibração na luminosidade do sistema óptico para garantir a uniformidade do sinal das imagens digitais. Para esta finalidade, foi utilizada uma régua de escalas de cinza (Kodak photographic step tablet $n^{\circ} 2,21$ steps densidade variando de 0,05 a 3,05), e se manteve constante a luminosidade do sistema. Estas imagens digitais foram analisadas também por intermédio do programa Image J. As regiões escolhidas para a captação das imagens foram padronizadas e todas as fotos foram calibradas de acordo com o aumento, observando as seguintes regras: para 20 vezes de aumento e 2,08 pixels, a dimensão equivale a $1 \mu \mathrm{m}$. Foi estabelecido um limiar único para GFAP e um para Akt, sendo que este limiar define o mínimo grau de cinza considerado como positivo para a presença da proteína estudada. Assim, valores iguais ou superiores ao limiar foram considerados como positivos para a marcação e valores inferiores foram considerados negativos, deste modo, fornecendo a área imunopositiva de anticorpo em cada área amostral. Para a quantificação da área imunopositiva foram amostrados 4 quadrados de $(25 \times 25) \mu \mathrm{m}$ para cada região hipocampal, e levando em consideração o valor da média das amostras em cada região.

Inicialmente, foi realizado o ensaio imuno-histoquímico contra a Akt ativa (fosforilada), no entanto dificuldades metodológicas na padronização da diluição para o anticorpo e quantidade insuficiente de fosfo-Akt dificultaram as análises para a forma fosforilada, sendo realizada apenas a imuno-histoquímica para Akt total.

Para a análise da imunorreatividade de GFAP, o grupo Wort+Pilo não foi avaliado por apresentar problemas no processamento histológico, como por exemplo o esfacelamento do tecido após a desparafinização e/ou recuperação antigênica, mesmo após repetição dos procedimentos de imuno-histoquímica. Para a análise da imunorreatividade de Akt, foram excluídos os subcampos CA3 para os grupos LY+Pilo e Wort+Pilo e CA1 para o grupo 
LY+Pilo devido a problemas metodológicos no processamento histológicos semelhantes aos descritos para a imuno-histoquímica de GFAP.

\subsection{Análise estatística}

Os dados comportamentais e histológicos foram estatisticamente analisados por intermédio da análise de variância (ANOVA), teste de Bonferroni com post hoc para variáveis com distribuição paramétrica ou teste de Kruskal-Wallis e o teste post hoc de Dunn para dados com distribuição não-paramétrica. Para as comparações de variáveis histológicas entre os hipocampos direito e esquerdo no mesmo grupo de animais, foi utilizado o teste $t$ para as variáveis paramétricas ou teste de Mann Whitney para as variáveis não-paramétricas. Os dados foram apresentados como média \pm erro padrão. O programa estatístico utilizado foi o SigmaStat 3.1 e foram consideradas diferenças significativas apenas valores de p menores que 0,05 . 
5. RESULTADOS 


\section{RESULTADOS}

\subsection{Mortalidade e distribuição dos animais no protocolo experimental.}

Do número total de animais submetidos ao $S E(\mathrm{n}=72), 29,2 \%(\mathrm{n}=21)$ não entraram em $S E ; 13,9 \%(\mathrm{n}=10)$ apresentaram remissão espontânea do $S E$ e 15,3\% (n=11) morreram durante o $S E$. Desta forma, $41,7 \%(\mathrm{n}=30)$ foram incluídos no estudo.

Os animais foram divididos em grupos segundo os dados resumidos na Tabela 2.

Tabela 2: Número de animais inseridos em cada grupo de estudo

\begin{tabular}{lc}
\hline \multicolumn{1}{c}{ Grupos } & Número de animais \\
\hline LY+Pilo & 13 \\
Wort+Pilo & 6 \\
Sal+Pilo (1dias) & 6 \\
Sal+Pilo (7 dia) & 5 \\
Controle & 11 \\
Número total de animais & 30 \\
submetidos ao estudo de SE* & \\
\hline * Dos 72 ratos iniciais, apenas 30 puderam entrar no protocolo de estudo. &
\end{tabular}

\subsection{Avaliação comportamental}

\subsubsection{Comportamento após administração de Pilocarpina}

O período de latência para o início do $S E$ foi maior no grupo Wort+Pilo (42 minutos) do que no Sal+Pilo (24 minutos), ANOVA, pós-teste de Bonferroni $\mathrm{p}<0,04$. Não foram encontradas diferenças estatisticamente significantes entre os demais grupos. A severidade do SE não foi diferente entre os grupos LY+Pilo, Wort+Pilo e Sal+Pilo (Figura 2). 

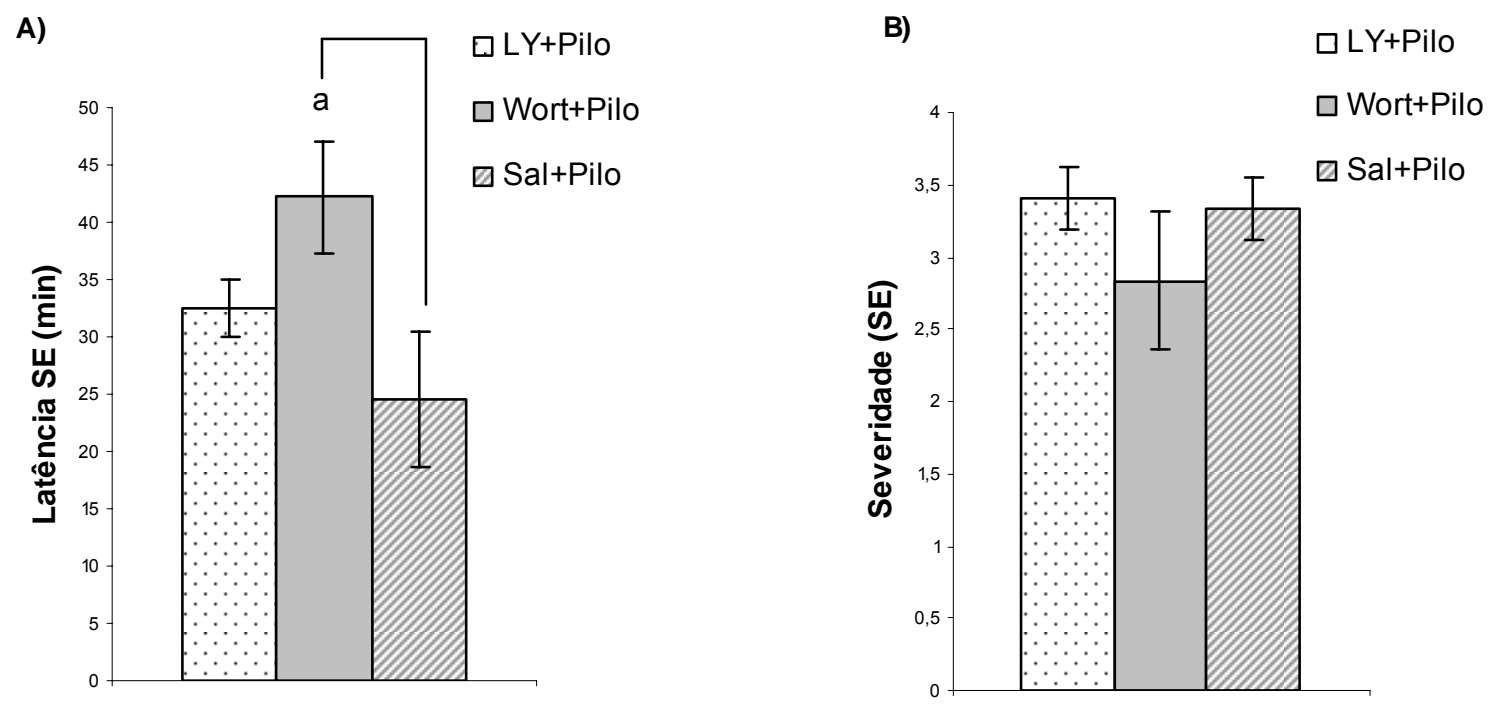

Figura 2: (A) Latência para início do $S E$ (minutos); a: ANOVA; pós-teste de Bonferroni p=0,04, (B) Severidade do $S E$ segundo a escala de Racine (RACINE, 1972) (teste de Kruskal-Wallis $\mathrm{p}=0,3$ ).

A manifestação motora do $S E$ não foi diferente para os grupos LY+Pilo; Wort+Pilo e Sal+Pilo. Os animais permaneceram a maior parte do tempo com crises correspondentes aos estágios 2-3-4 da escala de Racine (RACINE, 1972) alternadas com clonias, tremores da cabeça e corpo e comportamento agitado.

\subsection{Análise Histológica}

\subsubsection{Sítio de injeção versus lado contralateral}

\subsection{1.a Densidade Neuronial Média nos Grupos Controle}

A avaliação da densidade neuronial foi realizada nos grupos controles DMSO+Sal e Sal+Sal a fim de verificarmos se a injeção de DMSO teria alguma influência na densidade neuronial. Não encontramos diferença na densidade neuronial média em nenhuma das regiões hipocampais analisadas ao compararmos os grupos DMSO+Sal e Sal+Sal (Figura 3). Assim, consideramos ambos como um só grupo Controle. 


\section{A}

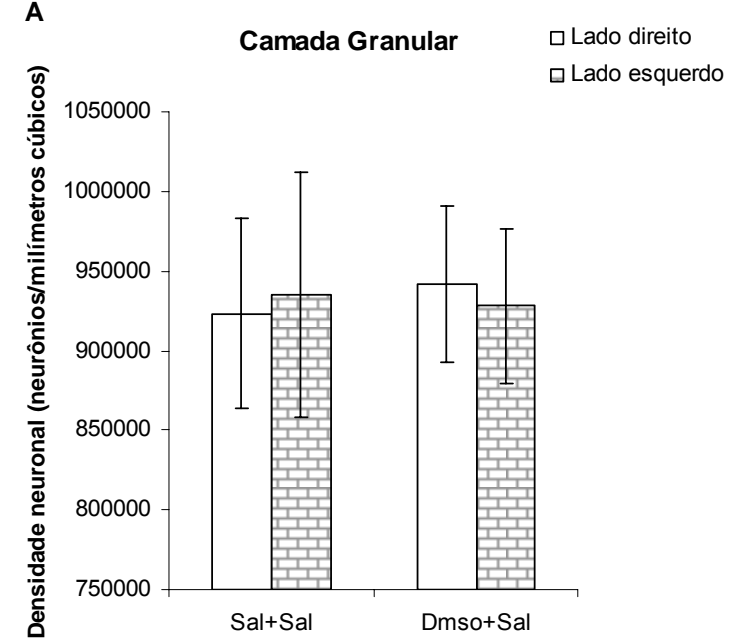

C
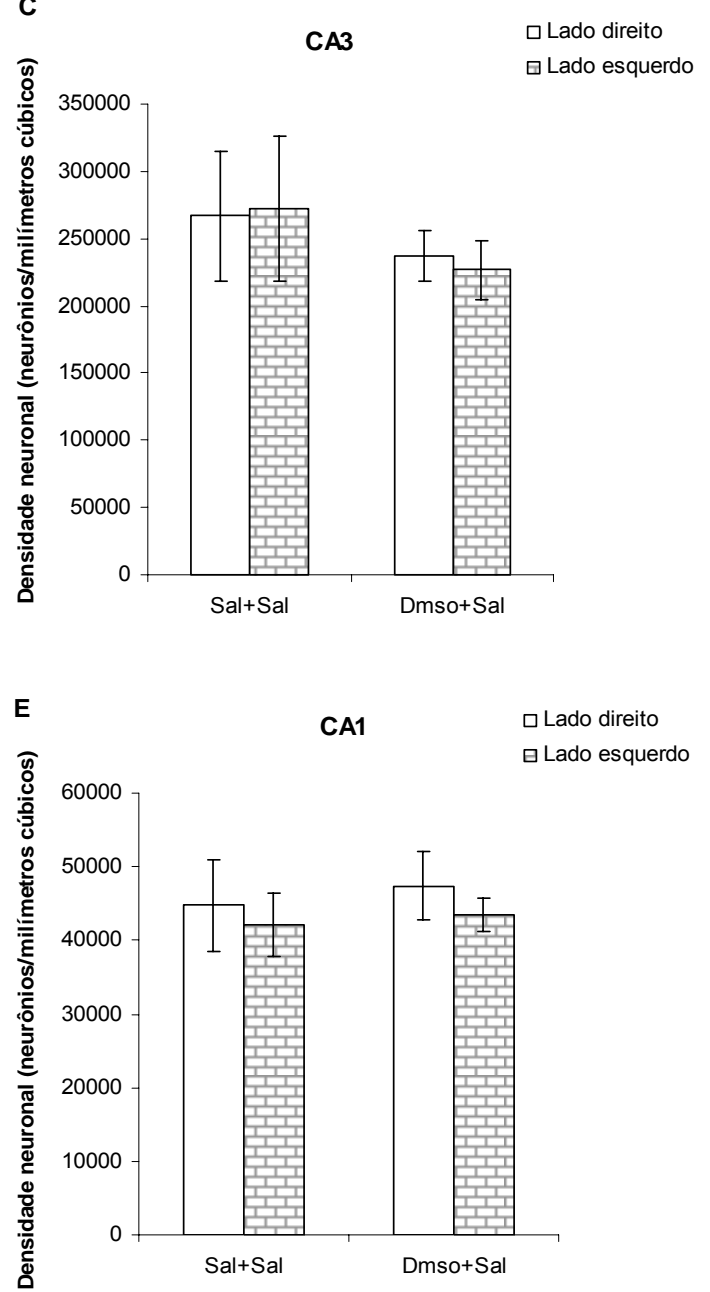

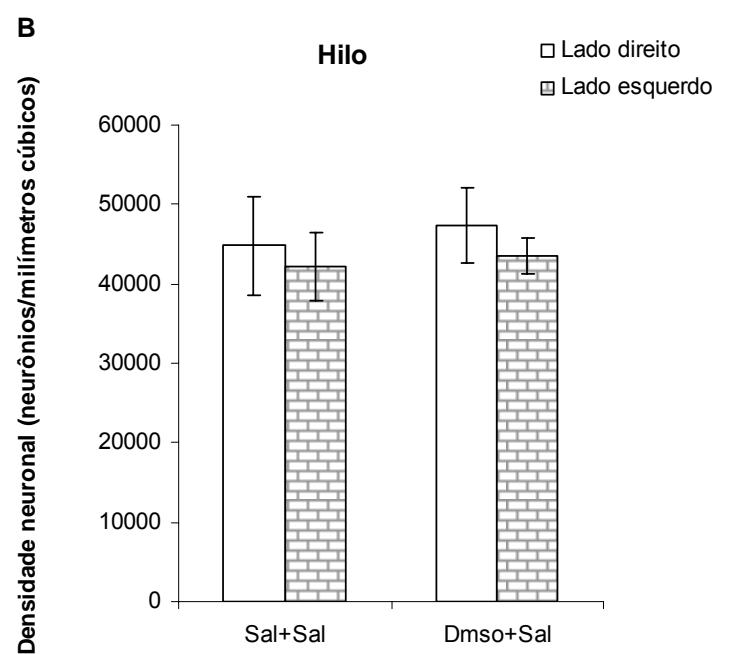

D

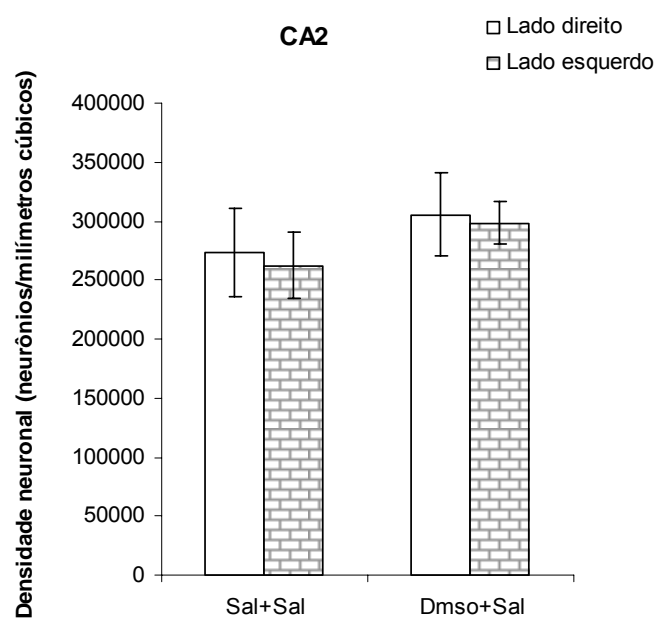

Figura 3: Densidade neuronial média no hipocampo (sítio da injeção versus lado contralateral) nos grupos DMSO+Sal e Sal+Sal. Não foram identificadas diferenças estatisticamente significantes entre os lados ipsilateral e contralateral para nenhum dos grupos estudados. A: densidades neuronial média na camada granular $(\mathrm{p}=0,895), \mathbf{B}$ : densidades neuronial média na região do hilo $(\mathrm{p}=0,694), \mathbf{C}$ : densidades neuronial média em CA3 $(p=0,956), \quad \mathbf{D}$ : densidades neuronial média em CA2 $(p=0,870)$ e $\mathbf{E}$ : densidades neuronial média em $\mathrm{CA} 1(\mathrm{p}=0,923)$; (teste $\mathrm{t})$. 


\subsection{1.b Densidade Neuronial Média nos Grupos Tratados (LY+Pilo, Wort+Pilo e Sal+Pilo) e Controle.}

A densidade neuronial média no grupo de animas LY+Pilo, Wort+Pilo e Sal+Pilo evidenciou perda neuronal para o grupo LY+Pilo na região do hilo e CA3, conforme pode ser observado na Tabela 3 e na Figura 4.

Tabela 3: Densidade neuronial média no hipocampo (sítio de injeção versus lado contralateral) avaliada nas lâminas coradas para NeuN.

\begin{tabular}{|c|c|c|c|c|c|}
\hline $\begin{array}{l}\text { Região do } \\
\text { Hipocampo }\end{array}$ & $\begin{array}{c}\text { Grupo } \\
\text { Experimental }\end{array}$ & $\begin{array}{l}\text { Densidade média } \\
\text { (neurônios/mm³) }\end{array}$ & $\begin{array}{l}\text { Grupo } \\
\text { Controle }\end{array}$ & $\begin{array}{l}\text { Densidade média } \\
\text { (neurônios/mm³ } \text { ) }\end{array}$ & $\begin{array}{l}\text { Teste* } \\
\text { Estatístico }\end{array}$ \\
\hline hilo & LY+Pilo & 16.689 & $\mathrm{DMSO}+\mathrm{Sal}$ & 26.877 & $\mathrm{p}=0,014$ \\
\hline CA3 & LY+Pilo & 152.833 & $\mathrm{DMSO}+\mathrm{Sal}$ & 191.982 & $\mathrm{p}=0,025$ \\
\hline
\end{tabular}

*As análises estatísticas foram realizadas comparando a densidade média de neurônios do "Grupo Experimental (LY+Pilo)" com a do "Grupo de Controle" utilizando o teste t.

A

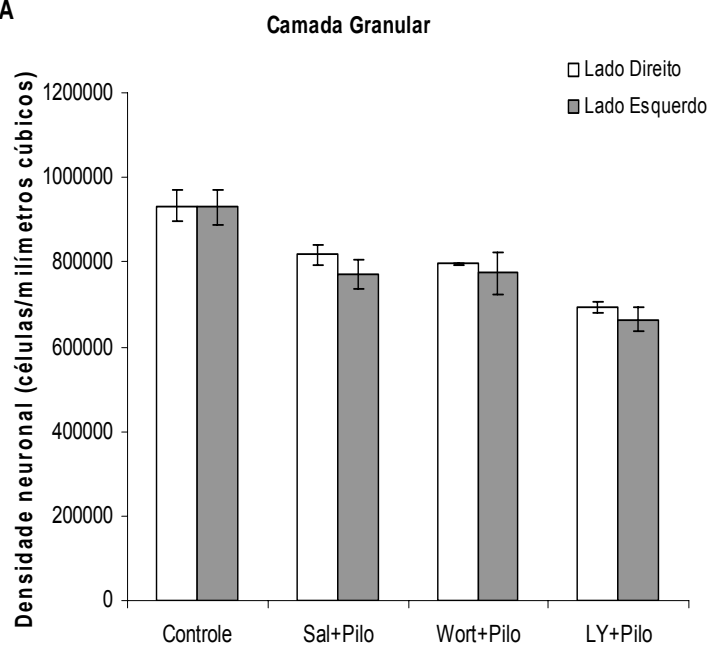

B

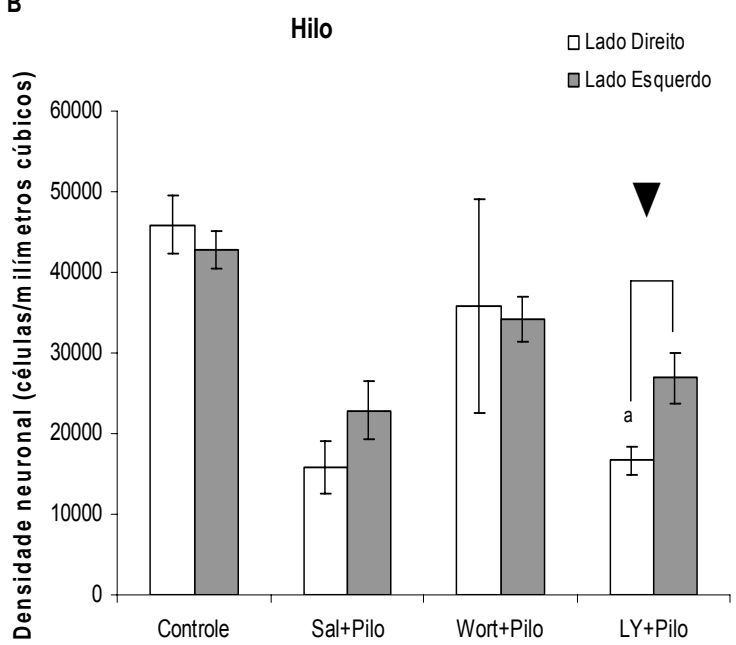


C

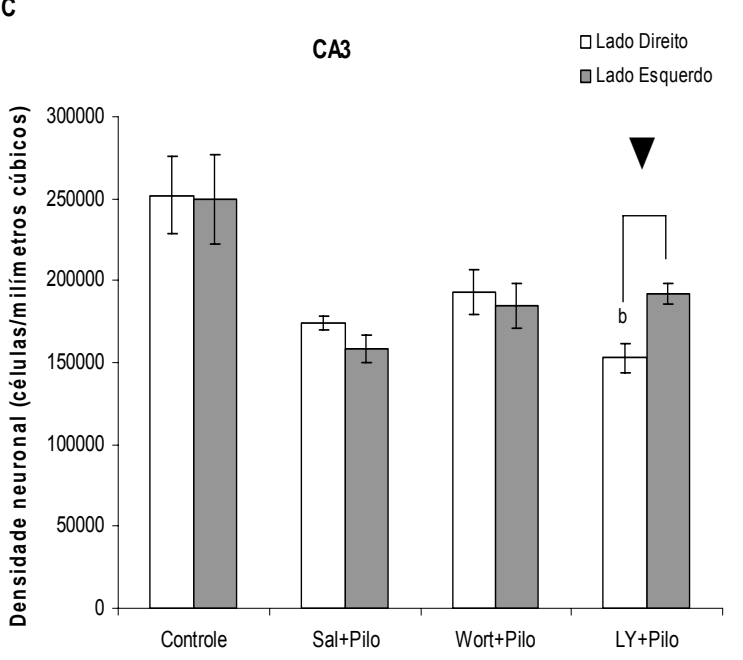

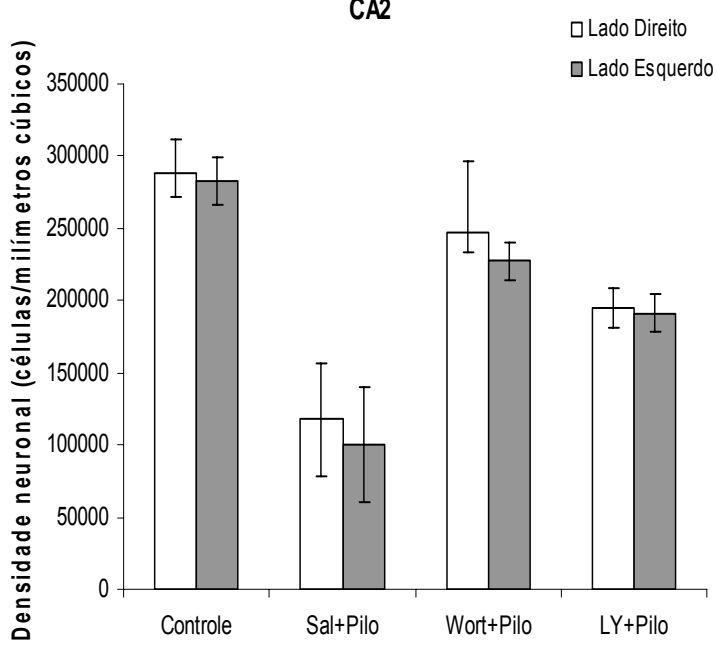

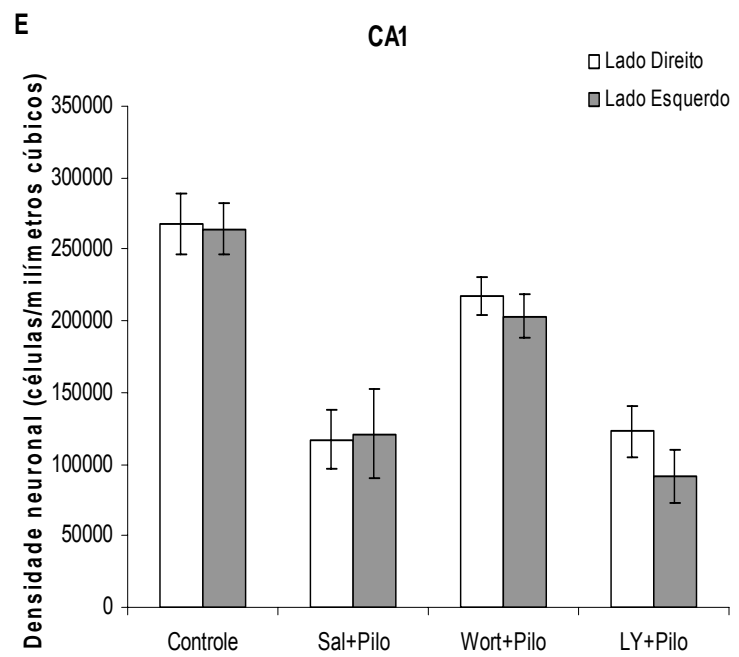

Figura 4: Densidade neuronial média no hipocampo (sítio da injeção versus lado contralateral) nos grupos LY+Pilo, Wort+Pilo, Sal+Pilo e Controle. A: densidade neuronial média na camada granular (Controle: $\mathrm{p}=0,90$, Sal+Pilo:p=0,36, Wort+Pilo:p=0,93, LY+Pilo:p=0,30), B: densidade neuronial média na região do hilo; a: $p=0,014, \mathbf{C}$ : densidade neuronial média no subcampo CA3 do hipocampo; $\mathbf{b}: p=0,025$, D: densidade neuronial média no subcampo CA2 do hipocampo (Controle: $p=0,87$, Sal+Pilo: $p=0,79$, Wort+Pilo: $p=0,375$, LY+Pilo:p=0,657) e E: densidade neuronial média no subcampo CA1 do hipocampo (Controle:p=0,92, Sal+Pilo:p=0,93, Wort+Pilo:p=0,58, $\mathrm{p}=0,32)$; (teste $\mathrm{t}$ ).

\subsection{1.c Análise da imunorreatividade para GFAP}

Não encontramos diferença estatisticamente significante entre os lados ipsilateral e contralateral ao analisarmos a área marcada por GFAP (Figura 5). 
A

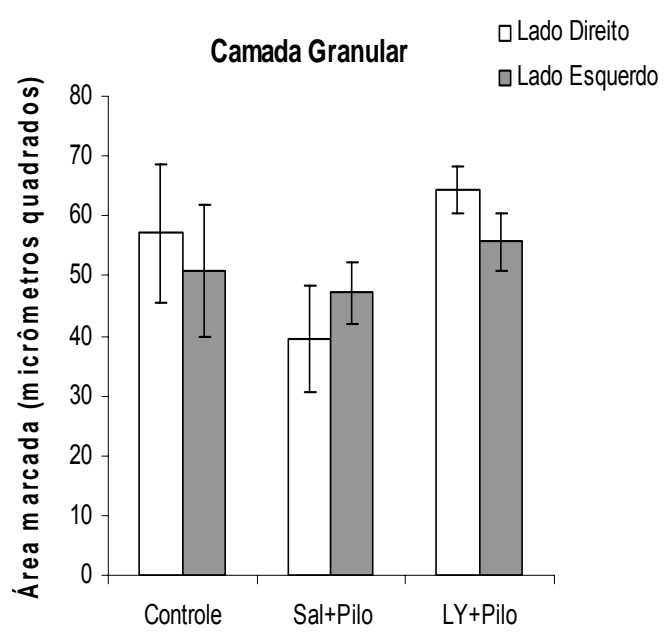

C

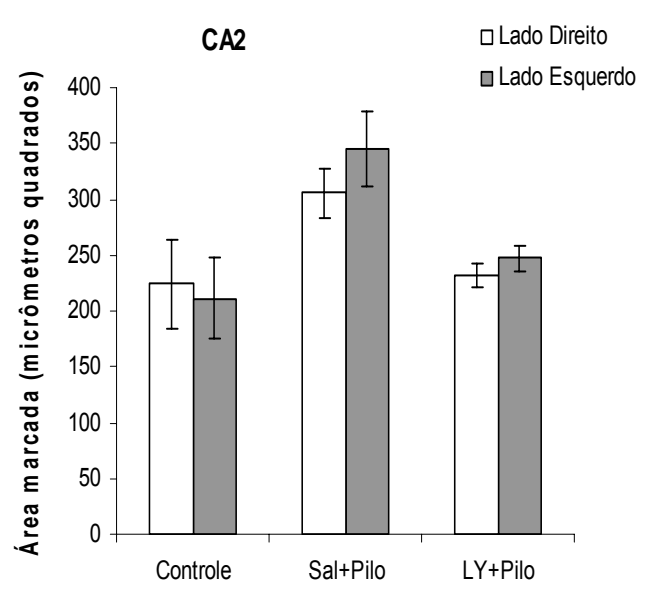

B

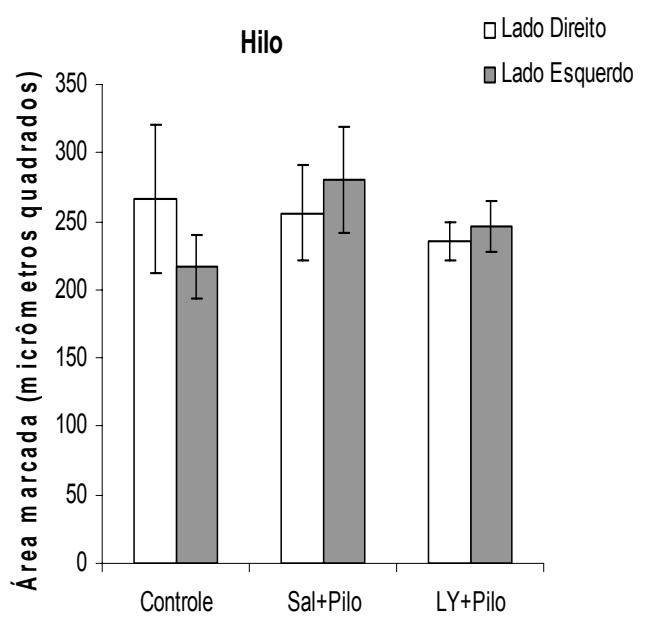

D

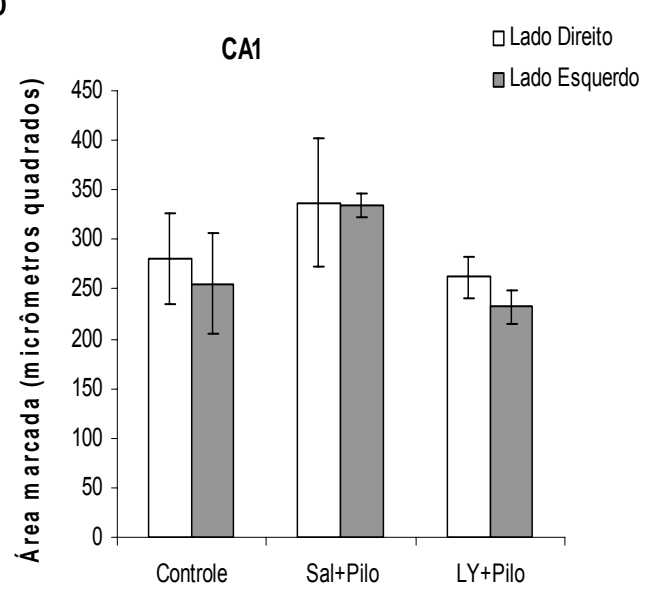

Figura 5: Análise da imunorreatividade para GFAP avaliada no hipocampo (sítio da injeção versus lado contralateral) nos grupos LY+Pilo, Sal+Pilo e Controle. Não foram identificadas diferenças estatisticamente significantes entre o lado ipsilateral e contralateral para nenhum dos grupos estudados. A: imunorreatividade para GFAP na camada granular (Controle: $p=0,73$, Sal+Pilo: $p=0,55$, LY+Pilo: $p=0,21$ ), B: imunorreatividade para GFAP na região do hilo (Controle: $p=0,48$, Sal+Pilo: $p=0,69$, LY+Pilo: $p=0,67$ ), C: imunorreatividade para GFAP no subcampo CA2 do hipocampo (Controle: $p=0,84$, Sal+Pilo: $p=0,97$, LY+Pilo: $p=0,63$ ), D: imunorreatividade para GFAP no subcampo CA1 do hipocampo (Controle: $p=0,77$, Sal+Pilo: $p=0,99$, LY+Pilo:p=0,40); (teste t).

\subsection{1.d Análise da imunorreatividade para Akt}

Não foi encontrada diferença estatisticamente significante entre os lados ipsilateral e contralateral ao analisarmos a imunorreatividade para Akt (Figura 6). 
A

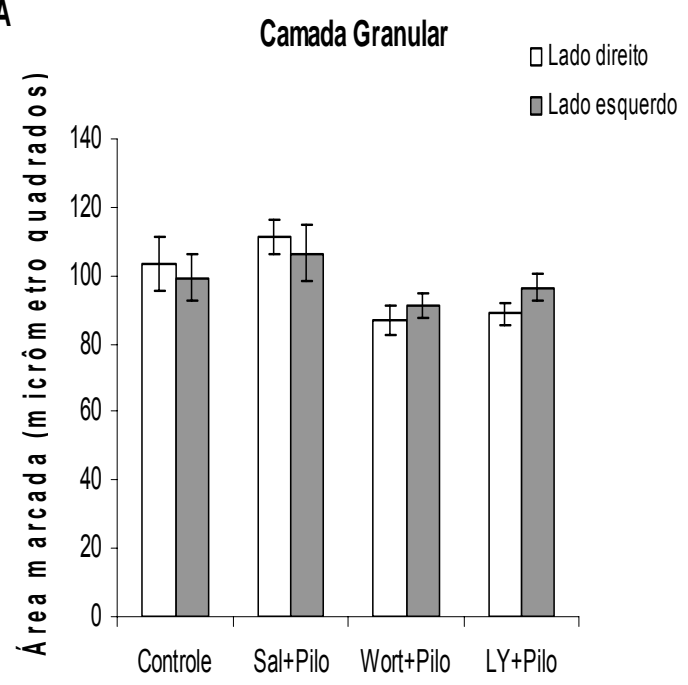

C

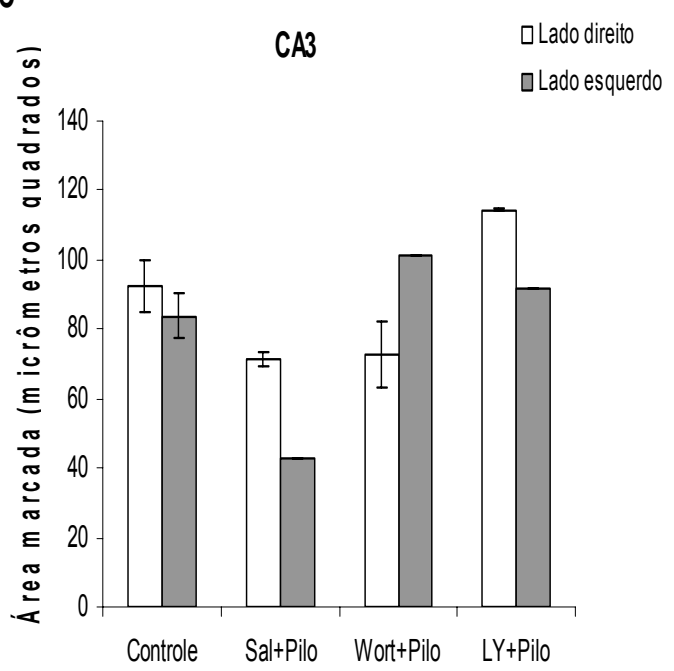

$\mathrm{E}$

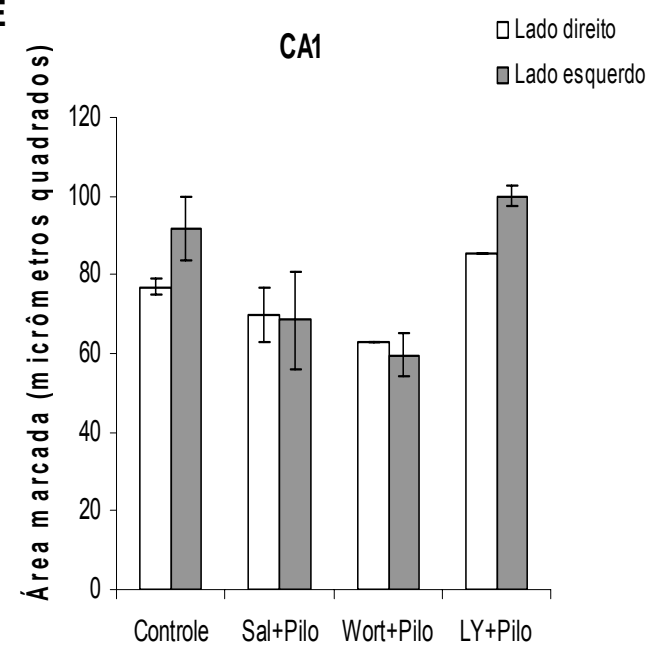

B

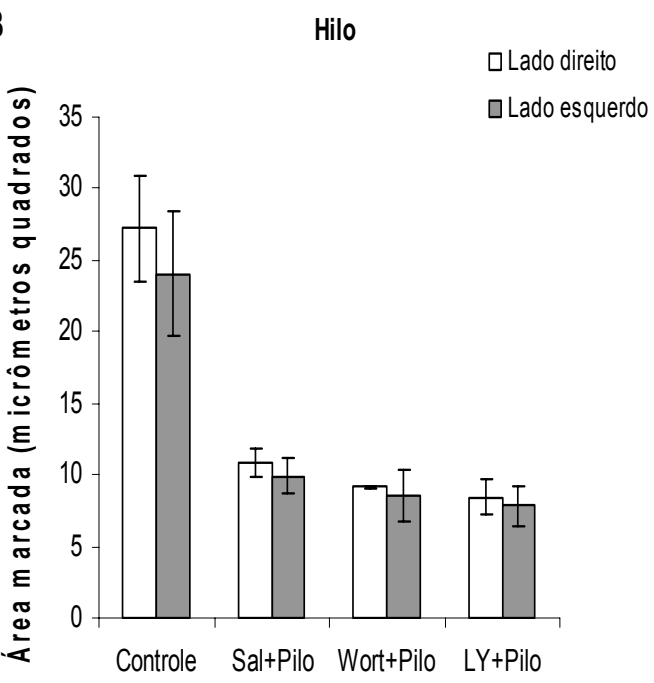

。

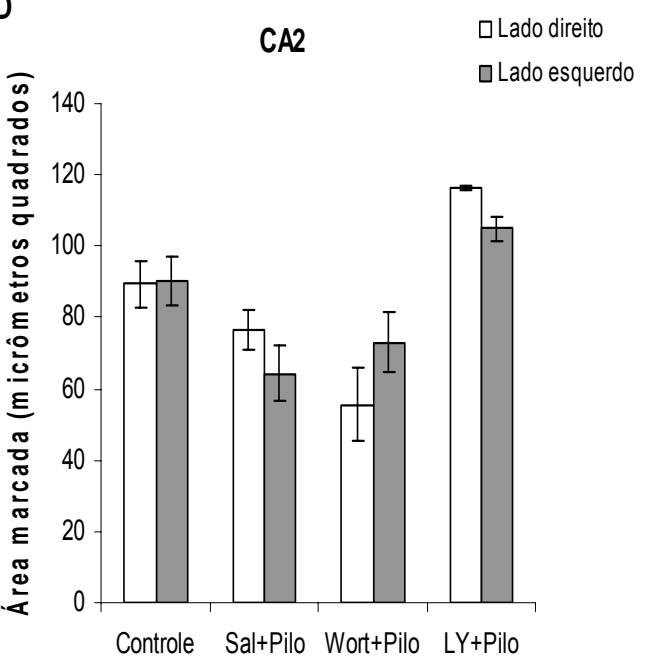

Figura 6: Análise da imunorreatividade para Akt avaliada no hipocampo (sítio da injeção versus lado contralateral) nos grupos LY+Pilo, Wort+Pilo, Sal+Pilo e Controle. Não foram identificadas diferenças estatisticamente significantes entre o lado ipsilateral e contralateral para nenhum dos grupos estudados. A: imunorreatividade para Akt na camada granular $\quad$ (Controle: $\mathrm{p}=0,77, \quad$ Sal+Pilo: $\mathrm{p}=0,72$, Wort+Pilo:p $=0,51, \quad$ LY+Pilo: $\quad \mathrm{p}=0,33), \quad \mathbf{B}$ : imunorreatividade para Akt na região do hilo (Controle: $\mathrm{p}=0,65$, Sal+Pilo: $\mathrm{p}=0,4$, Wort+Pilo: $\mathrm{p}=0,87$, LY+Pilo:p=0,82), C: imunorreatividade para Akt no subcampo CA3 do hipocampo (Controle: $\mathrm{p}=0,59$ ), $\mathbf{D}$ : imunorreatividade para Akt no subcampo CA2 do hipocampo (Controle: $\mathrm{p}=0,95, \quad$ Sal+Pilo: $\quad \mathrm{p}=0,42$, Wort+Pilo:p=0,27, $\quad$ LY+Pilo:p=0,33), $\quad$ E: imunorreatividade para Akt no subcampo CA1 do hipocampo (Controle: $\mathrm{p}=0,36$, Sal+Pilo: $\mathrm{p}=0,40)$; (teste $\mathrm{t}$ ). 


\subsubsection{Densidade Neuronial Média no hipocampo (análise ipsilateral à injeção de Pilo, valores médios entre as regiões anterior, média e posterior).}

A densidade neuronial média no grupo de animas LY+Pilo, Wort+Pilo e Sal+Pilo evidenciou perda neuronal nos diferentes grupos para a camada granular, região do hilo, CA3, CA2 e CA1, conforme pode ser observado na Tabela 4 e nas figuras 7A e 7B.

Tabela 4: Densidade neuronial média no hipocampo (análise do lado ipsilateral à injeção, valores médios entre as regiões anterior, média e posterior) avaliada nas lâminas coradas para NeuN.

\begin{tabular}{|c|c|c|c|c|c|}
\hline $\begin{array}{c}\text { Região do } \\
\text { Hipocampo }\end{array}$ & $\begin{array}{c}\text { Grupo } \\
\text { Experimental }\end{array}$ & $\begin{array}{l}\text { Densidade média } \\
\text { (neurônios/mm³ } \text { ) }\end{array}$ & $\begin{array}{c}\text { Grupo } \\
\text { Controle }\end{array}$ & $\begin{array}{l}\text { Densidade média } \\
\text { (neurônios/mm } / \mathbf{m m}^{3} \text { ) }\end{array}$ & $\begin{array}{c}\text { Teste * } \\
\text { Estatístico }\end{array}$ \\
\hline $\begin{array}{l}\text { Camada } \\
\text { Granular }\end{array}$ & LY+Pilo & 704.042 & Controle & 930.309 & $\mathrm{p}<0,001$ \\
\hline hilo & LY+Pilo & 18.136 & Controle & 46.728 & $\mathrm{p}<0,001$ \\
\hline CA3 & LY+Pilo & 160.531 & Controle & 256.917 & $\mathrm{p}<0,05^{* *}$ \\
\hline CA2 & LY+Pilo & 168.255 & Controle & 283.355 & $\mathrm{p}<0,001$ \\
\hline CA1 & LY+Pilo & 136.578 & Controle & 278.788 & $\mathrm{p}<0,001$ \\
\hline hilo & LY+Pilo & 18.136 & Wort+Pilo & 32.930 & $\mathrm{p}<0,001$ \\
\hline CA3 & LY+Pilo & 160.531 & Wort+Pilo & 214.745 & $\mathrm{p}<0,001$ \\
\hline CA2 & LY+Pilo & 168.254 & Wort+Pilo & 228.139 & $\mathrm{p}=0,035$ \\
\hline CA1 & LY+Pilo & 136.578 & Wort+Pilo & 203.262 & $\mathrm{p}=0,023$ \\
\hline $\begin{array}{l}\text { Camada } \\
\text { Granular }\end{array}$ & Wort+Pilo & 793.223 & Controle & 930.209 & $\mathrm{p}<0,001$ \\
\hline hilo & Wort+Pilo & 32.930 & Controle & 46.728 & $\mathrm{p}=0,007$ \\
\hline CA1 & Wort+Pilo & 203.362 & Controle & 278.878 & $\mathrm{p}=0,012$ \\
\hline hilo & Sal+Pilo & 17.846 & Controle & 46.728 & $\mathrm{p}<0,001$ \\
\hline
\end{tabular}


Tabela 4 (Continuação): Densidade neuronial média no hipocampo (análise do lado ipsilateral à injeção, valores médios entre as regiões anterior, média e posterior) avaliada nas lâminas coradas para NeuN

$\begin{array}{cccccc}\begin{array}{c}\text { Região do } \\ \text { Hipocampo }\end{array} & \begin{array}{c}\text { Grupo } \\ \text { Experimental }\end{array} & \begin{array}{c}\text { Densidade média } \\ \left(\text { neurônios } / \mathbf{m m}^{3}\right)\end{array} & \begin{array}{c}\text { Grupo } \\ \text { Controle }\end{array} & \begin{array}{c}\text { Densidade média } \\ \left(\text { neurônios } / \mathbf{m m}^{3}\right)\end{array} & \begin{array}{c}\text { Teste * } \\ \text { Estatístico }\end{array}\end{array}$

$\begin{array}{lllll}\text { CA1 Sal+Pilo } & 118.524 & \text { Wort+Pilo } & 203.262 & \mathrm{p}<0,017\end{array}$

\begin{tabular}{rlclcc} 
CA2 & Sal+Pilo & 156.068 & Controle & 283.356 & $\mathrm{p}<0,001$ \\
CA1 & Sal+Pilo & 118.524 & Controle & 278.788 & $\mathrm{p}<0,001$ \\
hilo & Sal+Pilo & 17.846 & Wort+Pilo & 32.930 & $\mathrm{p}=0,005$ \\
CA2 & Sal+Pilo & 156.068 & Wort+Pilo & 228.139 & $\mathrm{p}<0,04$ \\
CA1 & Sal+Pilo & 118.524 & Wort+Pilo & 203.262 & $\mathrm{p}<0,017$ \\
\hline
\end{tabular}

*As análises estatísticas foram realizadas comparando a densidade média de neurônios do "Grupo Experimental" com aquelas dos respectivos "Grupos Controle" pelo método ANOVA (pós-teste de Bonferroni). **Para o subcampo CA3 foi realizado o teste de Kruskal-Wallis (pós-teste de Dunn).

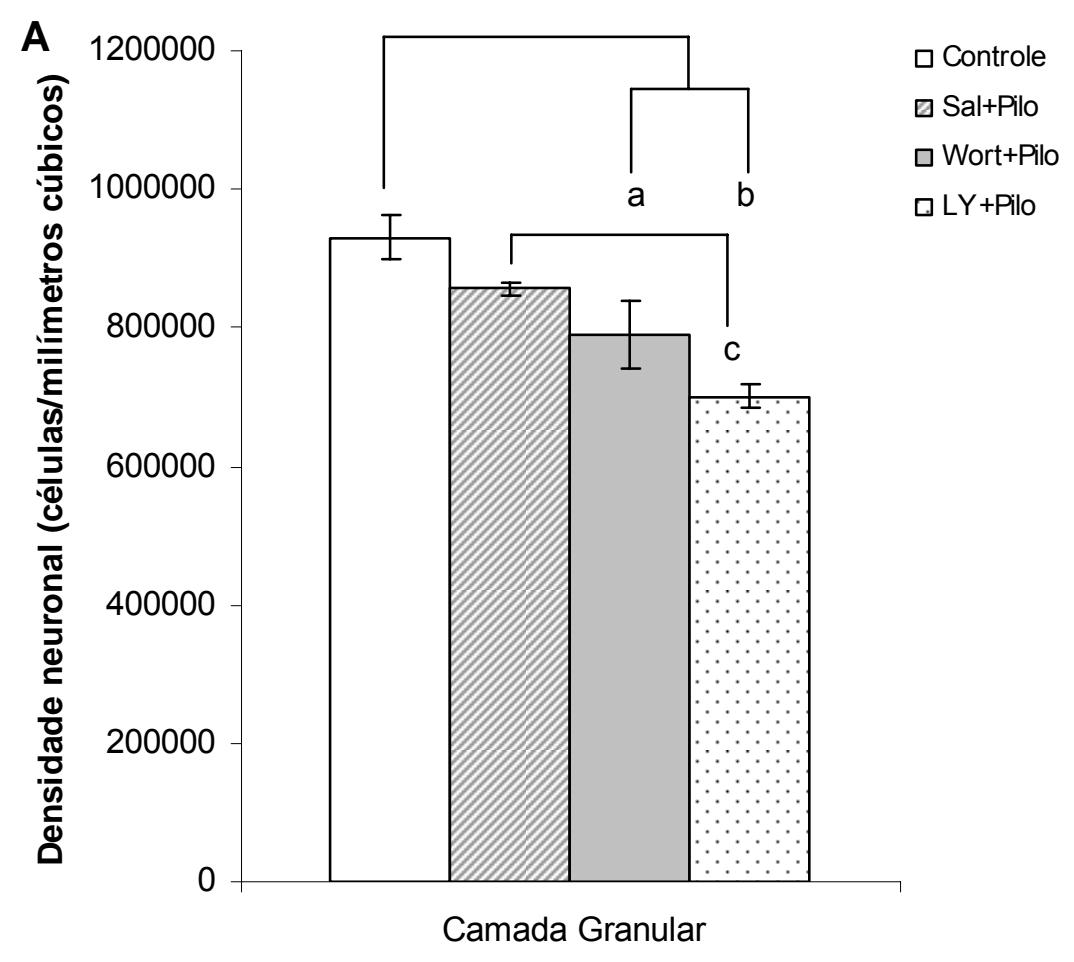




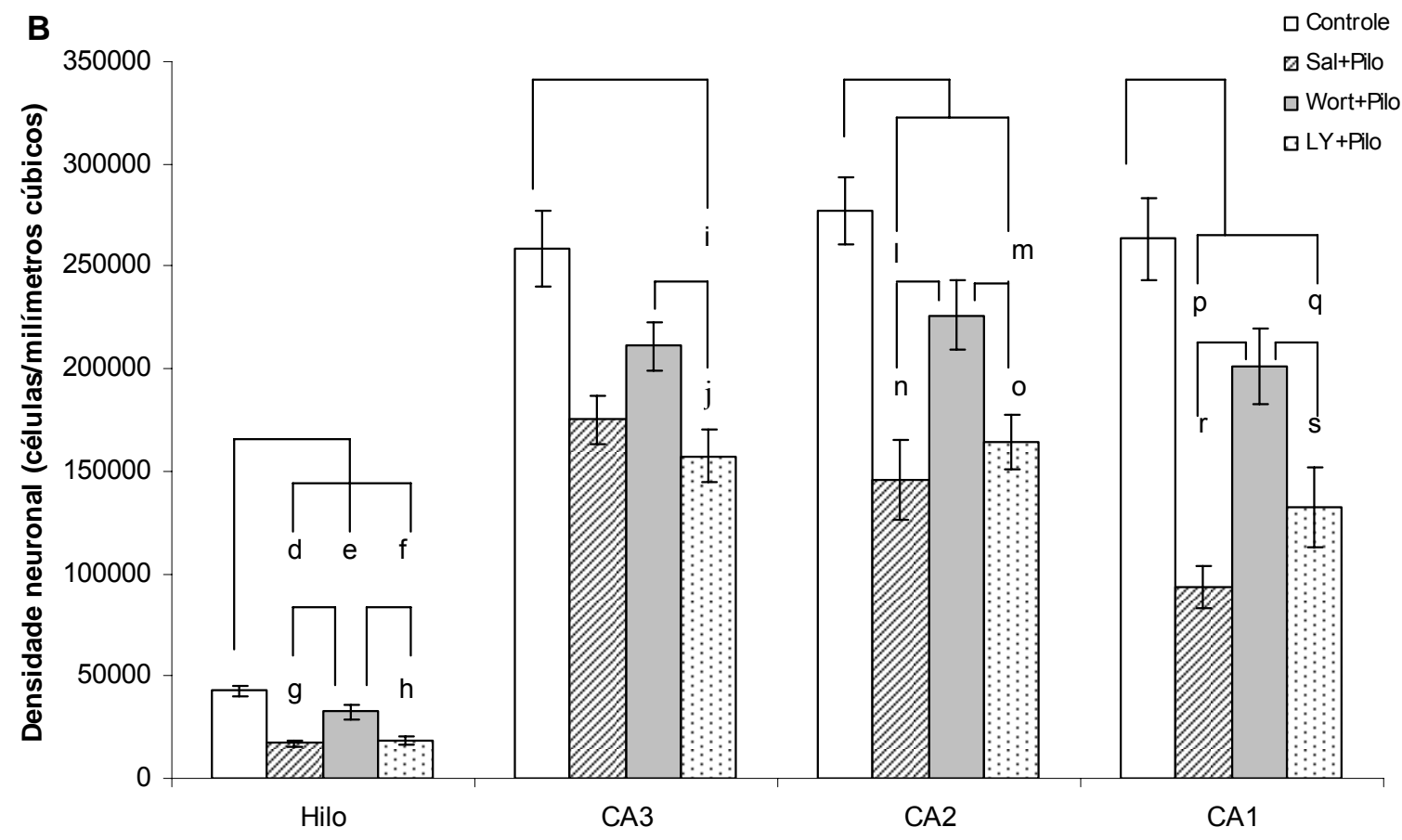

Figura 7: Densidade neuronial média avaliado no hipocampo (análise do lado ipsilateral à injeção, valores médios entre as regiões anterior, média e posterior), em cortes histológicos processados para a imunohistoquímica para NeuN nos grupos LY+Pilo, Wort+Pilo, Sal+Pilo e Controle. A: densidade neuronial média na camada granular; B: densidade neuronial média na região do hilo, subcampos CA3, CA2 e CA1 do

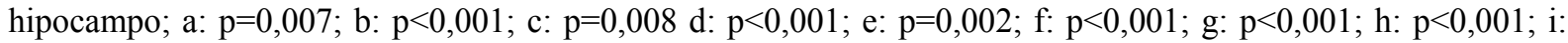
$\mathrm{p}<0,001 ; \mathrm{j}: \mathrm{p}<0,001 ; \mathrm{l}: \mathrm{p}<0,001 ; \mathrm{m}: \mathrm{p}<0,001 ; \mathrm{n}: \mathrm{p}=0,004 ; \mathrm{o}: \mathrm{p}=0,035 ; \mathrm{p}: \mathrm{p}<0,001 ; \mathrm{q}: \mathrm{p}<0,001 ; \mathrm{r}: \mathrm{p}=0,004 ; \mathrm{s}:$ $\mathrm{p}=0,035$ (teste de Kruskal-Wallis pós-teste de Dunn - subcampo CA3) (ANOVA, pós-teste de Bonferroni camada granular, hilo, CA2 e CA1). 

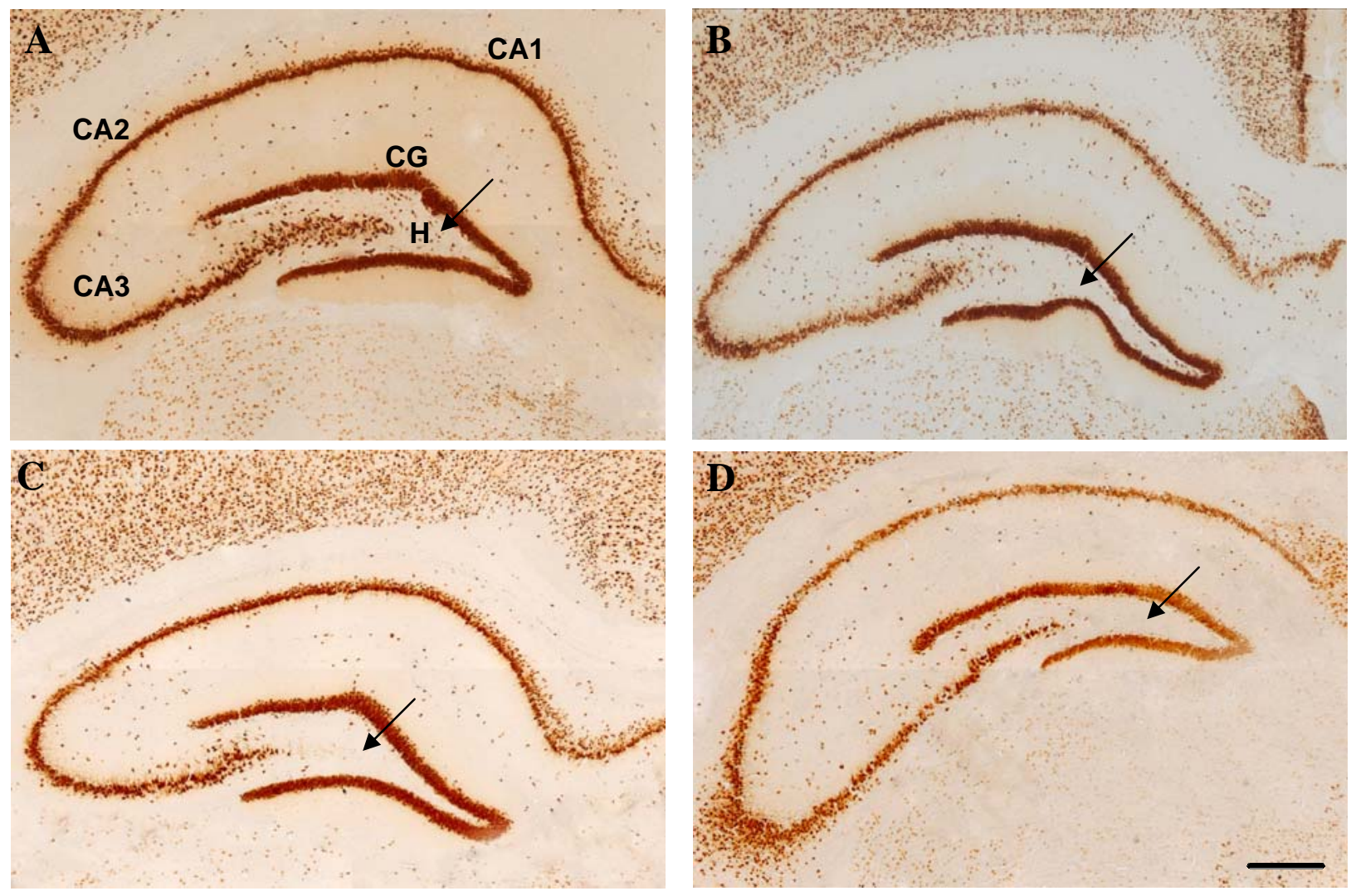

Figura 8: Fotomicrografias de secções coronais no hipocampo (análise do lado ipsilateral à injeção, valores médios entre as regiões anterior, média e posterior), imunomarcada para NeuN (lado ipsilateral à injeção da Pilo) nos grupos Controle (A), LY+Pilo (B), Wort+Pilo (C) e Sal+Pilo-sobrevida 7 dias pós-SE (D); CG: camada granular, H: região do hilo; Barra de calibração:200 $\mu \mathrm{m}$. Para o grupo Controle é observado um maior número de neurônios na região do hilo em comparação ao número reduzido de neurônios para os grupos LY+Pilo, Wort+Pilo e Sal+Pilo, indicado por setas. 


\subsubsection{Análise da imunorreatividade para GFAP}

A imunorreatividade para GFAP no grupo de animas LY+Pilo e Sal+Pilo evidenciou maior grau de marcação para o grupo LY+Pilo na camada granular, como pode ser observada na Tabela 5 e nas figuras 9A e 9B.

Não encontramos diferença estatisticamente significante na região do hilo, CA2 e CA1.

Devido a problemas metodológicos nos procedimentos histológicos, não foi possível incluir o grupo Wort+Pilo na análise quantitativa da imunorreatividade para a GFAP.

Tabela 5: Imunorreatividade para GFAP no hipocampo (análise do lado ipsilateral à injeção, valores médios entre as regiões anterior, média e posterior).

\begin{tabular}{cccccc}
\hline $\begin{array}{c}\text { Região do } \\
\text { Hipocampo }\end{array}$ & $\begin{array}{c}\text { Grupo } \\
\text { Experimental }\end{array}$ & $\begin{array}{c}\text { Área marcada } \\
\boldsymbol{\mu m}^{2}\end{array}$ & $\begin{array}{c}\text { Grupo } \\
\text { Controle }\end{array}$ & $\begin{array}{c}\text { Área marcada } \\
\boldsymbol{\mu m}^{\mathbf{2}}\end{array}$ & $\begin{array}{c}\text { Teste } \\
\text { Estatístico* }\end{array}$ \\
$\begin{array}{c}\text { Camada } \\
\text { Granular }\end{array}$ & LY+Pilo & 57 & Controle & 39 & $\mathrm{p}=0,037$ \\
$\begin{array}{c}\text { Camada } \\
\text { Granular }\end{array}$ & LY+Pilo & 57 & Sal+Pilo & 37 & $\mathrm{p}=0,037$ \\
\hline
\end{tabular}

*As análises estatísticas foram realizadas comparando a imunorreatividade para GFAP do "Grupo Experimental" com aquelas do "Grupo de Controle" pelo método ANOVA (pós-teste de Bonferroni). 

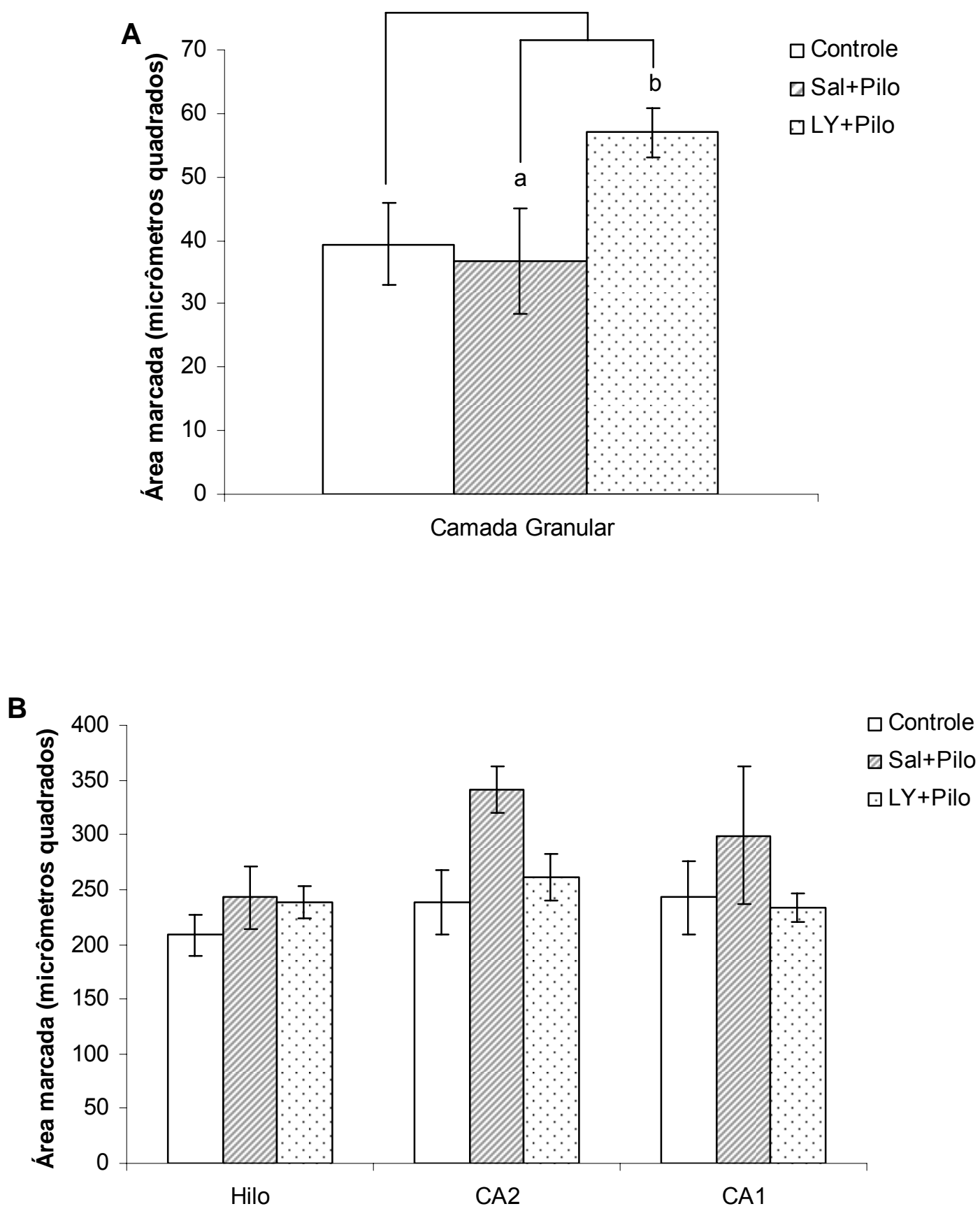

Figura 9: Análise da imunorreatividade para GFAP no hipocampo (análise do lado ipsilateral à injeção, valores médios entre as regiões anterior, média e posterior) nos grupos LY+Pilo, Sal+Pilo e Controle. A: imunorreatividade para GFAP na camada granular; B: imunorreatividade para GFAP na região do hilo, subcampos CA3, CA2 e CA1 do hipocampo; a e b: p=0,037 (ANOVA, pós-teste de Bonferroni). 

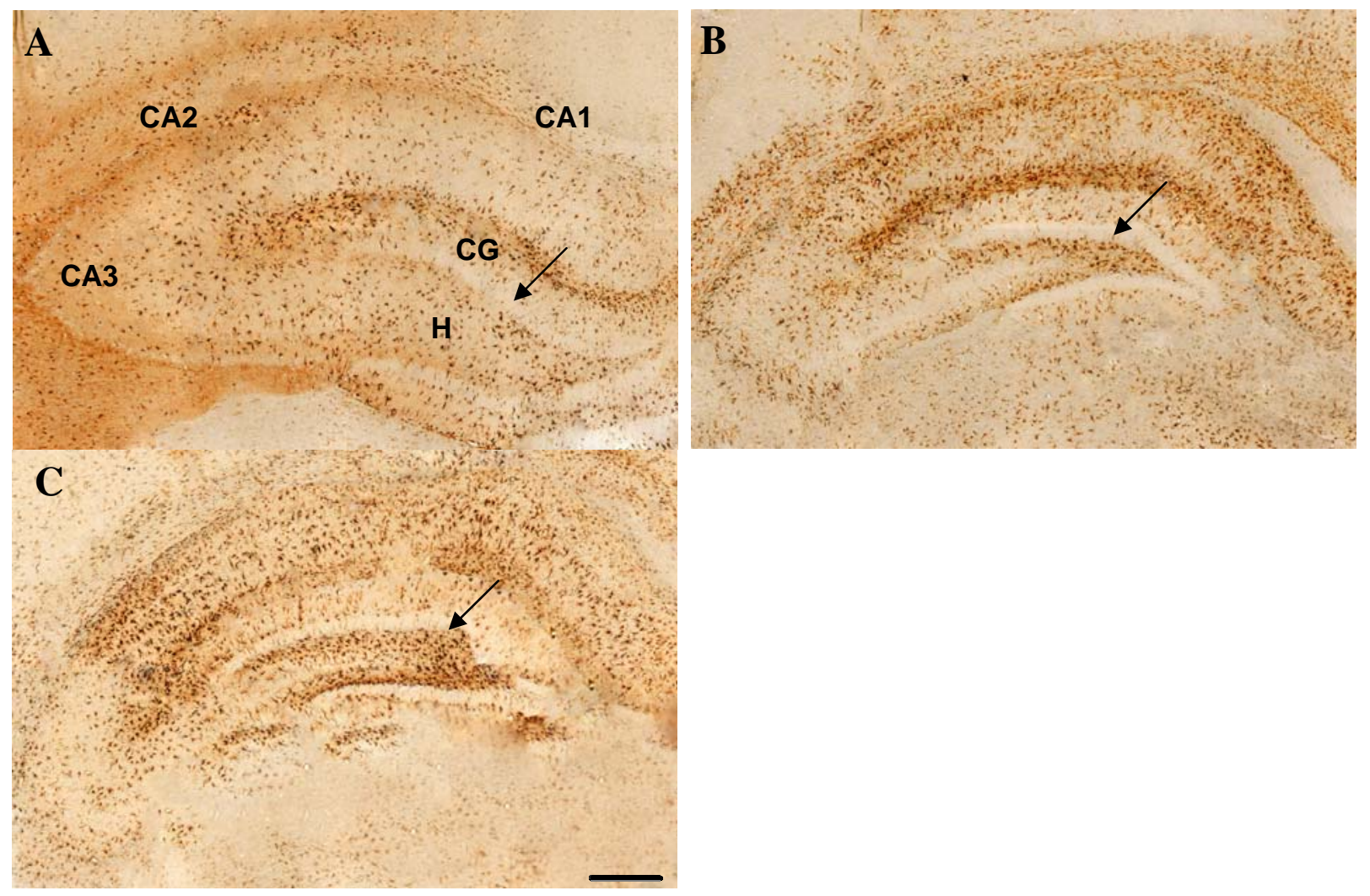

Figura 10: Fotomicrografias de secções coronais no hipocampo (análise do lado ipsilateral à injeção, valores médios entre as regiões anterior, média e posterior), imunomarcada para GFAP (lado ipsilateral à injeção da Pilo) nos grupos Controle (A), LY+Pilo (B) e Sal+Pilo-sobrevida 7 dias pós-SE (C); CG: camada granular, $\mathbf{H}$ :

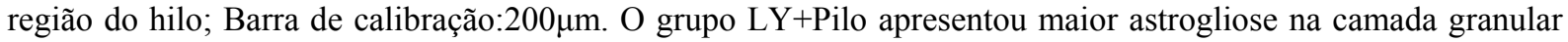
quando comparado aos grupos Controle e Sal+Pilo. 


\subsubsection{Análise da imunorreatividade para a Akt}

A imunorreatividade para Akt no grupo de animais tratados com LY+Pilo, Wort+Pilo, Sal+Pilo e Controle evidenciou menor grau de marcação para LY+Pilo e Wort+Pilo na região do hilo, conforme pode ser observado na Tabela 6 e figuras 11A e 11B.

Em CA2 foi identificada uma tendência estatística de (ANOVA $p=0,059$ ) entre os grupos LY+Pilo, Wort+Pilo, Sal+Pilo e Controle. Na camada granular, CA3 e CA1 não foram encontradas diferenças estatisticamente significantes.

Tabela 6: Imunorreatividade para Akt no hipocampo (análise do lado ipsilateral à injeção, valores médios entre as regiões anterior, média e posterior).

\begin{tabular}{cccccc}
\hline $\begin{array}{c}\text { Região do } \\
\text { Hipocampo }\end{array}$ & $\begin{array}{c}\text { Grupo } \\
\text { Experimental }\end{array}$ & $\begin{array}{c}\text { Área marcada } \\
\boldsymbol{\mu m}^{2}\end{array}$ & $\begin{array}{c}\text { Grupo } \\
\text { Controle }\end{array}$ & $\begin{array}{c}\text { Área marcada } \\
\boldsymbol{\mu m}^{2}\end{array}$ & $\begin{array}{c}\text { Teste* } \\
\text { Estatístico }\end{array}$ \\
\hline hilo & LY+Pilo & 8 & Controle & 22 & $\mathrm{p}=0,003$ \\
hilo & Wort+Pilo & 9 & Controle & 22 & $\mathrm{p}=0,003$ \\
\hline
\end{tabular}

*As análises estatísticas foram realizadas comparando a imunorreatividade para Akt do "Grupo Experimental" com àquelas do "Grupo Controle" pelo teste de Kruskal-Wallis (pós-teste de Dunn) 
A
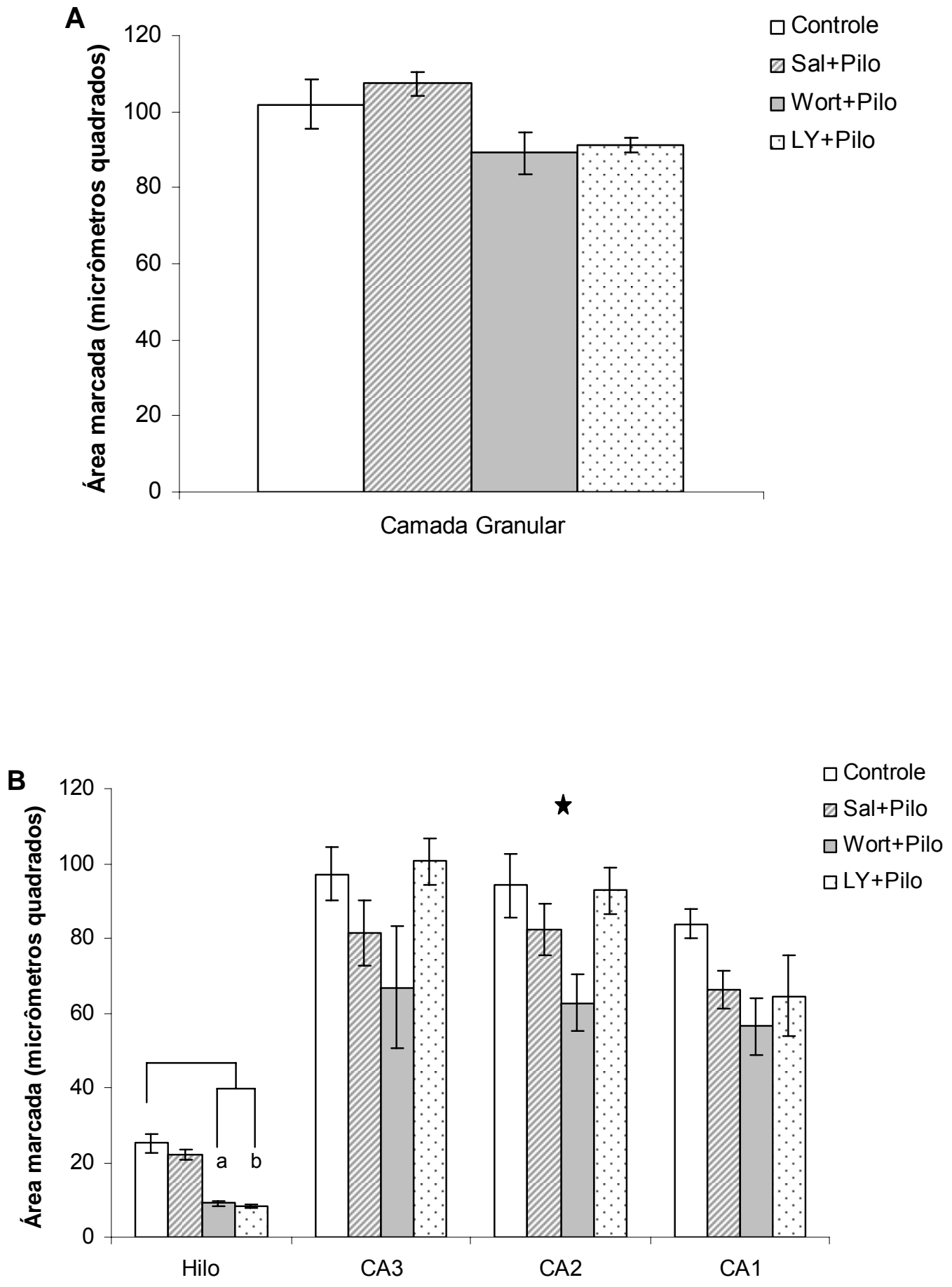

Figura 11: Análise da imunorreatividade para Akt avaliada no hipocampo (análise do lado ipsilateral à injeção, valores médios entre as regiões anterior, média e posterior) nos grupos LY+Pilo, Wort+Pilo, Sal+Pilo e Controle. A: imunorreatividade para Akt na camada granular; B: imunorreatividade para Akt na região do hilo, $\mathrm{CA} 3, \mathrm{CA} 2$ e CA1 do hipocampo; a e b: $\mathrm{p}=0,003 ; \star$ (CA2; $\mathrm{p}=0,059$, teste de Kruskal-Wallis). 

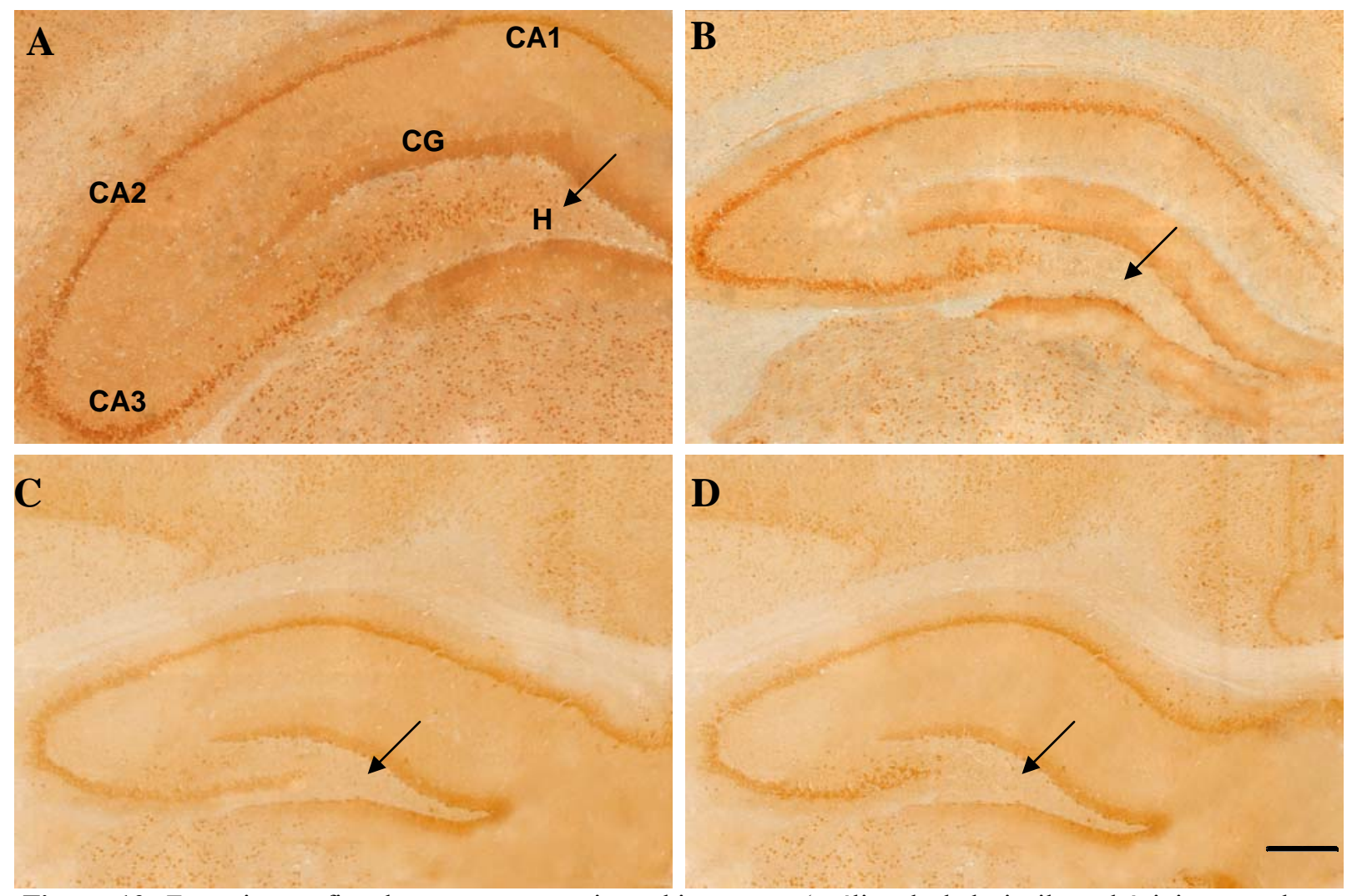

Figura 12: Fotomicrografias de secções coronais no hipocampo (análise do lado ipsilateral à injeção, valores médios entre as regiões anterior, média e posterior) expressando imunorreatividade para Akt (lado ipsilateral à injeção da Pilo) nos grupos Controle (A), LY+Pilo (B), Wort+Pilo (C) e Sal+Pilo-sobrevida de 7 dias pós-SE (D); CG: camada granular, H: região do hilo; Barra de calibração: $200 \mu \mathrm{m}$. Os grupos LY+Pilo e Wort+Pilo apresentaram menor expressão da Akt comparados ao Controle, indicado por seta. 


\subsubsection{Densidade Neuronial Média (ipsilateral à injeção de Pilo) na região posterior do hipocampo}

A densidade neuronial média no grupo de animais LY+Pilo, Wort+Pilo e Sal+Pilo evidenciou perda neuronal para os diferentes grupos na camada granular, região do hilo, CA3, CA2 e CA1 segundo a Tabela 7 e figuras $13 \mathrm{~A}$ e $13 \mathrm{~B}$.

Tabela 7: Densidade neuronial média na região posterior do hipocampo nas lâminas processadas para a imuno-histoquímica de NeuN.

\begin{tabular}{|c|c|c|c|c|c|}
\hline $\begin{array}{r}\text { Região do } \\
\text { Hipocampo }\end{array}$ & $\begin{array}{c}\text { Grupo } \\
\text { Experimental }\end{array}$ & $\begin{array}{l}\text { Densidade média } \\
\text { (neurônios/mm } / \mathbf{m m}^{3} \text { ) }\end{array}$ & $\begin{array}{c}\text { Grupo } \\
\text { Controle }\end{array}$ & $\begin{array}{c}\text { Densidade média } \\
\text { (neurônios/mm³) }\end{array}$ & $\begin{array}{c}\text { Teste* } \\
\text { Estatístico }\end{array}$ \\
\hline $\begin{array}{l}\text { Camada } \\
\text { Granular }\end{array}$ & LY+Pilo & 691.988 & Controle & 930.209 & $\mathrm{p}<0,001$ \\
\hline hilo & LY+Pilo & 16.689 & Controle & 50.066 & $\mathrm{p}<0,001$ \\
\hline CA3 & LY+Pilo & 152.833 & Controle & 244.181 & $\mathrm{p}=0,025$ \\
\hline CA2 & LY+Pilo & 194.993 & Controle & 295.125 & $\mathrm{p}=0,0016$ \\
\hline CA1 & LY+Pilo & 122.793 & Controle & 272.068 & $\mathrm{p}<0,001$ \\
\hline $\begin{array}{l}\text { Camada } \\
\text { Granular }\end{array}$ & Wort+Pilo & 795.465 & Controle & 930.209 & $\mathrm{p}=0,05$ \\
\hline hilo & Wort+Pilo & 35.837 & Controle & 50.066 & $\mathrm{p}=0,022$ \\
\hline hilo & Sal+Pilo & 15.810 & Controle & 50.066 & $\mathrm{p}<0,001$ \\
\hline CA2 & Sal+Pilo & 118.578 & Controle & 295.125 & $\mathrm{p}<0,001$ \\
\hline CA1 & Sal+Pilo & 122.793 & Controle & 272.068 & $\mathrm{p}<0,001$ \\
\hline hilo & Sal+Pilo & 15.810 & Wort+Pilo & 35.837 & $\mathrm{p}=0,005$ \\
\hline CA2 & Sal+Pilo & 118.577 & Wort+Pilo & 246.640 & $\mathrm{p}=0,026$ \\
\hline
\end{tabular}

\footnotetext{
*As análises estatísticas foram realizadas comparando a densidade média de neurônios do "Grupo Experimental" com àquelas dos respectivos "Grupos Controle" pelo método ANOVA (pós-teste de Bonferroni).
} 
A
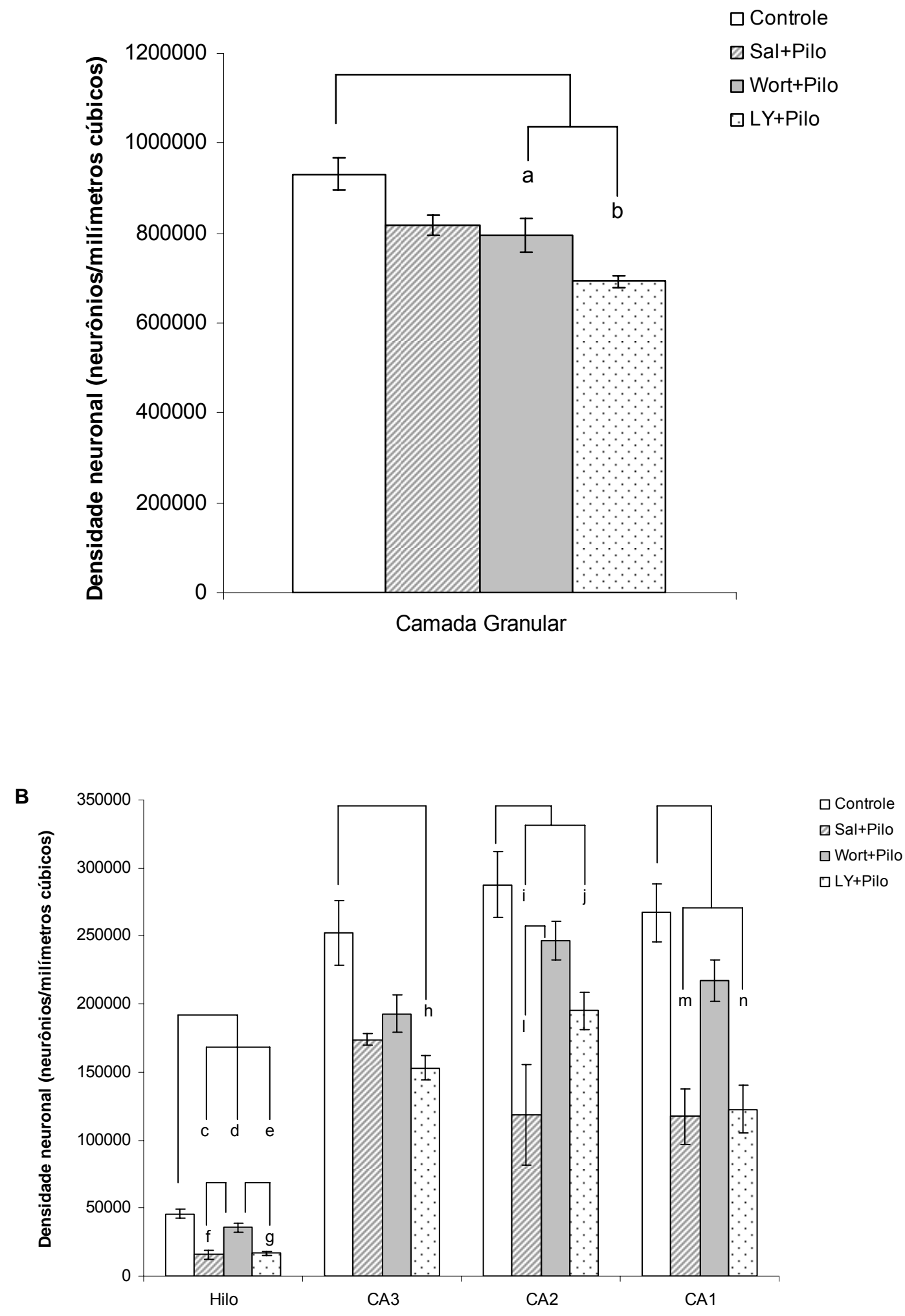

Figura 13: Densidade neuronial média na região posterior do hipocampo para NeuN nos grupos LY+Pilo, Wort+Pilo, Sal+Pilo e Controle. A: densidade neuronial média na camada granular; B: densidade neuronial média na região do hilo, CA3, CA2 e CA1 do hipocampo; a: $p=0,005 ; b$ : $p<0,001 ; c: p<0,001$; $p=0,022$; e: $p<0,001 ; f: p=0,005 ; g: p<0,001 ; h: p=0,025 ; i: p<0,001 ; j: p=0,016,1: p=0,026 ; m: p=0,001 ; n: p<0,001$. (ANOVA, pós-teste de Bonferroni). 


\subsubsection{Análise da imunorreatividade para GFAP}

Não foi encontrada diferença estatisticamente significante quando da análise da imonorreatividade para a GFAP nos grupos LY+Pilo, Sal+Pilo e Controle na camada granular, região do hilo, CA2 e CA1. Devido a problemas metodológicos nos procedimentos histológicos, não foi possível a avaliação quantitativa do subcampo CA3 (Figura 14).

Pelas mesmas razões, não foi possível incluir o grupo Wort+Pilo na análise quantitativa da imunorreatividade para a GFAP.
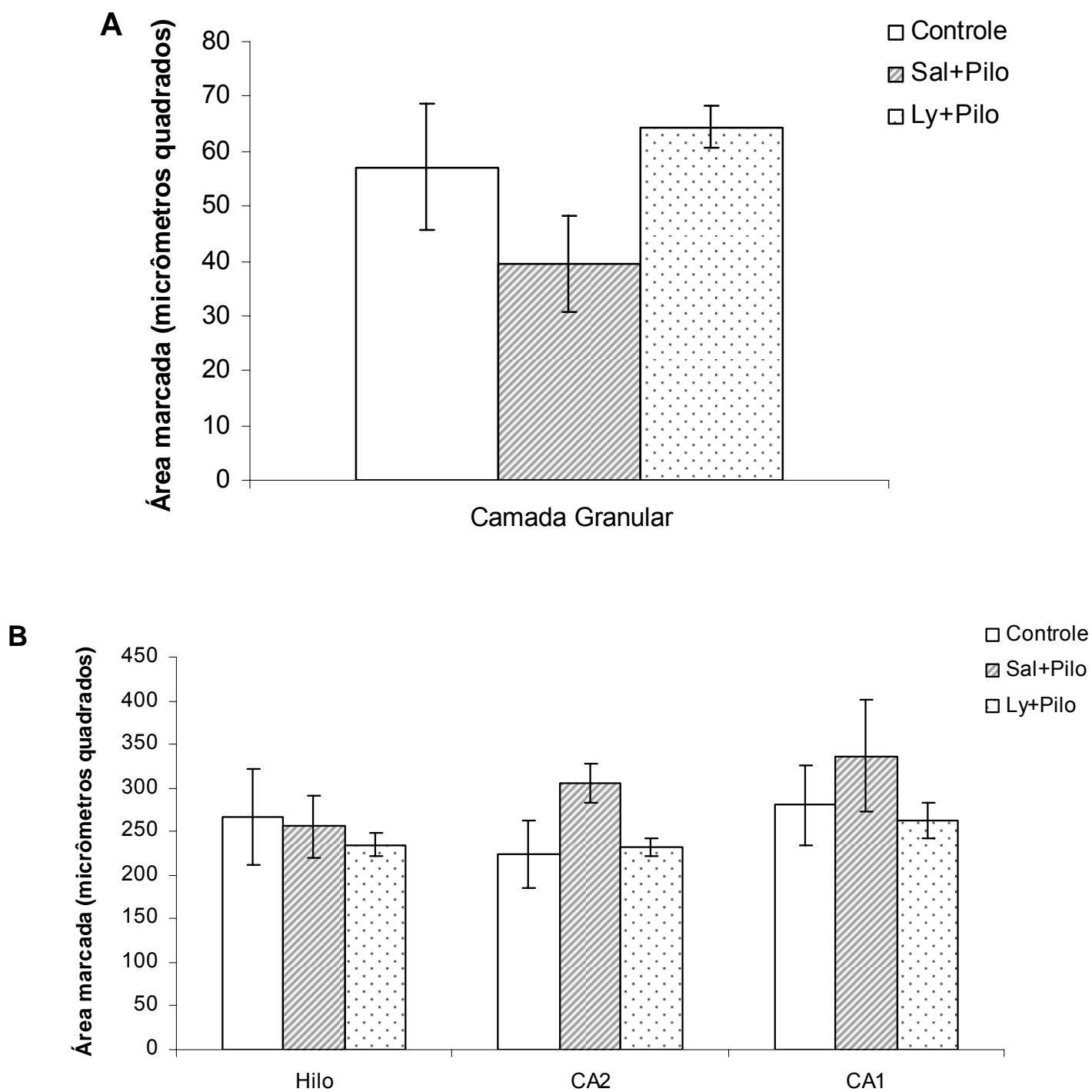

Figura 14: Análise da imunorreatividade para GFAP avaliada na região posterior do hipocampo nos grupos LY+Pilo, Sal+Pilo e Controle. Não foram identificadas diferenças estatisticamente significantes para os grupos estudados. A: imunorreatividade para GFAP na camada granular; B: imunorreatividade para GFAP na região do hilo, CA2 e CA1 do hipocampo. 


\subsubsection{Análise da imunorreatividade para a Akt}

A imunorreatividade para Akt no grupo de animais LY+Pilo, Wort+Pilo, Sal+Pilo e Controle evidenciou menor grau de marcação para LY+Pilo e Wort+Pilo na região do hilo, assim como o grupo Wort+Pilo apresentou menor grau de marcação em CA2, conforme pode ser observado na Tabela 8 e figuras 15A e 15B.

Para a camada granular, CA3 e CA1, não foram encontradas diferenças estatisticamente significantes.

Tabela 8: Análise da imunorreatividade para Akt na região posterior do hipocampo.

\begin{tabular}{cccccc}
\hline $\begin{array}{c}\text { Região do } \\
\text { Hipocampo }\end{array}$ & $\begin{array}{c}\text { Grupo } \\
\text { Experimental }\end{array}$ & $\begin{array}{c}\text { Área marcada } \\
\boldsymbol{\mu m}^{2}\end{array}$ & $\begin{array}{c}\text { Grupo } \\
\text { Controle }\end{array}$ & $\begin{array}{c}\text { Área marcada } \\
\boldsymbol{\mu m}^{2}\end{array}$ & $\begin{array}{c}\text { Teste* } \\
\text { Estatístico }\end{array}$ \\
hilo & LY+Pilo & 8 & Controle & 25 & $\mathrm{p}=0,022^{*}$ \\
hilo & Wort+Pilo & 9 & Controle & 25 & $\mathrm{p}=0,022^{*}$ \\
CA2 & Wort+Pilo & 55 & LY+Pilo & 116 & $\mathrm{p}=0,016^{* *}$
\end{tabular}

\footnotetext{
*As análises estatísticas foram realizadas comparando a imunorreatividade para Akt do "Grupo Experimental" com aquelas do "Grupo Controle" pelo teste de Kruskal-Wallis (pós-teste de Dunn); ** Análises realizadas pelo método ANOVA (pós-teste de Bonferroni).
} 
A

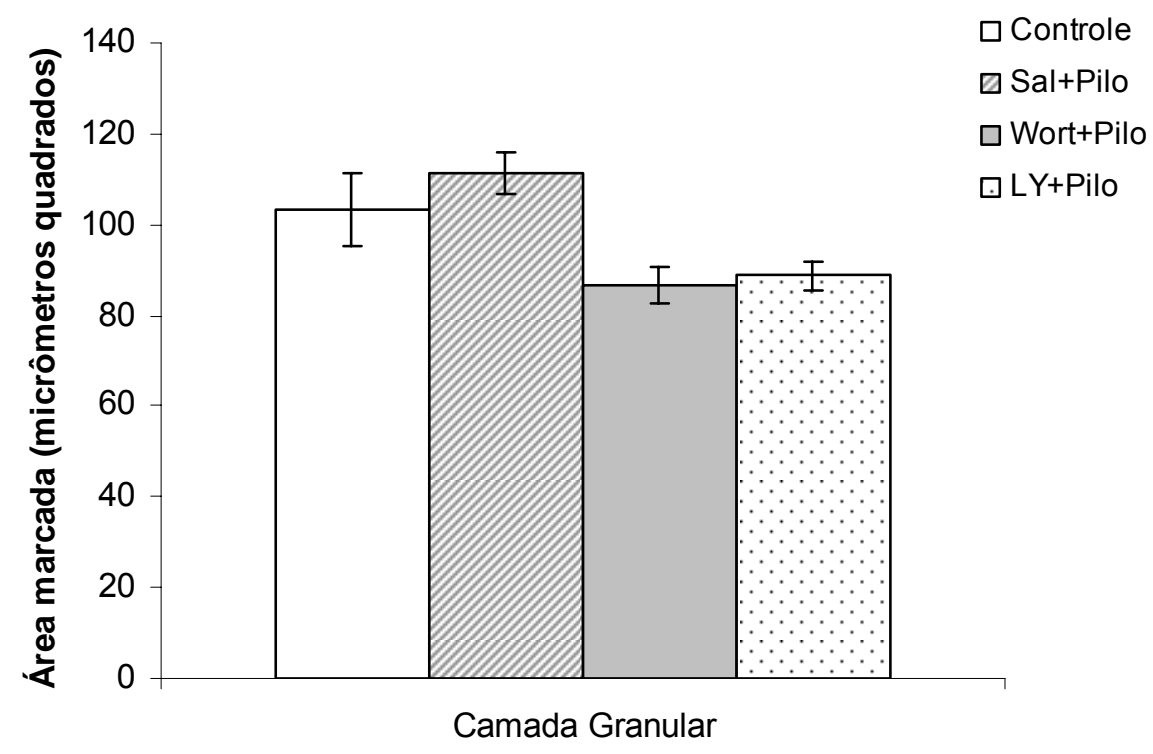

B

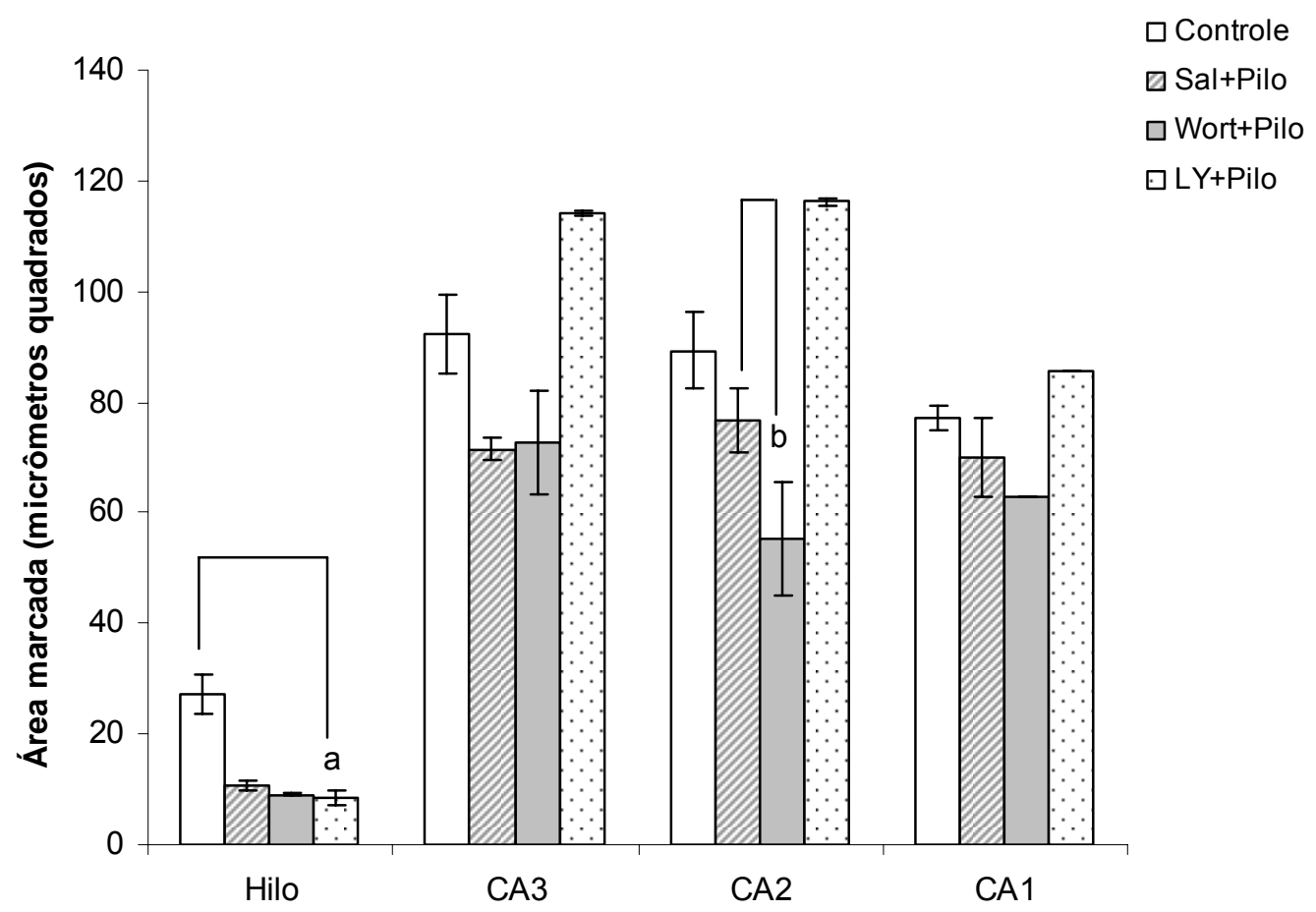

Figura 15: Análise da imunorreatividade para Akt na região posterior do hipocampo nos grupos LY+Pilo, Wort+Pilo, Sal+Pilo e Controle. A: imunorreatividade para Akt na camada granular; B: imunorreatividade para Akt na região do hilo, CA3, CA2 e CA1 do hipocampo; a: $\mathrm{p}=0,022$ (Kruskal-Wallis, pós-teste de Dunn), b: $\mathrm{p}=0,016$ (ANOVA, pós-teste de Bonferroni). 


\subsection{Análise da expressão da Akt para o grupo Sal+Pilo-sobrevida 1 dia e Sal+Pilo- sobrevida 7 dias pós-SE.}

\subsubsection{Sítio de injeção versus lado contralateral}

A imunorreatividade para Akt no grupo de animas Sal+Pilo-sobrevida 7 dia pós-SE evidenciou maior grau de marcação na região do hilo, conforme pode ser observado na Tabela 9 e nas figuras $16 \mathrm{~A}$ e $16 \mathrm{~B}$.

Na camada granular o grupo Sal+Pilo-sobrevida 1 dia pós-SE revelou a tendência estatística de (teste de Mann-Whitney, $\mathrm{p}=0,052$ ). Para os subcampos CA3, CA2 e CA1 nenhuma diferença estatisticamente significante foi encontrada.

Tabela 9: Análise da imunorreatividade para Akt no hipocampo (sítio de injeção versus lado contralateral nos grupos Sal+Pilo sobrevida-1 dia e Sal+Pilo sobrevida-7 dias pós-SE

\begin{tabular}{cccccc}
\hline $\begin{array}{c}\text { Região do } \\
\text { Hipocampo }\end{array}$ & $\begin{array}{c}\text { Grupo } \\
\text { Experimental }\end{array}$ & $\begin{array}{c}\text { Área marcada } \\
\mathbf{\mu m}^{2}\end{array}$ & $\begin{array}{c}\text { Grupo } \\
\text { Controle }\end{array}$ & $\begin{array}{c}\text { Área marcada } \\
\mathbf{\mu m}^{2}\end{array}$ & $\begin{array}{c}\text { Teste } \\
\text { Estatístico* }\end{array}$ \\
hilo & $\begin{array}{c}\text { Sal+Pilo } \\
\text { sobrevida }\end{array}$ & 13 & $\begin{array}{c}\text { Sal+Pilo } \\
\text { sobrevida } \\
\text { 1 dia }\end{array}$ & 10 & $\mathrm{p}=0,033$ \\
\hline
\end{tabular}

*As análises estatísticas foram realizadas comparando a imunorreatividade para Akt do "Grupo Experimental" com aquelas do "Grupo Controle" utilizando o teste t. 
A

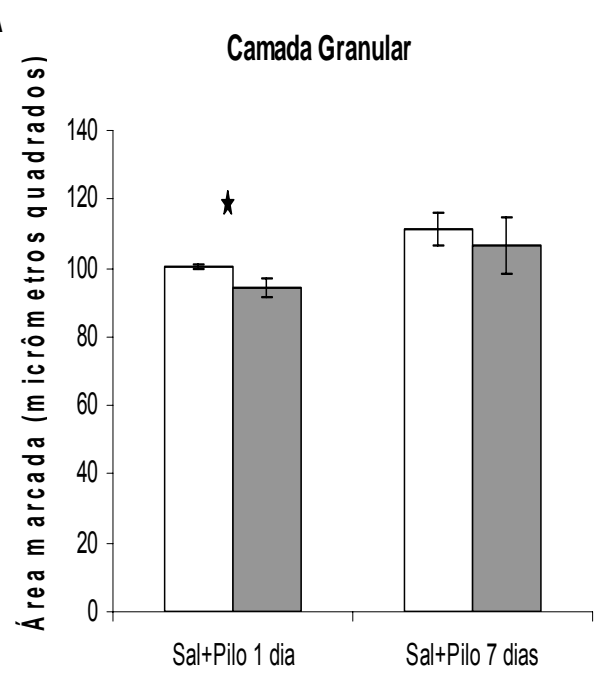

C

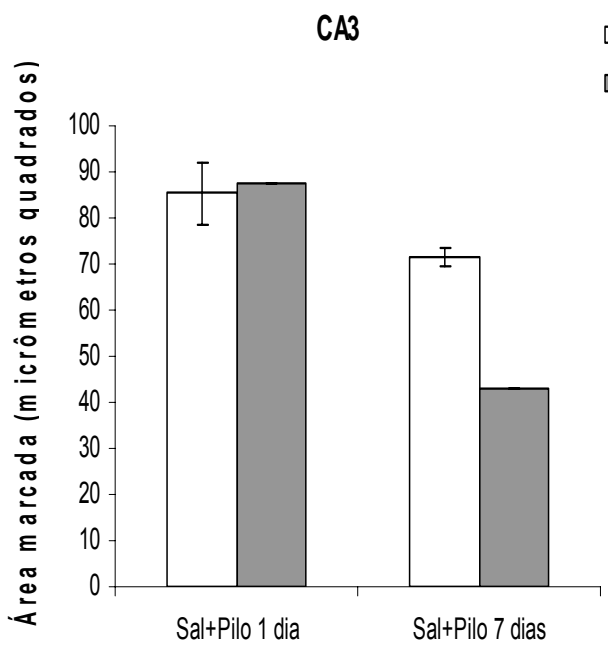

E

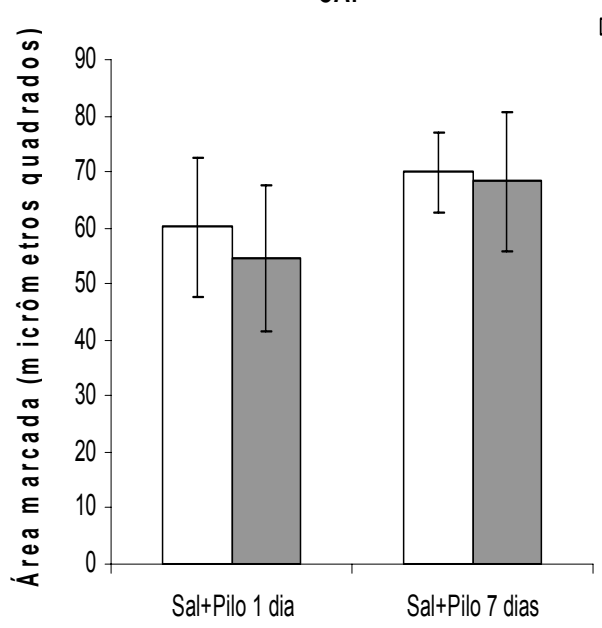

B

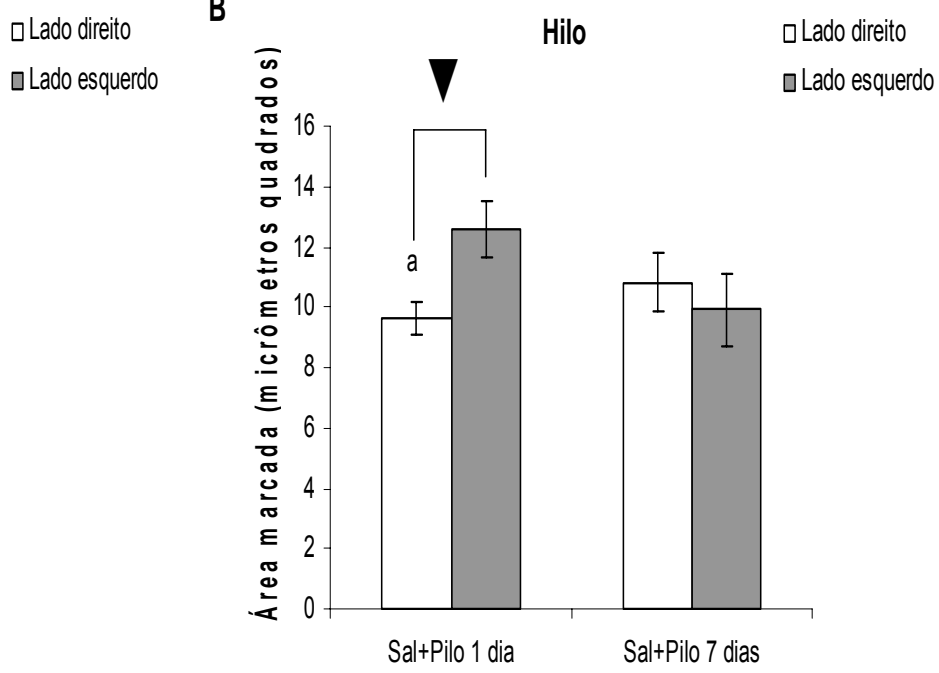

口Lado direito D

口 Lado esquerdo

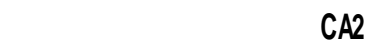

○Lado direito

¿Lado esquerdo

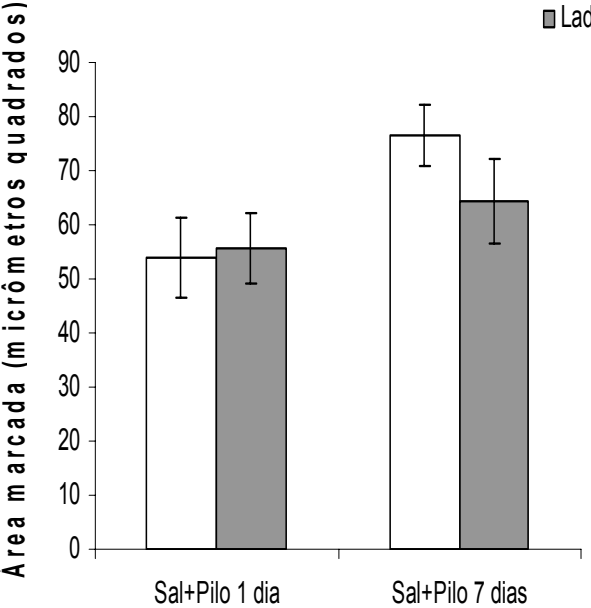

○Lado direito

qLado esquerdo Figura 16: Análise da imunorreatividade para Akt avaliada no hipocampo (sítio da injeção versus lado contralateral) nos grupos Sal+Pilo-sobrevida 1 dia pós-SE e Sal+Pilo-sobrevida 7 dias pós-SE.A:imunorreatividade para Akt na camada granular;

$\star \mathrm{p}=0,052, \mathbf{B}$ : imunorreatividade para Akt na região do hilo a: $\mathrm{p}=0,03$ (teste t), C: imunorreatividade para Akt no subcampo CA3, D: imunorreatividade para Akt no subcampo CA2, D: imunorreatividade para Akt no subcampo CA1. 


\subsubsection{Análise da expressão da Akt no hipocampo (lado ipsilateral à injeção, valores médios entre as regiões anterior, média e posterior)}

A imunorreatividade para Akt no grupo de animas Sal+Pilo-sobrevida 7 dias pós-SE evidenciou maior grau de marcação na camada granular, conforme observado na Tabela 10 e nas figuras $17 \mathrm{~A}$ e $17 \mathrm{~B}$.

A análise do subcampo CA2 revelou uma tendência estatística de (teste $t, p=0,059$ ). Na região do hilo CA3 e CA1 nenhuma diferença estatisticamente significante foi encontrada.

Tabela 10: Análise da imunorreatividade para Akt no hipocampo (lado ipsilateral à injeção, valores médios entre as regiões anterior, média e posterior) nos grupos Sal+Pilo sobrevida-1 dia e Sal+Pilo sobrevida-7 dias pós-SE

\begin{tabular}{cccccc}
\hline $\begin{array}{c}\text { Região do } \\
\text { Hipocampo }\end{array}$ & $\begin{array}{c}\text { Grupo } \\
\text { Experimental }\end{array}$ & $\begin{array}{c}\text { Área marcada } \\
\boldsymbol{\mu m}^{2}\end{array}$ & $\begin{array}{c}\text { Grupo } \\
\text { Controle }\end{array}$ & $\begin{array}{c}\text { Área marcada } \\
\mathbf{\mu m}^{2}\end{array}$ & $\begin{array}{c}\text { Teste } \\
\text { Estatístico* }\end{array}$ \\
$\begin{array}{c}\text { Camada } \\
\text { Granular }\end{array}$ & $\begin{array}{c}\text { Sabrevilo } \\
\text { sobias }\end{array}$ & 107 & $\begin{array}{c}\text { Sal+Pilo } \\
\text { sobrevida } \\
1 \text { dia }\end{array}$ & 100 & $\mathrm{p}=0,047$ \\
\hline
\end{tabular}

\footnotetext{
*As análises estatísticas foram realizadas comparando a imunorreatividade para Akt do "Grupo Experimental"
} com aquelas do "Grupo Controle" pelo teste t. 

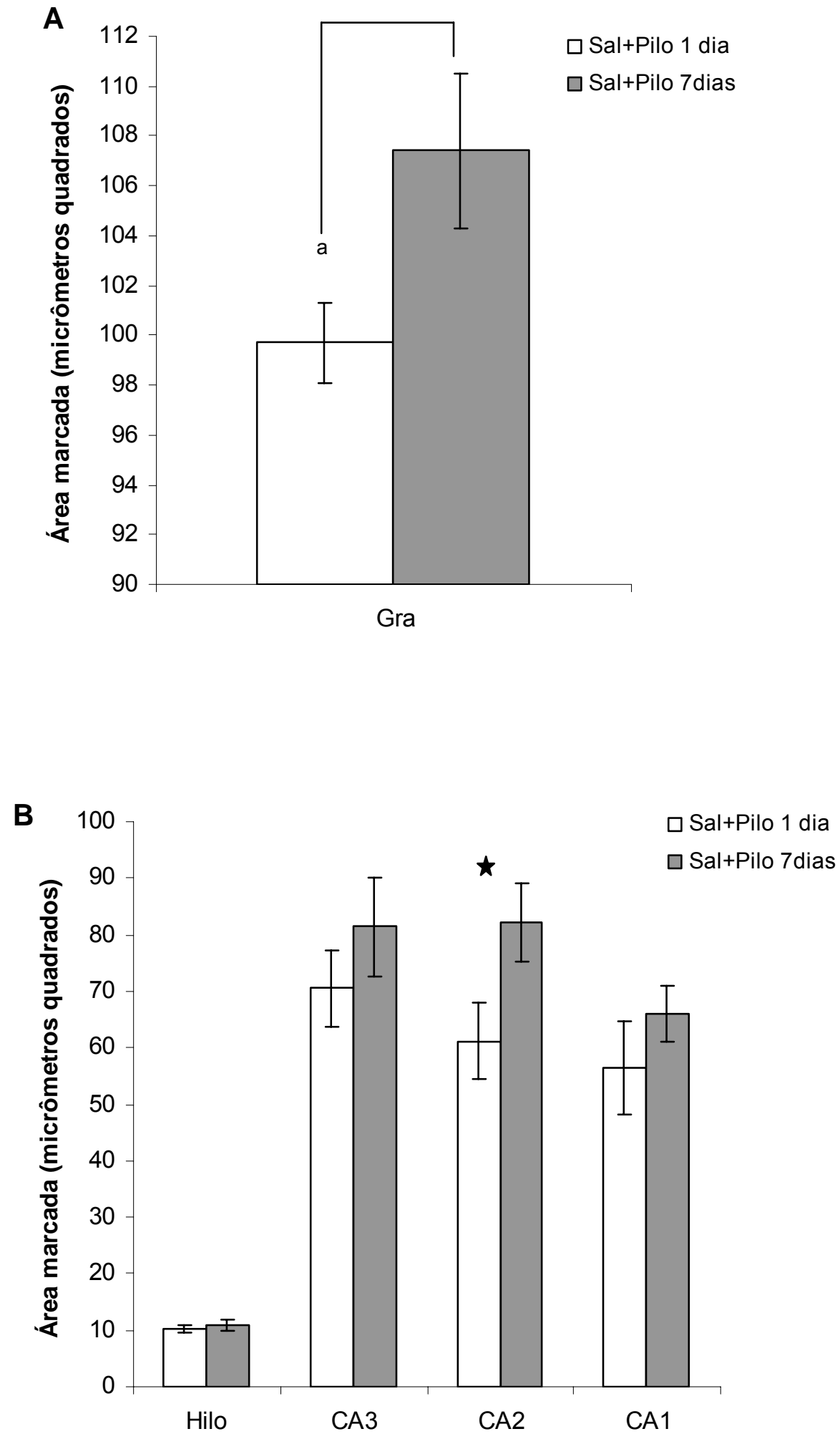

Figura 17: Análise da imunorreatividade para Akt nos vários níveis de formação hipocampal nos grupos Sal+Pilo-sobrevida 1 dia pós-SE e Sal+Pilo-sobrevida 7 dias pós-SE. A: imunorreatividade para Akt na camada granular; a: $\mathrm{p}=0,047$ (teste t); B: imunorreatividade para Akt na região do hilo, CA3, CA2 $(\star \mathrm{p}=0,059$; teste $\mathrm{t})$ e CA1. 

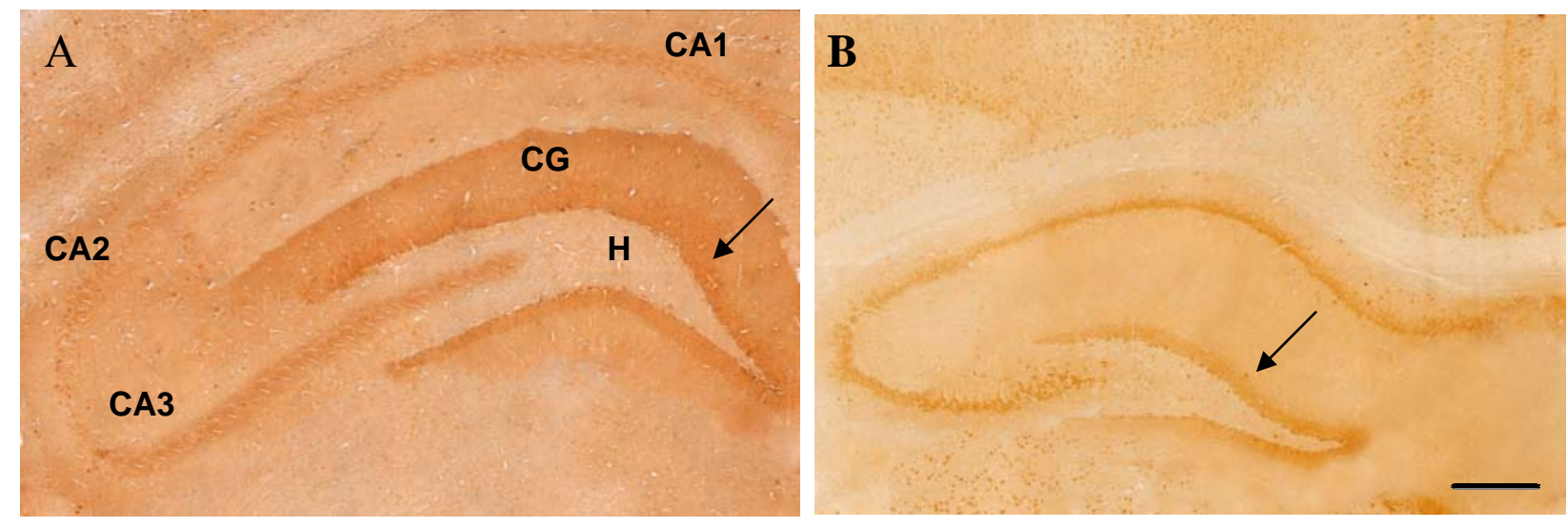

Figura 18: Fotomicrografias de secções coronais dos vários níveis de formação hipocampal, imunomarcada para Akt (lado ipsilateral à injeção da Pilo) nos grupos Sal+Pilo-sobrevida de 1 dia pós-SE (A) e Sal+Pilosobrevida de 7 dias pós-SE (B); CG: camada granular, H: região do hilo;Barra de calibração: $200 \mu \mathrm{m}$.

\subsubsection{Análise do lado ipsilateral à injeção de Pilo, região posterior.}

A imunorreatividade para Akt não revelou diferença estatisticamente significante para a marcação da Akt nos grupos Sal+Pilo-sobrevida 1 dia pós-SE e Sal+Pilo-sobrevida de 7 dias pós-SE em nenhuma das regiões do hipocampo (Figura 18). 

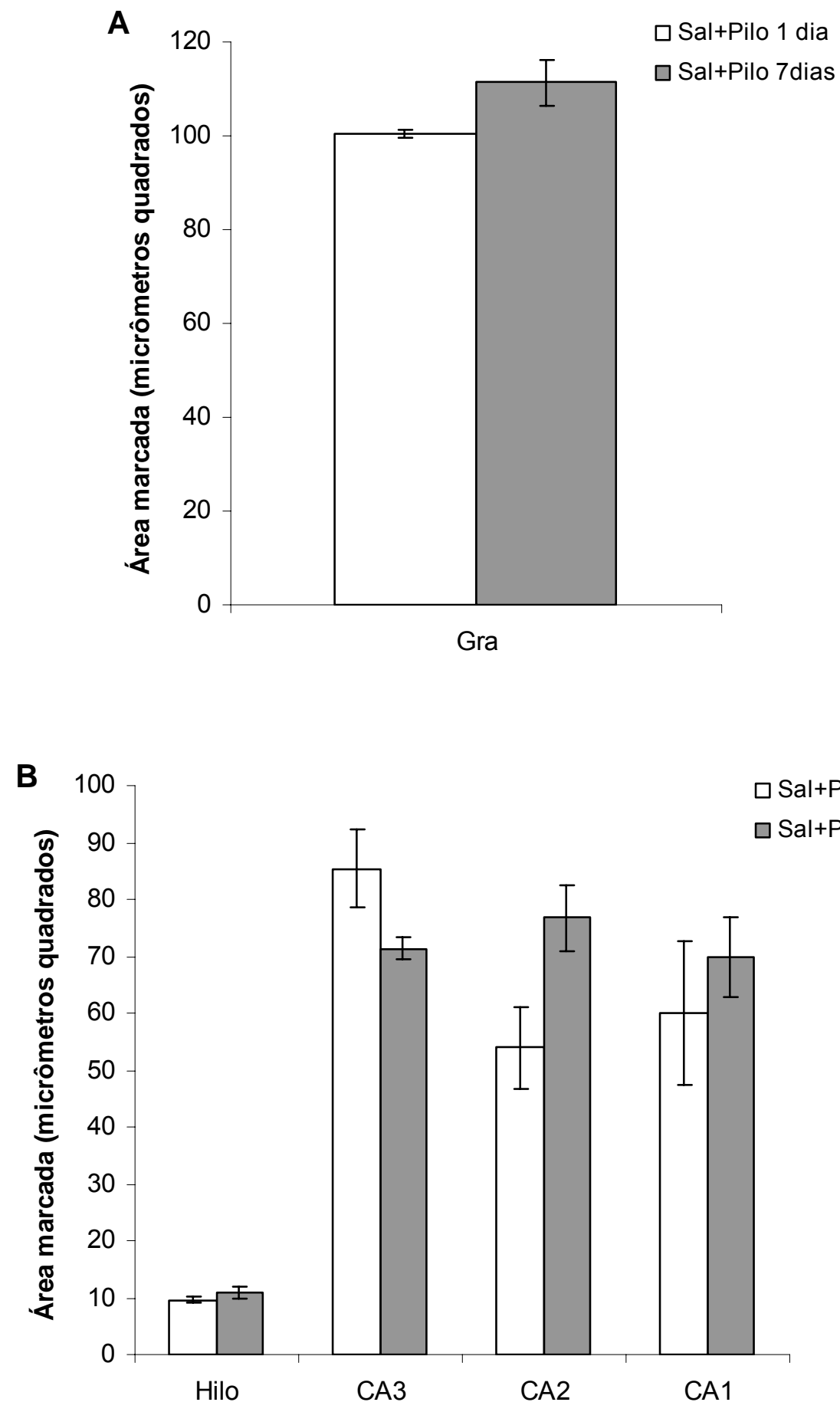

Figura 19: Análise da imunorreatividade para Akt avaliada na região posterior do hipocampo nos grupos Sal+Pilo-sobrevida 1 dia pós-SE e Sal+Pilo-sobrevida 7 dias pós-SE. Nenhuma diferença estatisticamente significante foi encontrada para os grupos estudados. A: imunorreatividade para Akt na camada granular; B: imunorreatividade para Akt na região do hilo, CA3, CA2 e CA1. 
6. DISCUSSÃO 


\section{DISCUSSÃO}

A epilepsia vem afetando mundialmente cerca de 50 milhões de indivíduos e sua predominância (90\% dos casos) está centrada basicamente em países em desenvolvimento (SACONATO et al., 2009; SANDER, 2003). Muito embora existam indicações de que a remissão das crises possa ser alcançada em 70-80\% dos casos (SANDER, 2003), muitos pacientes se tornam refratários aos diferentes processos terapêuticos e continuam sofrendo os efeitos desta desordem neurológica. A continuidade da doença propicia tanto um incremento nos custos financeiros em saúde pública quanto a ocorrência de problemas psicológicos, uma vez que altera a qualidade de vida dos pacientes e de seus familiares.

Assim, o conhecimento dos processos envolvidos na gênese da epilepsia, como por exemplo a excitabilidade neuronial, sinaptogênese, aumento ou diminuição de moléculas endógenas, morte e proliferação celular, regulação transcricional da expressão gênica e transdução de sinais, podem fornecer dados sobre os mecanismos envolvidos na proteção neuronial e possibilitar o desenvolvimento de novas terapias baseadas na ativação de vias neuroprotetoras.

Os processos celulares envolvidos durante a ativação da cascata de sinalização da Akt exercem um papel fundamental na sobrevivência celular pós-insulto; vários estudos têm revelado que esta cascata de sinalização pode ser ativada por diversos estímulos químicos, como, por exemplo, na presença de câmara anaeróbica utilizada para avaliar o tratamento isquêmico em culturas de astrócitos (JIANG, Z. et al., 2003b), na presença de quemoquina RANTES (proteína identificada durante o processo inflamatório de artrite reumatóide para a avaliação da quimiotaxia em cultura de neutrófilos) (FERRANDI et al., 2007), na presença de canabinoides envolvidos com neuroproteção em modelos animais (OZAITA et al., 2007) e no modelo experimental de epilepsia induzido por Pilocarpina (GOTO et al., 2010). Segundo o estudo de Luo e colaboradores (LUO et al., 2003), a desativação da cascata de sinalização, em 
cultura neuronial, promove a morte celular em modelos expostos à neurotoxicidade mediada por N-metil-D-aspartato (NMDA), assim como em células HeLa, PC12 e Jurkat T, tratadas com óxido nítrico e irradiação UVB. Noshita e colaboradores (2001) também demonstraram que após a indução de isquemia cerebral em camundongos, um aumento da Akt fosforilada pode ser observado no córtex cerebral desses animais, enquanto o bloqueio da via de PI3K e a inibição da Akt poderiam ser os responsáveis pelo dano celular ao DNA.

Tendo em vista o papel neuroprotetor da cascata de sinalização da Akt e o efeito excitotóxico observado em modelo experimental de epilepsia induzido por Pilocarpina, o objetivo principal do nosso trabalho foi modular a expressão da Akt nas alterações patológicas no hipocampo de ratos na fase aguda pós-SE por intermédio da utilização de inibidores farmacológicos da fosfatidilinositol-3-cinase (PI3K).

De acordo com os resultados encontrados, após microinjeção de Pilocarpina intrahipocampal, verificou-se que cerca de $42 \%$ dos animais tratados com LY+Pilo, Wort+Pilo e Sal+Pilo, entraram em $S E$ e apresentaram movimentos faciais, incluindo automatismos mastigatórios (associados à salivação), tremores generalizados e piloereção. Aproximadamente 20 minutos após o início da movimentação, o comportamento progrediu para hiperssalivação, crises motoras límbicas, clonia das patas anteriores, elevação e queda do animal. Considerando os efeitos excitotóxico da Pilocarpina no modelo de $S E$, é possível inferir que a intensidade do insulto pode ter modificado a via de sinalização da Akt e, por sua vez, alterado o perfil de neuroproteção, proliferação e sobrevivência celular.

Alguns estudos indicam que a administração do agonista colinérgico, Pilocarpina, induz uma série de alterações eletrográficas e comportamentais indicativas de SE (FURTADO et al., 2002; TURSKI, W. A. et al., 1984). As alterações eletrográficas ocorrem, na maioria dos estudos, precedendo as crises comportamentais, sendo que em algumas ocasiões os animais podem não manifestar comportamento ictal. Embora não tenha sido realizado o 
monitoramento eletroencefalográfico (EEG) dos animais, levantando a hipótese que um número maior de animais poderiam ter entrado em $S E$ e não identificados pelo método visual, as conclusões deste estudo, muito provavelmente, não mudariam, uma vez que não existiu diferença significativa entre os grupos tratados com injeções de inibidores e aqueles tratados somente com Pilocarpina.

A taxa de mortalidade de animais pós indução de $S E$ foi de 5,6\% para os grupos LY+Pilo e Sal+Pilo e de 4,2\% para o grupo Wort+Pilo. Os grupos LY+Pilo e Wort+Pilo apresentaram 4,2\% de remissão espontânea das crises autossustentadas, enquanto este índice foi de 5,6\% para o grupo Sal+Pilo. No entanto, não foram observadas diferenças estatisticamente significantes entre a mortalidade e a remissão espontânea das crises autossustentadas; isto se deu talvez pela complexidade dos modelos experimentais in vivo ou pela resposta produzida pelos diferentes grupos de animais de acordo com intensidade do insulto.

Verificou-se que o tempo médio de latência para o início do $S E$ foi maior no grupo Wort+Pilo, 42 minutos, quando comparado com o grupo Sal+Pilo, 24 minutos. Este resultado sugere que a ação da Wortmanina, promova a inibição da PI3K, a qual inibe a fosforilação da Akt e, com isto, prolongue o tempo de latência para o início da crise em oposição aos animais tratados somente com Pilocarpina. É provável que a ação da Wortmanina $(0,25 \mathrm{mM})$, apresente maior afinidade sobre PI3K quando comparada ao inibidor LY294002 (100 mM). De acordo com o estudo de Wymann e colaboradores (1996), a Wortmanina, em concentração nanomolar, é um potente inibidor de PI3K in vitro; o caráter de ligação covalente da Wortmanina pode explicar a eficácia deste inibidor sobre a enzima PI3K. Para o nosso estudo, é possível que a Wortmanina, mesmo em doses baixas, possa ser mais efetiva quando comparada ao LY294002. Na verdade, o LY294002 é identificado como um inibidor competitivo do sítio de ligação do ATP da enzima PI3K, enquanto a Wortmanina foi 
classificada como um inibidor não competitivo em relação a este mesmo sítio. Entretanto, de acordo com o estudo de Wymann e colaboradores (1996), a Wortmanina reage covalentemente para o sítio de ligação do ATP, produzindo características semelhantes a de um inibidor aparente não-covalente, neste caso, reduzindo a atividade funcional da enzima PI3K e tornando esta enzima não reativa e inalterável. Deste modo, é possível que a Wortmanina iniba a PI3K de forma mais efetiva que o LY294002, gerando uma resposta tardia para a evolução das crises convulsivas nesses animais.

Para a avaliação dos padrões de perda celular, no modelo experimental de $S E$ induzido por Pilocarpina, vários marcadores são utilizados para confirmar o padrão de morte neuronial, como por exemplo o NeuN (anti-núcleo neuronal), o Fluoro- Jade (FJ) e o TUNEL (do inglês terminal deoxynucleotidyl transferase-mediated biotinylated UTP nick in labeling); este último como um indicador de apoptose (KUBOVA et al., 2001; LEMAIRE et al., 2000; SANKAR et al., 1997). Neste estudo, NeuN foi utilizado por ser um marcador específico de neurônios, permitindo assim uma melhor estimativa da densidade neuronial e a identificação de regiões ou subregiões nas quais se observa um número reduzido de células positivas para NeuN.

Considerando que o DMSO foi utilizado como veículo dos inibidores farmacológicos, LY294002 e Wortmanina, procuramos avaliar primeiramente a toxicidade celular e a interferência desta substância na cascata de sinalização da Akt. Para tal, a densidade celular neuronal foi mensurada após injeção de DMSO $(12,8 \%)$ ou Salina $(0,9 \%)$ e nenhuma alteração tecidual foi observada no hipocampo ipsilateral, além das alterações mecânicas da cânula, o que nos permite indicar que o uso do DMSO foi realizado de forma segura neste estudo. Esta capacidade do DMSO interagir com outras drogas produzindo toxicidade celular já foi estudada por Brayton (1986), sendo indicada uma toxicidade muito baixa. Outros autores (OZAITA et al., 2007) reportaram que o uso da Wortmanina, tendo como veículo o 
DMSO, na concentração de $25 \%$ e injetado em camundongos pela via intracerebroventricular (icv), parece não produzir efeitos na fosforilação da Akt, comparado àqueles animais tratados com Salina $(0,9 \%)$. Sendo assim, pode-se afirmar que o uso do DMSO como diluente dos inibidores de fosfatidilinositol-3 cinase, em resposta a sua elevada segurança e a sua baixa toxicidade, não interfere nos níveis de fosforilação da cascata sinalização da Akt.

Também foi avaliada a densidade celular nos hipocampos ipsilaterais de animais com sobrevida de 7 dias pós-SE e injetados com LY+Pilo ou Wort+Pilo ou Sal+Pilo versus a densidade celular nos hipocampos contralaterais, locais onde somente o veículo foi injetado. De acordo com os resultados encontrados, as regiões do hilo e de CA3 apresentaram perda neuronial significativa no grupo LY+Pilo. Dada a maior perda celular neste grupo, podemos concluir uma maior suscetibilidade da região do hilo, bem como da região CA3, à ação direta desta droga injetada no hipocampo, por apresentarem células altamente vulneráveis à agressões. Em modelos experimentais de epilepsia, as células hílares são uma das primeiras populações neuroniais do hipocampo a morrer, tal perda na região do hilo parece correlacionar-se com a extensão do brotamento de fibras musgosas (BFM), sendo as células musgosas mais suscetíveis a morte celular (BABB et al., 1984b; SLOVITER, 1987). No estudo de Horn e colaboradores (2005) foi observado que o uso de LY294002, em células organotípicas do hipocampo de ratos, pode inibir PI3K e que, por sua vez, inibe a cascata de sinalização da Akt, induzindo morte neuronial no subcampo CA1 e no giro denteado (GD), sendo sugerido que a inibição da via de PI3K pode ser importante para a resistência e a sobrevivência destas regiões.

A densidade celular avaliada no lado ipisilateral para as várias regiões do hipocampo (anterior, média e posterior) e somente na região posterior foi outro parâmetro analisado. Os resultados provenientes da comparação indicaram que a região do hilo apresentou menor 
densidade neuronial no grupo Sal+Pilo, seguido pelos grupos LY+Pilo, Wort+Pilo e grupo Controle.

Como já bem descrito na literatura, sabe-se que a PI3K é uma importante enzima para sinalização intracelular da Akt e inibidores desta enzima, tais como o LY294002 e a Wortmanina, têm o papel de bloquear os eventos downstream da fosfatidilinositol-3-cinase e, por sua vez, impedir a fosforilação da proteína Akt (BRUNN et al., 1996; ORCY et al., 2008; POWIS et al., 1994). Todavia, baseando-se nos resultados relacionados à menor densidade neuronial para o grupo Sal+Pilo, sugerimos que os inibidores farmacológicos não inibiram PI3K e, consequentemente, não modificaram a via da Akt como esperado. Na hipótese inicial de trabalho, esperar-se-ia que o uso dos inibidores da fosforilação da Akt, LY294002 e Wortmanina, revelassem um maior padrão de perda celular quando comparado com o grupo de animais tratados somente com Pilocarpina, confirmando, assim, a desativação da enzima PI3K e da fosforilação da proteína Akt frente ao insulto epileptogênico, algo não confirmado pelo presente estudo. Os resultados também sugerem que a região do hilo, em todas as secções (desde aquela do hipocampo dorsal até o mais ventral), foi o local mais suscetível e vulnerável aos danos excitotóxicos da Pilo, com ou sem associação de outras drogas. Essa perda parece relacionar-se com a liberação de aminoácidos excitatórios e sua interação com a membrana dos elementos pós sináptico vulneráveis, pois na lesão epiléptica a ativação dos canais de cálcio $\left(\mathrm{Ca}^{++}\right)$pelos aminoácidos excitatórios determina seu influxo nos elementos celulares com alta densidade para estes canais, alterando a homeostase intracelular. Neste sentido, este fenômeno pode ser uma explicação para a lesão celular na formação hipocampal encontrado no modelo experimental de $S E$ induzido por Pilocarpina (SCORZA et al., 2009). De acordo com Turski (1989), estudos morfológicos do encéfalo pós $S E$ demonstraram morte celular no complexo amigdalar, núcleo talâmico, córtex entorrinal e neocórtex, assim como no hipocampo nas regiões CA1, CA3 e hilo do giro denteado. Tais estudos também indicaram 
perda de axônios, reação glial, brotamento supragranular de fibras musgosas das células granulares do giro denteado, assim como a dispersão das células granulares (CAVALHEIRO, 1995; MELLO et al., 1992). De acordo com Sloviter (1994), a perda de células musgosas no hilo do giro dentado ocorre algumas horas após uma lesão quer seja através de estimulação elétrica da via perfurante ou em modelos de ácido caínico. Portanto, é provável que, após a indução do $S E$ por Pilocarpina, a região do hilo apresente modificações homeostásicas intracelulares decorrentes tanto da injeção do agonista colinérgico como da injeção dos inibidores farmacológicos, tornando a região hilar mais predisposta a um maior padrão de perda celular.

De acordo com a hipótese inicial de trabalho, os animais tratados com os inibidores farmacológicos da fosforilação da Akt, deveriam apresentar maior padrão de degeneração neuronial quando comparado aos animais tratados com Sal+Pilo. É possível que o LY294002 (na concentração de $100 \mathrm{mM}$ ) e a Wortmanina (na concentração de $0,25 \mathrm{mM}$ ) possam não ter inibido diretamente a PI3K. As características farmacológicas da Wortmanina demonstram que esta droga é um inibidor irreversível não competitivo de PI3K, cuja inativação é classificada como tempoconcentração dependente (POWIS et al., 1994), enquanto o LY294002 é considerado um inibidor reversível desta mesma enzima, muito embora, suas propriedades farmacológicas não tenha sido muito bem descritas ainda pela literatura (BRUNN et al., 1996). Entretanto, de acordo com os nossos resultados, é provável que a intensa ativação colinérgica determinada pela Pilo tenha ativado outras vias de sinalização e interagido com várias outras moléculas que tenham a capacidade de aumentar ou diminuir a excitabilidade dos circuitos hipocampais ou moléculas que, por ventura, participem de processos neuroprotetores. É sabido que o neuropeptídeo Y em modelos experimentais de epilepsia encontra-se aumentado em subrregiões específicas hipocampais, sendo capaz de regular a exicitabilidade neuronial e reduzir a intensidade das crises (SORENSEN et al., 2009; 
VEZZANI et al., 1999). Assim, a participação de outras moléculas endógenas e a ativação de múltiplos sinais intra e extracelulares podem ter interferido na observação de efeitos decorrentes da inibição da cascata da Akt, frente a um insulto epileptogênico.

Vários estudos demonstram o papel da Akt na regulação do metabolismo e captação da glicose (BRAZIL e HEMMINGS, 2001; FAYARD, B. et al., 2005a; KOHN et al., 1996), na síntese de proteínas envolvidas no processo apoptótico (CARDONE et al., 1998; COFFER et al., 1998; DATTA e DATTA, 1999; DOWNWARD, 1998; KIM et al., 2001; YUAN e YANKNER, 2000), no controle da angiogênese (BRAZIL e HEMMINGS, 2001; DIMMELER e ZEIHER, 2000; MANNING e CANTLEY, 2007) e no mecanismo de sobrevivência, crescimento e proliferação celular (ENGELMAN et al., 2006; GOTTLIEB et al., 2002; MANNING e CANTLEY, 2007; MAYO e DONNER, 2001; SONG et al., 2005; YANG et al., 2004); portanto, embora os achados do presente trabalho revelem que os grupos que receberam injeções intra-hipocampais de inibidores farmacológicos da Akt antes da indução do $S E$ tenham exibido menor padrão de perda neuronial nas várias regiões do hipocampo, não é possível descartar a hipótese da Akt estar participando ativamente no processo de neuroproteção pós insulto induzido pelo $S E$, uma vez que existem dados suficientes na literatura indicando que o estado de fosforilação é importante para a sobrevivência celular. No entanto, não foi possível encontrar efeitos para o desenho experimental e o modelo por nós adotados não proporcionou a investigação por completo do papel da Akt no insulto epileptogênico.

De acordo com Eng e colaboradores (1994), após a ocorrência de um dano no Sistema Nervoso Central (SNC) provocado por uma doença, trauma ou insulto químico, ocorre um fenômeno conhecido como astrogliose, o qual é caracterizado por um aumento acentuado do número de astrócitos na região do insulto, levando a uma produção expressiva da proteína GFAP (do inglês glial fibrillary acid protein). Em pacientes com Epilepsia do Lobo Temporal 
(ELT), a proliferação glial é um achado proeminente no hipocampo associado à esclerose hipocampal que, por sua vez, refere-se a uma perda neuronial seletiva nos subcampos CA1, CA3 e região do hilo, sendo as células granulares do giro denteado e as células piramidais da região de CA2 as mais preservadas (MELDRUM et al., 1992; NISHIO et al., 2000). A gliose reativa é caracterizada por uma proliferação e hipertrofia de corpos celulares gliais em resposta a uma variedade de lesões no $\mathrm{SNC}$, as quais expressam um aumento nos níveis de proteína GFAP no local da lesão (LI et al., 1995). É observada uma maior expressão desta proteína no hipocampo e outras estruturas, como neócortex, tálamo e amígdala, em modelo experimental de epilepsia induzido por Pilocarpina 60 dias após o episódio de $S E$. No entanto, estas alterações podem ocorrer de forma heterogênea e as diferenças podem ser associadas à frequência de crises espontâneas (GARZILLO e MELLO, 2002).

No intuito de se avaliar os efeitos do bloqueio da cascata da Akt, assim como o efeito do $S E$ sobre as alterações patológicas no hipocampo de ratos, decidimos por utilizar marcadores específicos para células gliais (anticorpos anti-GFAP) para avaliar o nível de astrogliose e visualizar a extensão da lesão tecidual após o insulto epileptogênico.

No presente estudo, a astrogliose foi um achado observado na região da camada granular nos animais do grupo LY+Pilo quando comparado com o grupo Sal+Pilo e Controle nos vários níveis da formação hipocampal. Segundo Kralic e colaboradores (2005), foi observado que, no modelo de ácido caínico, a região com maior formação de astrogliose foi a camada subgranular, localizada próxima a gênese das crises. De fato, a síntese de GFAP é aumentada quando os astrócitos são ativados em resposta a uma situação de estresse (lesão) ou aumento anormal da atividade neuronial (HANSEN et al., 1990). Em modelos animais induzidos ao $S E$ por Pilocarpina já é bem documentado que alterações neuropatológicas, tais como lesão tecidual e perda celular, são decorrentes dos efeitos excitotóxicos produzidos pelo próprio agonista colinérgico (SCORZA et al., 2009). Assim, como toda lesão tecidual induz 
respostas inflamatórias, é possível inferir que os efeitos sobre determinado tecido dependem da intensidade do estímulo. A inflamação pode ser benéfica em algumas situações, onde citocinas e quimiocinas podem induzir efeitos neuroprotetores, mas pode ser prejudicial em outras ocasiões, induzindo à morte celular.

Os estudos de Hansen e colaboradores (1990) também corroboram os achados referentes ao efeito do kindling hipocampal e dos marcadores gliais, nos quais foram observados um aumento de GFAP e de enolase neurônio-especifíca nas regiões do hipocampo, córtex piriforme e amígdala, indicando, respectivamente, a presença de gliose reativa e aumento do metabolismo anaeróbico. Neste caso, sugere-se que o grupo que recebeu o LY294002 pode revelar uma lesão tecidual na camada granular, promovendo alterações celulares que culmine em morte celular em decorrência do estímulo. Portanto, é provável que o maior grau de astrogliose, na camada granular, para o grupo LY+Pilo seja decorrente da lesão tecidual induzida pelo insulto epileptogênico e, por sua vez, um maior número de astrócitos positivos tenha sido detectado contra o anticorpo anti-GFAP. Mello e colaboradores (1992), no estudo experimental com ratos adultos epilépticos após indução de $S E$ por Pilocarpina, indicaram uma dispersão das células granulares em decorrência da perda neuronial induzida pelas crises epilépticas. A dispersão das células granulares é caracterizada pela perda de justaposição habitual das células granulares do giro denteado, produzindo aumento da sua espessura e dos espaçamentos intercelulares. Tal dispersão celular, em pacientes com ELT, é também observada na esclerose hipocampal e está associado à perda neuronial (EL BAHH et al., 2001; HOUSER, 1990). Este fato nos sugere que, devido à maior astrogliose apresentada pelo grupo LY+Pilo, tal dispersão também é provavelmente encontrada na camada granular destes animais.

Em relação à análise dos lados ipsilateral (sítio de injeção da droga) quando comparado ao lado contralateral e região posterior do hipocampo, o grupo de animal que 
recebeu o pré-tratamento com a droga LY+Pilo e o grupo Sal+Pilo, não revelaram diferenças na resposta astrocitária. Em tese, esperar-se-ia um grau maior de astrogliose para o grupo tratado com LY294002; no entanto, não foi possível detectar tal aumento. De acordo com o estudo de Sofroniew (2009), sabe-se que as características da astrogliose reativa podem variar conforme a severidade do dano, o que inclui alterações celulares, hipertrofia celular progressiva e a proliferação celular. Estas mudanças poderiam ser moduladas através de vias de sinalização, as quais culminariam em respostas astrocitárias modificadas, ou seja, estimulação da produção de moléculas pró e anti-inflamatórias ou daquelas que poderiam aumentar ou reduzir o estresse oxidativo, de acordo com o contexto da lesão (SOFRONIEW, 2009).

Até o presente momento, não há relatos conhecidos na literatura sobre estudos envolvendo os efeitos na astrogliose hipocampal em ratos pré-tratados com inibidores farmacológicos da Akt antes da indução de $S E$. Pelos achados do presente trabalho, foi confirmado que o grupo tratado com LY294002, no período de 7 dias, apresentou uma resposta inflamatória local, quando comparado com o grupo que recebeu injeção de Pilocarpina; porém, é questionável se o período de 7 dias é um tempo suficiente para a quantificação da proteína glial. De acordo com Ceresér e colaboradores (2006), animais induzidos à convulsão, após um único choque elétrico convulsivo, podem apresentar redução da expressão de GFAP no hipocampo no período de 48 horas, e este efeito seria sustentado por, pelo menos, até 7 dias após o estímulo. Além disso, segundo Tsankovsa e colaboradores (2004), tal decréscimo na expressão de GFAP, na região hipocampal, poderia ser uma resposta adaptativa da expressão gênica causada pelo eletrochoque. Ceresér e colaboradores (2006) também demonstraram que a expressão de GFAP pode retornar a níveis basais após eletrochoques convulsivos repetitivos (crônicos), sugerindo que o eletrochoque crônico pode 
ter diferentes efeitos sobre a atividade gênica da GFAP em relação aqueles produzidos por uma descarga realizada de forma aguda.

Segundo o estudo de Hausmann e colaboradores (2000), foi observado que pacientes com contusão cortical decorrente de trauma craniano fechado ocorre um aumento significativo do número de células astrogliais GFAP positivas em regiões próximas à lesão cortical no período entre uma e quatro semanas após a injúria. Neste caso, um aumento de GFAP pode ser devido tanto à migração de astrócitos positivos vizinhos à lesão quanto a proliferação acentuada da população de astrócitos locais (AJTAI e KALMAN, 1998).

De acordo com as informações acima descritas, é possível inferir que a severidade do insulto epileptogênico induzido através da administração da Pilocarpina, com ou sem a adição do inibidor farmacológico, tenha revelado um caráter abrangente, dificultando a detecção de diferenças significativas para a astrogliose. No entanto, sugere-se que, em resposta à intensidade do insulto, lesões teciduais podem estar associadas ao mecanismo de morte celular por apoptose ou necrose. No SNC, morte celular por apoptose é observada durante todo o processo de desenvolvimento no qual ocorre a condensação da cromatina, preservação da integridade da membrana plasmática e fragmentação internucleossomal sem danos lesionais maiores, tal como a inflamação. Porém, casos de morte celular por necrose são observados em lesões excitotóxicas, lise celular, fragmentação do DNA e inflamação tecidual (OLNEY, 1994; TAKANO et al., 1991; WYLLIE et al., 1980). Em modelos animais expostos à excitotoxicidade por mecanismos químicos ou físicos no SNC é provável que possa ocorrer um processo contínuo entre morte celular por apoptose e necrose tecidual (PORTERACAILLIAU et al., 1994).

Alguns estudos demonstram que o tempo de avaliação para reação astrocitária em modelos experimentais de epilepsia induzidos por Pilocarpina ou abrasamento elétrico ocorre no período entre 30 e 60 dias na região do hipocampo (GARZILLO e MELLO, 2002; 
VEZZANI e GRANATA, 2005). Para o nosso estudo, é possível que o período de 7 dias não tenha sido um período ideal para uma marcação exuberante astrocitária e, neste caso, períodos tardios poderiam favorecer a astrogliose e permitir uma melhor estimativa de astrócitos positivos no local da lesão.

Inúmeros achados já foram descritos na tentativa de elucidar os mecanismos celulares e moleculares envolvidos em crises epilépticas, seja em tecido epiléptico humano, obtido após remoção cirúrgica (ENGEL et al., 1989; GOLDRING et al., 1992), quanto em tecidos cerebrais de animais submetidos ao status epilepticus em estudos experimentais (BERTRAM, 2007; CLIFFORD et al., 1987; LEITE e CAVALHEIRO, 1995). Sabe-se que crises epilépticas são iniciadas por distúrbios epileptogênicos e fatores endógenos ou exógenos são responsáveis por evocar a atividade epiléptica cerebral em determinado período de tempo. Neste caso, é interessante notar que vias como a de morte celular (por apoptose ou necrose), reorganização axonial, inflamação e astrogliose são participativas nesses insultos e também podem participar de maneira secundária nas crises recorrentes. Portanto, é possível inferir que distúrbios epileptogênicos e/ou fatores precipitantes, podem induzir alterações em determinadas vias moleculares, e estas, eventualmente, podem interferir na circuitaria cerebral, culminar em crises epilépticas e contribuir para a progressão das crises (GITAI et al., 2008). Desta maneira, a identificação de mecanismos moleculares, celulares e neuroquímicos torna-se essencial para a compreensão dos processos epileptogênicos e abre perspectivas para o entendimento das vias de neuroproteção

Muitos estudos têm identificado a cascata de sinalização da Akt como um fator-chave na proteção contra a morte celular (LAWLOR e ALESSI, 2001; LEE et al., 2006; LUO et al., 2003), sendo bem documentado que a Akt promove a sobrevivência celular frente ao estresse oxidativo ou exposição a radicais livres (CHONG et al., 2003; KANG e HENSLE, 2003; MATSUZAKI et al., 1999), favorece proteção contra o peptídeo $\beta$-amilóide (WICK et al., 
2002), protege contra danos ao DNA (HENRY et al., 2001), participa da sobrevivência em pré-condicionamento hipóxico (WICK et al., 2002), tem efeito neuroprotetor em modelos de isquemia cerebral global e focal (JANELIDZE et al., 2001; NAMURA et al., 2000; OUYANG et al., 1999; YANO et al., 2001; YOSHIMOTO et al., 2001) e sobrevivência de neurônios (CROWDER e FREEMAN, 1998). Assim, técnicas como de western blot ou ensaio imuno-histoquímico permitem a detecção da forma fosforilada e não fosforilada da Akt e identificam a sua participação nos diferentes mecanismos celulares (JIANG, K. et al., 2003a; OZAITA et al., 2007; THIMMAIAH et al., 2005). Em nosso estudo, a utilização da análise imuno-histoquímica para Akt foi capaz de mostrar exatamente a distribuição e a localização dos componentes celulares (antígenos) por intermédio da reação com anticorpo (anti-Akt) no hipocampo.

Inicialmente, foi realizado o ensaio imuno-histoquímico contra a Akt ativa (fosforilada) com o objetivo de quantificar os seus níveis e avaliar o padrão de atividade desta proteína frente ao insulto epileptogênico. No entanto, dificuldades metodológicas na padronização da diluição para o anticorpo e quantidade insuficiente de fosfo-Akt dificultaram as análises para a forma fosforilada, sendo realizada apenas a marcação para Akt total.

No presente trabalho, foi investigado como o pré-tratamento com os inibidores LY294002 e Wortmanina poderiam modular a via da Akt após a indução do $S E$, sugerindo a participação desta proteína como agente neuroprotetor. Para tal linha de investigação, optouse por utilizar o anticorpo contra a Akt (pan), que permite a marcação dos níveis totais desta proteína, ou seja, da forma fosforilada e não fosforilada da Akt.

Em primeira análise, os animais de sobrevida-7 dias pós-SE do grupo LY+Pilo, Wort+Pilo e Sal+Pilo não revelaram expressão diferenciada para a proteína no lado ipsilateral ao sítio da injeção da droga quando este foi comparado com o lado contralateral. De acordo com o papel dos inibidores, o bloqueio de PI3K inibiria a fosforilação da Akt; portanto, os 
níveis da Akt total seriam os mesmos da Akt em condições basais. Consistente com estes achados, Luo e colaboradores (2003) testaram o papel dos inibidores LY294002 e Wortmanina em culturas hipocampais de camundongos e demonstraram a inibição de PI3K sobre a Akt, revelando que os níveis da Akt total se mostraram inalterados. Em tese, esperarse-ia que para o grupo tratado somente com a Pilocarpina, o insulto epileptogênico poderia promover a ativação da PI3K que, por sua vez, ativaria a Akt e maiores níveis de expressão da Akt total seriam detectados no sítio da injeção da droga.

Uma comparação entre as várias regiões do hipocampo (anterior, média e posterior) e somente da região posterior revelaram que nos grupos LY+Pilo e Wort+Pilo a região do hilo foi o local de menor expressão da Akt total. Segundo o protocolo experimental adotado, nosso objetivo foi avaliar a modulação da expressão da Akt no modelo experimental de epilepsia induzido por Pilocarpina, bem como os efeitos dos bloqueios desta cascata sobre as alterações patológicas observadas no hipocampo. Como neste estudo foi observada uma menor expressão da Akt total, sugere-se que tal redução seja decorrente de uma maior perda neuronial, na região do hilo, em resposta ao insulto epileptogênico.

Do ponto de vista anatomopatológico, a indução de $S E$ através da administração de Pilocarpina é capaz de promover perda neuronial e astrogliose semelhantes à esclerose hipocampal observada em pacientes com ELT (SLOVITER, 1994). Apesar desta perda neuronial ser identificada em vários subcampos hipocampais (MELLO et al., 1993), em nosso modelo induzido ao $S E$ por Pilocarpina, tal perda celular foi observada na região do hilo. Sabe-se que certas populações neuroniais são mais vulneráveis a intensidade da lesão, portanto, para este desenho experimental, a região do hilo apresentaria células mais suscetíveis e vulneráveis em resposta a Pilocarpina e a intensidade das crises. Como o insulto epileptogênico altera respostas celulares e vias de sinalização (GOTO et al., 2010), é provável que os níveis reduzidos da expressão da Akt total se dêem em resposta à intensidade do 
insulto, mais precisamente à perda neuronial. Durante as crises epilépticas são observadas alterações neuroquímicas como disfunções na atividade da bomba $\mathrm{Na}^{+} / \mathrm{K}^{+}$ATPase associada com hiperexcitabilidade neuronial e o desenvolvimento da epilepsia (CAVALHEIRO et al., 1994; FERNANDES et al., 1996; MCNAMARA, 1994; SCORZA et al., 2009). De acordo com Scorza e colaboradores (2009), a sucessão de eventos celulares decorrentes do processo epileptogênico ativaria canais iônicos e receptores de membrana, resultando em acúmulo de glutamato e elevação dos níveis de cálcio intracelular $\left(\mathrm{Ca}^{++}\right) \cdot \mathrm{O} \mathrm{Ca}^{++}$age como um segundo mensageiro, promovendo a ativação de enzimas presentes no citoplasma, modificando a expressão gênica e a síntese protéica, bem como ativando ou inibindo diversas cascatas de sinalização intracelular dentre elas a Akt (DE OLIVEIRA et al., 2008). Segundo Dong e colaboradores (2007), em um modelo experimental in vitro de C. elegans, o complexo $\mathrm{Ca}^{++}$/ calmodulina poderia ser coimunoprecipitado com Akt através do domínio pleckstrin homology $(\mathrm{PH})$ e esta interação poderia regular a atividade cinásica desta enzima promovendo a sua desativação. Este mecanismo envolvendo o complexo $\mathrm{Ca}^{++} /$calmodulina poderia competir com o fosfatidilinositol 3,4,5-trifosfato pela interação com o domínio $\mathrm{PH}$ da Akt, provavelmente liberando a Akt ativa da membrana plasmática e/ou interferindo na sua ligação com o fosfoinositídeo da membrana celular. Para o nosso estudo, é provável que o mecanismo envolvendo o complexo $\mathrm{Ca}^{++} /$calmodulina também corrobore os baixos níveis de expressão da Akt, quer seja interferindo na sua ligação com os fosfolipídeos da membrana ou desencadeando eventos citoplasmáticos e nucleares. Após um dano tecidual, seria ativada enzimas proteolíticas, endonucleases e lipases promovendo uma morte neuronial local (MITANI et al., 1998) e, como conseqüência, baixos níveis de expressão da Akt.

Em função do seu envolvimento com a transdução de sinal, diferenciação e proliferação celular, as proteínas cinases são importantes alvos terapêuticos. Sabe-se que a maior parte do prognóstico de tumores está associada com a desregulação destas proteínas 
através de mutação gênica que culmina em uma expressão aumentada das mesmas (MOHAMMADI et al., 1997). A ativação de proteínas cinases requer o acoplamento de moléculas ligantes (neurotransmissores, hormônios, fatores de crescimento) a seus respectivos receptores de membrana para que sinais bioquímicos disparem e ativem toda uma cascata de sinalização. Receptores de tirosina cinase formam uma grande família de proteínas de membrana, cujo papel é mediar a comunicação intercelular através do reconhecimento de ligantes extracelulares e traduzir a informação em respostas celulares apropriadas. Estes receptores podem disparar e até mesmo inibir respostas fenotípicas levando à adesão, migração, diferenciação e proliferação, sobrevivência e apoptose da célula (GORDUS et al., 2009). No SNC, a relação entre neurotrofinas e as alterações na plasticidade dos circuitos neuroniais podem ajudar a esclarecer a participação destas moléculas nos mecanismos epileptogênicos. Sabe-se que a atividade biológica das neurotrofinas é mediada por receptores de tropomiosina cinase e o seu papel parece estar ligado à plasticidade sináptica relacionada à epilepsia. Como estas moléculas parecem atuar como fatores promotores de epileptogênese ou como substâncias antiepiléptogênicas endógenas (KANDRATAVICIUS et al., 2010), é possível especular sobre o envolvimento desta cascata molecular com outras vias de sinalização. Receptores de tirosina cinase são importantes para ligação de fatores neurotróficos e críticos para ativação de PI3K, portanto, uma vez modificados, eles podem interferir nos passos da sinalização desta enzima e na cascata de fosforilação da Akt.

Segundo Wang e colaboradores (2001), a fosforilação de resíduos de tirosina em receptores para fatores neurotróficos é fundamental na ativação de uma cascata de eventos que culmina na ativação da Akt. Sabe-se que os níveis de fosforilação de resíduos de tirosina são regulados por atividades enzimáticas opostas que fosforilam (tirosina cinase) e desfosforilam (tirosina fosfatases) esses resíduos; portanto, modificações deste processo poderiam colocar em risco toda uma via de sinalização (HUNTER, 1995). Para o nosso 
estudo, é provável que a desregulação de tais receptores tenha ocorrido em resposta à severidade do insulto, neste caso, impedindo a ligação de fatores neurotróficos e ativação da PI3K; portanto, os baixos níveis da expressão da Akt poderiam ser explicados quer seja pela interrupção do processo ou pela resposta à severidade das crises.

Apesar do nosso modelo experimental evidenciar uma diminuição acentuada nos níveis de expressão da proteína Akt, na região do hilo, este estudo também revelou uma maior expressão da Akt total, no subcampo CA2, para o grupo LY+Pilo em comparação com o grupo Wort+Pilo. De acordo com o estudo de Yano e colaboradores (2001), diferenças regionais para a expressão da Akt seriam demonstradas em modelos de isquemia global, nos quais os graus de dano celular poderiam revelar diferenças regionais na ativação desta proteína. Este grupo investigou que, para o subcampo CA1, a fosfo-Akt seria desfosforilada após o insulto isquêmico e refosforilada acima dos níveis normais após 5 minutos de isquemia global por cerca de 6 horas, sendo constatada uma alteração nos níveis de expressão total para esta proteína. Por outro lado, para o subcampo CA3 e para o GD, nenhuma alteração foi observada quanto ao grau de fosforilação em resposta à indução da isquemia. Segundo Yano e colaboradores (2001), a diferença na severidade isquêmica poderia refletir diferenças nos níveis de fosfo-Akt no subcampo CA1, onde danos letais reduziriam a fosfo-Akt e danos subletais poderiam aumentar a fosfo-Akt num período de 7 dias após a isquemia global. Assim, é possível afirmar que, na isquemia cerebral focal, a fosforilação da Akt é dependente da severidade do estresse, refletindo, assim, níveis de fosfo-Akt em diferentes áreas regionais. Como não foi possível a quantificação dos níveis de fosfo-Akt no nosso estudo, é provável que a maior expressão da proteína total no grupo LY294002 se dê em resposta a uma menor perda celular no subcampo CA2 frente ao insulto epileptogênico. Entretanto, esperar-se-ia valores inalterados da Akt total na presença de LY294002, confirmando o bloqueio de PI3K e a inativação da Akt. Com relação à intensidade do insulto epileptogênico, não é possível 
afirmar que o insulto tenha sido um fator desencadeante para uma maior expressão da Akt, já que nosso modelo experimental não avaliou os níveis de Akt total e fosforilada frente às crises epilépticas. Alguns dados da literatura afirmam que o subcampo CA2 apresenta peculiaridades diferentes de CA1 e CA3, tais como reduzidas conexões intrínsecas e extrínsecas. Existe uma grande quantidade de proteínas ligantes de cálcio e neurotransmissores inibitórios que poderiam explicar a resistência do subcampo CA2 em resposta as crises epilépticas (GLOOR et al., 1997). Neste caso, é possível que a ativação de outros substratos e vias de sinalização tenham contribuído para uma expressão aumentada da Akt, independentemente da inibição de PI3K pelo inibidor farmacológico LY294002.

Em resposta aos níveis da expressão da Akt encontrados nos grupos LY+Pilo, Wort+Pilo e Sal+Pilo, decidimos por analisar a expressão desta proteína somente nos animais induzido ao $S E$ com Pilocarpina em períodos de sobrevida de um ou sete dias. A expressão da Akt para o grupo Sal+Pilo com sobrevida-7 dias revelou níveis maiores da expressão desta proteína, na região do hilo, quando comparado com os animais de sobrevida-1 dia. Este resultado também foi confirmado na camada granular através das médias dos vários níveis de formação hipocampal; entretanto, sem resultados significativos para as regiões posteriores. De certa forma e em proximidade com o tempo de sobrevida dos animais, o estudo de Goto e colaboradores (2010) analisou a via da Akt e da ILK no hipocampo de ratos induzidos ao SE, por meio da injeção intraperitoneal de Pilocarpina e constatou níveis aumentados da Akt fosforilada em animais de sobrevida-5 dias. Neste mesmo período de 5 dias, o estudo de Goto também detectou níveis aumentados da ILK, uma proteína cinase ligada à integrina, cujo papel também estaria relacionado a perda neuronial no hipocampo, processos epileptogênicos e provavelmente mecanismos neuroprotetores (FUERST et al., 2003; MELDRUM et al., 1992; MELLO et al., 1993). Para o nosso estudo, os animais de sobrevida-1 dia pós $S E$ apresentaram uma maior perda neuronial, sugerindo que a expressão da Akt também esteja 
reduzida; para os animais de sobrevida-7 dias esta expressão encontrou-se aumentada. Muito provavelmente, a diferença entre as expressões da Akt citadas foi devido ao tempo sobrevida dos animais, uma vez que, a severidade do insulto pode influenciar na expressão Akt. Sendo assim, a região do hilo, considerada mais suscetível e vulnerável aos danos excitotóxicos da Pilo, apresenta maior dano celular, portanto, levando a menores níveis da expressão da proteína Akt nos animais com sobrevida-1 dia. Para a camada granular, os menores níveis da expressão da Akt podem ser justificados em resposta à severidade das crises que culmina na liberação de aminoácidos excitatórios e que, por sua vez, ativam os canais de cálcio determinando o influxo deste elemento em estruturas celulares que alteram a homeostase intracelular.

De acordo com o estudo de Oliveira e colaboradores (2008), os efeitos do $S E$ induzido por LiCl-Pilocarpina (i.c.v.) no hipocampo de ratos jovens com 15 dias de sobrevida demonstrou uma diminuição da expressão da Akt fosforilada no subcampo CA1 e giro denteado 1,5 hora após a indução do $S E$, enquanto no giro denteado a redução da fosforilação da Akt permaneceu até 24 horas após a indução do insulto. Segundo Oliveira, a diminuição da fosforilação da Akt pode estar relacionada com a intensa morte neuronial observada no período de 24 horas após a administração da Pilocarpina. Deste modo, é provável que os níveis maiores da expressão da Akt em animais com sobrevida-7 dias tenham sido revelados em resposta a uma menor perda celular quando comparados àqueles animais com sobrevida-1 dia. Apesar do tempo de sobrevida de sete dias ser considerado um período curto, tal resultado nos leva a especular sobre o envolvimento da ativação de moléculas endógenas neuroprotetoras e mecanismos de neurogênese envolvidos na Epilepsia. (GOTO et al., 2010; PARENT et al., 1997; SCHLETT, 2006). A expressão aumentada do neuropeptídeo Y no hipocampo de ratos epilépticos tem sido reportada em modelos experimentais de epilepsia incluindo SE, kindling e crises induzidas geneticamente. Na verdade, a alta expressão desta 
molécula consiste de níveis aumentados de RNAm associado ao peptídeo em células granulares, fibras musgosas e interneurônios hílares (VEZZANI e SPERK, 2004; VEZZANI et al., 1999). Sabe-se que a indução das crises altera a expressão do neuropeptídeo Y e modifica o seu receptor sugerindo uma neurotransmissão modificada no tecido epiléptico. De acordo com Goto e colaboradores (2010), em crises não muito longas ou na ausência das crises, este neuropeptídeo Y mRNA é fortemente detectado e pode ser considerado um neuropeptídeo antiepiléptico.

Em cérebros adultos, a neurogênese é modulada por condições fisiológicas e patológicas e que em vários modelos animais a indução de crises através de Pilocarpina e Cainato estimula a neurogênese na zona subgranular do giro denteado. $O$ estudo com imunomarcador de proliferação celular (BrdU) tem revelado que animais tratados com Pilocarpina no período de 7-28 dias revelam uma progressiva dispersão de células marcadas por toda a camada granular quando comparados ao grupo controle. Sendo assim, uma parte das novas células geradas migra para a camada granular e desenvolvem características de células granulares diferenciadas (PARENT et al., 1997). Esse aumento é observado após um certo período de latência, poucos dias após a indução do $S E$, persistindo na primeira semana e retornando a níveis basais na semana seguinte. Estas novas células produzidas diferenciam-se em neurônios migrando para regiões como camada molecular interna, região do hilo e subcampo CA3 (SCHARFMAN et al., 2000). Neste caso, sugere-se que frente ao dano celular induzido pelo $S E$ os animais com sobrevida de sete dias, poderiam, possivelmente, estar ativando mecanismos endógenos para a sobrevivência celular estimulando a neurogênese em resposta a lesão cerebral.

De acordo com estudo de Goto e colaboradores (2010), as vias de sinalização da Akt e da ILK seriam participativas durante todo processo epileptogênico. Na fase crônica do $S E$, tais animais induzidos ao insulto poderiam apresentar níves baixos da proteína ILK e estes níveis 
seriam suficientes para manutenção da Akt em atividade. Aparentemente, esta atividade da Akt seria uma resposta adaptativa frente a um dano celular, na qual a Akt estaria se moldando desde o período da fase aguda, na tentativa de diminuir a extensão da lesão e o número de estruturas cerebrais envolvidas durante o insulto epileptogênico. Portanto, a participação de outras vias que não a Akt em crises epilépticas nos leva a especular sobre uma rede de sinalização neste processo e quais seriam as possíveis respostas em período de fase tardia. Nosso desenho experimental foi elaborado para a avaliação do efeito do $S E$ na ativação da Akt em animais de fase aguda, mas acreditamos que o estudo sobre a expressão da Akt em modelos experimentais de fase crônica poderia elucidar a participação desta via em resposta a crises tardias, permitindo, assim, ter um conhecimento mais amplo desta cascata de sinalização.

A hipótese inicial deste trabalho se deteve em modular a expressão da proteína Akt em resposta ao insulto epileptogênico e analisar os efeitos do bloqueio desta cascata sobre as alterações patológicas no hipocampo. O status epilepticus, a curto prazo, induziu alterações a nível celular e molecular como visto na expressão da proteína Akt, permitindo observar que níveis menores da expressão desta proteína estariam relacionados com maior perda celular, levantando a hipótese de que a severidade do insulto colabore com os menores níveis de expressão da Akt e tais níveis sejam ainda menores naqueles animais induzidos ao $S E$ com sobrevida de um dia.

A excessiva perda celular observada na região do hilo pode estar associada ao sítio de injeção da droga e, por sua vez, à vulnerabilidade celular provocada pelos danos excitotóxicos da Pilo. No entanto, a análise dos efeitos do bloqueio desta cascata com o uso de LY294002 e Wortmanina não revelou alterações patológicas acentuadas quando comparada aos animais tratados somente com Pilocarpina, sugerindo que fatores intrínsecos ligados ao insulto epileptogênico tenham interferido no mecanismos de bloqueio destas drogas e, portanto, nos 
efeitos sobre PI3K e na fosforilação da Akt. Considerando a indução do estado de mal epiléptico pela administração da Pilocarpina e as alterações neuropatológicas e neuroquímicas observadas nos animais, torna-se de grande importância avaliar os efeitos separadamente da Akt total, Akt fosforilada e a relação entre elas, tendo em vista que apenas o estudo para uma delas pode não evidenciar o que está ocorrendo de fato com a regulação desta proteína.

Outro ponto importante é que pode estar existindo a participação de outras moléculas, tais como a ILK, PDK1 e mTOR (BRUNN et al., 1996; GOTO et al., 2010; ORCY et al., 2008), no processo de ativação da Akt e na cascata de sinais extra e intracelulares neuroprotetores. Desta forma, o papel da Akt em relação ao insulto epileptogênico pode ser mais complexo que o originalmente proposto, não cabendo aqui eliminar a hipótese de que outras vias de sinalização assim como, o envolvimento de neuropeptídeos, neurotrofinas, mecanismos excitatórios e neuroquímicos estejam participando ativamente nesta intricada cascata molecular de sobrevivência celular e ativando processos neuroprotetores, até então pouco estudado, durante o status epilepticus. 
7. CONCLUSÃO 


\section{CONCLUSÃO}

Os resultados deste trabalho nos permitem concluir:

1. A utilização de DMSO como veículo para os inibidores de PI3K não produziu toxicidade celular e nem interferências nos níveis de fosforilação da via de sinalização da Akt.

2. A Wortmanina revelou uma ação protetora mais eficiente que LY294002 para a evolução das crises epilépticas.

3. A análise da densidade celular revelou que na região do hilo os grupos tratados com LY294002 e Wortmanina exibiram menor perda neuronial em relação ao grupo Sal+Pilo, sugerindo que os inibidores farmacológicos não inibiram PI3K e não modificaram a via da Akt quando do insulto epileptogênico.

4. É provável que o maior grau de astrogliose, na camada granular, para o grupo LY+Pilo, dê-se em resposta à lesão tecidual associada ao mecanismo de morte celular (apoptose ou necrose) induzido pelo insulto epileptogênico; porém, é questionável se o período de 7 dias é um tempo suficiente para a quantificação da proteína glial, sendo que períodos tardios poderiam favorecer a astrogliose.

5. Níveis menores de expressão da Akt nos grupos LY+Pilo e Wort+Pilo, na região do hilo, podem estar associados à perda neuronial em resposta à intensidade do insulto; por outro lado, o grau de dano celular também pode revelar diferenças regionais para ativação da Akt.

6. Para os animais com sobrevida de um dia pós-SE, a redução na expressão para a proteína Akt pode ser decorrente de maior perda celular em resposta à intensidade do insulto. A expressão maior da Akt para os animais com sobrevida de sete dias permite especularmos sobre uma possível ativação de moléculas endógenas neuroprotetoras e neurogênese durante a Epilepsia. 
7. Objetivando uma melhor compreensão do complexo mecanismo de sobrevivência celular, é necessário uma análise em separado da expressão da Akt total, Akt fosforilada e a relação entre elas, bem como testar a hipótese do envolvimento de outras moléculas e vias de sinalização durante o status epilepticus. 
8. REFERÊNCIAS BIBLIOGRÁFICAS 


\section{REFERÊNCIAS BIBLIOGRÁFICAS}

ABERCROMBIE, M. Estimation of nuclear population from microtome sections. Anatomical Record, v.94, 274-329. 1946.

AJTAI, B.M. ; KALMAN, M. Glial fibrillary acidic protein expression but no glial demarcation follows the lesion in the molecular layer of cerebellum. Brain Res, v.802, 285-288. 1998.

ALESSI, D.R. ; ANDJELKOVIC, M. ; CAUDWELL, B. ; CRON, P. ; MORRICE, N., et al. Mechanism of activation of protein kinase B by insulin and IGF-1. EMBO J, v.15, 6541-6551. 1996.

ARZIMANOGLOU, A. ; HIRSCH, E. ; NEHLIG, A. ; CASTELNAU, P. ; GRESSENS, P. ; PEREIRA DE VASCONCELOS, A. Epilepsy and neuroprotection: an illustrated review. Epileptic Disord, v.4, 173-182. 2002.

BABB, T.L. ; BROWN, W.J. ; PRETORIUS, J. ; DAVENPORT, C. ; LIEB, J.P. ; CRANDALL, P.H. Temporal lobe volumetric cell densities in temporal lobe epilepsy. Epilepsia, v.25, 729-740. 1984a.

BABB, T.L. ; LIEB, J.P. ; BROWN, W.J. ; PRETORIUS, J. ; CRANDALL, P.H. Distribution of pyramidal cell density and hyperexcitability in the epileptic human hippocampal formation. Epilepsia, v.25, 721-728. 1984b.

BALENDRAN, A. ; CASAMAYOR, A. ; DEAK, M. ; PATERSON, A. ; GAFFNEY, P., et al. PDK1 acquires PDK2 activity in the presence of a synthetic peptide derived from the carboxyl terminus of PRK2. Curr Biol, v.9, 393-404. 1999.

BERG, A.T. ; BERKOVIC, S.F. ; BRODIE, M.J. ; BUCHHALTER, J. ; CROSS, J.H., et al. Revised terminology and concepts for organization of seizures and epilepsies: report of the ILAE Commission on Classification and Terminology, 2005-2009. Epilepsia, v.51, 676-685. 2010.

BERTRAM, E. The relevance of kindling for human epilepsy. Epilepsia, v.48 Suppl 2, 65 74. 2007.

BRAYTON, C.F. Dimethyl sulfoxide (DMSO): a review. Cornell Vet, v.76, 61-90. 1986.

BRAZIL, D.P. ; HEMMINGS, B.A. Ten years of protein kinase B signalling: a hard Akt to follow. Trends Biochem Sci, v.26, 657-664. 2001.

BRAZIL, D.P. ; PARK, J. ; HEMMINGS, B.A. PKB binding proteins. Getting in on the Akt. Cell, v.111, 293-303. 2002.

BRUNN, G.J. ; WILLIAMS, J. ; SABERS, C. ; WIEDERRECHT, G. ; LAWRENCE, J.C., JR. ; ABRAHAM, R.T. Direct inhibition of the signaling functions of the mammalian target of rapamycin by the phosphoinositide 3-kinase inhibitors, wortmannin and LY294002. EMBO J, v.15, 5256-5267. 1996.

CARDONE, M.H. ; ROY, N. ; STENNICKE, H.R. ; SALVESEN, G.S. ; FRANKE, T.F., et al. Regulation of cell death protease caspase-9 by phosphorylation. Science, v.282, 1318-1321. 1998.

CARPENTER, C.L. ; DUCKWORTH, B.C. ; AUGER, K.R. ; COHEN, B. ; SCHAFFHAUSEN, B.S. ; CANTLEY, L.C. Purification and characterization of phosphoinositide 3-kinase from rat liver. J Biol Chem, v.265, 19704-19711. 1990.

CAVALHEIRO, E.A. ; LEITE, J.P. ; BORTOLOTTO, Z.A. ; TURSKI, W.A. ; IKONOMIDOU, C. ; TURSKI, L. Long-term effects of pilocarpine in rats: structural damage of the brain triggers kindling and spontaneous recurrent seizures. Epilepsia, v.32, 778-782. 1991. 
CAVALHEIRO, E.A. ; FERNANDES, M.J. ; TURSKI, L. ; NAFFAH-MAZZACORATTI, M.G. Spontaneous recurrent seizures in rats: amino acid and monoamine determination in the hippocampus. Epilepsia, v.35, 1-11. 1994.

CAVALHEIRO, E.A. The pilocarpine model of epilepsy. Ital J Neurol Sci, v.16, 33-37. 1995.

CERESER, K.M. ; FREY, B.N. ; BERNARDES, F.B. ; COSTA, S.C. ; ANDREAZZA, A.C., et al. Glial fibrillary acidic protein expression after electroconvulsive shocks in rat brain. Prog Neuropsychopharmacol Biol Psychiatry, v.30, 663-667. 2006.

CHASSEROT-GOLAZ, S. ; HUBERT, P. ; THIERSE, D. ; DIRRIG, S. ; VLAHOS, C.J., et al. Possible involvement of phosphatidylinositol 3-kinase in regulated exocytosis: studies in chromaffin cells with inhibitor LY294002. J Neurochem, v.70, 2347-2356. 1998.

CHONG, Z.Z. ; LIN, S.H. ; KANG, J.Q. ; MAIESE, K. The tyrosine phosphatase SHP2 modulates MAP kinase p38 and caspase 1 and 3 to foster neuronal survival. Cell Mol Neurobiol, v.23, 561-578. 2003.

CLIFFORD, D.B. ; OLNEY, J.W. ; MANIOTIS, A. ; COLLINS, R.C. ; ZORUMSKI, C.F. The functional anatomy and pathology of lithium-pilocarpine and high-dose pilocarpine seizures. Neuroscience, v.23, 953-968. 1987.

COFFER, P.J. ; JIN, J. ; WOODGETT, J.R. Protein kinase B (c-Akt): a multifunctional mediator of phosphatidylinositol 3-kinase activation. Biochem J, v.335 ( Pt 1), 1-13. 1998.

CROWDER, R.J. ; FREEMAN, R.S. Phosphatidylinositol 3-kinase and Akt protein kinase are necessary and sufficient for the survival of nerve growth factor-dependent sympathetic neurons. J Neurosci, v.18, 2933-2943. 1998.

DASH, P.K. ; MACH, S.A. ; BLUM, S. ; MOORE, A.N. Intrahippocampal wortmannin infusion enhances long-term spatial and contextual memories. Learn Mem, v.9, 167177. 2002.

DATTA, B. ; DATTA, R. Induction of apoptosis due to lowering the level of eukaryotic initiation factor 2-associated protein, p67, from mammalian cells by antisense approach. Exp Cell Res, v.246, 376-383. 1999.

DAVENPORT, C.J. ; BROWN, W.J. ; BABB, T.L. Sprouting of GABAergic and mossy fiber axons in dentate gyrus following intrahippocampal kainate in the rat. Exp Neurol, v.109, 180-190. 1990.

DE OLIVEIRA, D.L. ; FISCHER, A. ; JORGE, R.S. ; DA SILVA, M.C. ; LEITE, M., et al. Effects of early-life LiCl-pilocarpine-induced status epilepticus on memory and anxiety in adult rats are associated with mossy fiber sprouting and elevated CSF S100B protein. Epilepsia, v.49, 842-852. 2008.

DIMMELER, S. ; ZEIHER, A.M. Akt takes center stage in angiogenesis signaling. Circ Res, v.86, 4-5. 2000.

DONG, B. ; VALENCIA, C.A. ; LIU, R. Ca(2+)/calmodulin directly interacts with the pleckstrin homology domain of AKT1. J Biol Chem, v.282, 25131-25140. 2007.

DOWNWARD, J. Mechanisms and consequences of activation of protein kinase B/Akt. Curr Opin Cell Biol, v.10, 262-267. 1998.

EL BAHH, B. ; AUVERGNE, R. ; LERE, C. ; BRANA, C. ; LE GAL LA SALlE, G. ; ROUGIER, A. Decreased epileptic susceptibility correlates with neuropeptide Y overexpression in a model of tolerance to excitotoxicity. Brain Res, v.894, 209-217. 2001.

ENG, L.F. ; GHIRNIKAR, R.S. GFAP and astrogliosis. Brain Pathol, v.4, 229-237. 1994. 
ENGEL, J., JR. ; BABB, T.L. ; CRANDALL, P.H. Surgical treatment of epilepsy: opportunities for research into basic mechanisms of human brain function. Acta Neurochir Suppl (Wien), v.46, 3-8. 1989.

ENGEL, J., JR. Introduction to temporal lobe epilepsy. Epilepsy research, v.26, 141-150. 1996.

ENGELMAN, J.A. ; LUO, J. ; CANTLEY, L.C. The evolution of phosphatidylinositol 3kinases as regulators of growth and metabolism. Nat Rev Genet, v.7, 606-619. 2006.

FAYARD, B. ; LOEFFLER, S. ; WEIS, J. ; VOGELIN, E. ; KRUTTGEN, A. The secreted brain-derived neurotrophic factor precursor pro-BDNF binds to TrkB and p75NTR but not to TrkA or TrkC. J Neurosci Res, v.80, 18-28. 2005a.

FAYARD, E. ; TINTIGNAC, L.A. ; BAUDRY, A. ; HEMMINGS, B.A. Protein kinase B/Akt at a glance. J Cell Sci, v.118, 5675-5678. 2005b.

FENG, J. ; PARK, J. ; CRON, P. ; HESS, D. ; HEMMINGS, B.A. Identification of a PKB/Akt hydrophobic motif Ser-473 kinase as DNA-dependent protein kinase. J Biol Chem, v.279, 41189-41196. 2004.

FERNANDES, M.J. ; NAFFAH-MAZZACORATTI, M.G. ; CAVALHEIRO, E.A. Na+K+ ATPase activity in the rat hippocampus: a study in the pilocarpine model of epilepsy. Neurochem Int, v.28, 497-500. 1996.

FERRANDI, C. ; ARDISSONE, V. ; FERRO, P. ; RUCKLE, T. ; ZARATIN, P., et al. Phosphoinositide 3-kinase gamma inhibition plays a crucial role in early steps of inflammation by blocking neutrophil recruitment. J Pharmacol Exp Ther, v.322, 923-930. 2007.

FUERST, D. ; SHAH, J. ; SHAH, A. ; WATSON, C. Hippocampal sclerosis is a progressive disorder: a longitudinal volumetric MRI study. Ann Neurol, v.53, 413-416. 2003.

FURTADO, M.A. ; BRAGA, G.K. ; OLIVEIRA, J.A. ; DEL VECCHIO, F. ; GARCIACAIRASCO, N. Behavioral, morphologic, and electroencephalographic evaluation of seizures induced by intrahippocampal microinjection of pilocarpine. Epilepsia, v.43 Suppl 5, 37-39. 2002.

GARZILLO, C.L. ; MELLO, L.E. Characterization of reactive astrocytes in the chronic phase of the pilocarpine model of epilepsy. Epilepsia, v.43 Suppl 5, 107-109. 2002.

GITAI, D.L. ; ROMCY-PEREIRA, R.N. ; GITAI, L.L. ; LEITE, J.P. ; GARCIACAIRASCO, N. ; PACO-LARSON, M.L. [Genes and epilepsy I: epilepsy and genetic alterations]. Rev Assoc Med Bras, v.54, 272-278. 2008.

GLOOR, S.M. ; WEBER, A. ; ADACHI, N. ; FREI, K. Interleukin-1 modulates protein tyrosine phosphatase activity and permeability of brain endothelial cells. Biochem Biophys Res Commun, v.239, 804-809. 1997.

GOLDRING, S. ; EDWARDS, I. ; HARDING, G.W. ; BERNARDO, K.L. Results of anterior temporal lobectomy that spares the amygdala in patients with complex partial seizures. J Neurosurg, v.77, 185-193. 1992.

GORDUS, A. ; KRALL, J.A. ; BEYER, E.M. ; KAUSHANSKY, A. ; WOLF-YADLIN, A., et al. Linear combinations of docking affinities explain quantitative differences in RTK signaling. Mol Syst Biol, v.5, 235. 2009.

GOTO, E.M. ; SILVA MDE, P. ; PEROSA, S.R. ; ARGANARAZ, G.A. ; PESQUERO, J.B., et al. Akt pathway activation and increased neuropeptide $Y$ mRNA expression in the rat hippocampus: implications for seizure blockade. Neuropeptides, v.44, 169-176. 2010.

GOTTLIEB, T.M. ; LEAL, J.F. ; SEGER, R. ; TAYA, Y. ; OREN, M. Cross-talk between Akt, p53 and Mdm2: possible implications for the regulation of apoptosis. Oncogene, v.21, 1299-1303. 2002. 
HANSEN, A. ; JORGENSEN, O.S. ; BOLWIG, T.G. ; BARRY, D.I. Hippocampal kindling alters the concentration of glial fibrillary acidic protein and other marker proteins in rat brain. Brain Res, v.531, 307-311. 1990.

HAUSMANN, R. ; RIESS, R. ; FIEGUTH, A. ; BETZ, P. Immunohistochemical investigations on the course of astroglial GFAP expression following human brain injury. Int J Legal Med, v.113, 70-75. 2000.

HENRY, M.K. ; LYNCH, J.T. ; EAPEN, A.K. ; QUELLE, F.W. DNA damage-induced cellcycle arrest of hematopoietic cells is overridden by activation of the PI-3 kinase/Akt signaling pathway. Blood, v.98, 834-841. 2001.

HENSHALL, D.C. ; BONISLAWSKI, D.P. ; SKRADSKI, S.L. ; LAN, J.Q. ; MELLER, R. ; SIMON, R.P. Cleavage of bid may amplify caspase-8-induced neuronal death following focally evoked limbic seizures. Neurobiol Dis, v.8, 568-580. 2001.

HENSHALL, D.C. ; ARAKI, T. ; SCHINDLER, C.K. ; LAN, J.Q. ; TIEKOTER, K.L., et al. Activation of Bcl-2-associated death protein and counter-response of Akt within cell populations during seizure-induced neuronal death. J Neurosci, v.22, 8458-8465. 2002.

HENSHALL, D.C. ; SIMON, R.P. Epilepsy and apoptosis pathways. J Cereb Blood Flow Metab, v.25, 1557-1572. 2005.

HORN, A.P. ; GERHARDT, D. ; GEYER, A.B. ; VALENTIM, L. ; CIMAROSTI, H., et al. Cellular death in hippocampus in response to PI3K pathway inhibition and oxygen and glucose deprivation. Neurochem Res, v.30, 355-361. 2005.

HOUSER, C.R. Granule cell dispersion in the dentate gyrus of humans with temporal lobe epilepsy. Brain Res, v.535, 195-204. 1990.

HUNTER, T. When is a lipid kinase not a lipid kinase? When it is a protein kinase. Cell, v.83, 1-4. 1995.

JANELIDZE, S. ; HU, B.R. ; SIESJO, P. ; SIESJO, B.K. Alterations of Akt1 (PKBalpha) and p70(S6K) in transient focal ischemia. Neurobiol Dis, v.8, 147-154. 2001.

JIANG, K. ; ZHONG, B. ; RITCHEY, C. ; GILVARY, D.L. ; HONG-GELLER, E., et al. Regulation of Akt-dependent cell survival by Syk and Rac. Blood, v.101, 236-244. 2003a.

JIANG, Z. ; ZHANG, Y. ; CHEN, X.Q. ; LAM, P.Y. ; YANG, H., et al. Apoptosis and activation of Erkl/2 and Akt in astrocytes postischemia. Neurochem Res, v.28, 831837. 2003b.

KANDEL, E.S. ; HAY, N. The regulation and activities of the multifunctional serine/threonine kinase Akt/PKB. Exp Cell Res, v.253, 210-229. 1999.

KANDRATAVICIUS, L. ; MONTEIRO, M.R. ; DO VAL, R.A.S. ; LEITE, J.P. Neurotrophins in temporal lobe epilepsy. Epilepsy clin neurophisiology, v.16, 16762649. 2010.

KANG, Y.M. ; HENSLE, T.W. Improved survival in relapsed Wilms' tumor in the modern era. Curr Urol Rep, v.4, 141. 2003.

KIM, A.H. ; KHURSIGARA, G. ; SUN, X. ; FRANKE, T.F. ; CHAO, M.V. Akt phosphorylates and negatively regulates apoptosis signal-regulating kinase 1. Mol Cell Biol, v.21, 893-901. 2001.

KOHN, A.D. ; TAKEUCHI, F. ; ROTH, R.A. Akt, a pleckstrin homology domain containing kinase, is activated primarily by phosphorylation. J Biol Chem, v.271, 21920-21926. 1996.

KRALIC, J.E. ; LEDERGERBER, D.A. ; FRITSCHY, J.M. Disruption of the neurogenic potential of the dentate gyrus in a mouse model of temporal lobe epilepsy with focal seizures. Eur J Neurosci, v.22, 1916-1927. 2005. 
KUBOVA, H. ; DRUGA, R. ; LUKASIUK, K. ; SUCHOMELOVA, L. ; HAUGVICOVA, R., et al. Status epilepticus causes necrotic damage in the mediodorsal nucleus of the thalamus in immature rats. J Neurosci, v.21, 3593-3599. 2001.

LAWLOR, M.A. ; ALESSI, D.R. PKB/Akt: a key mediator of cell proliferation, survival and insulin responses? J Cell Sci, v.114, 2903-2910. 2001.

LEE, S.H. ; CHUN, W. ; KONG, P.J. ; HAN, J.A. ; CHO, B.P., et al. Sustained activation of Akt by melatonin contributes to the protection against kainic acid-induced neuronal death in hippocampus. J Pineal Res, v.40, 79-85. 2006.

LEITE, J.P. ; BORTOLOTTO, Z.A. ; CAVALHEIRO, E.A. Spontaneous recurrent seizures in rats: an experimental model of partial epilepsy. Neurosci Biobehav Rev, v.14, 511 517. 1990.

LEITE, J.P. ; CAVALHEIRO, E.A. Effects of conventional antiepileptic drugs in a model of spontaneous recurrent seizures in rats. Epilepsy Res, v.20, 93-104. 1995.

LEMAIRE, V. ; KOEHL, M. ; LE MOAL, M. ; ABROUS, D.N. Prenatal stress produces learning deficits associated with an inhibition of neurogenesis in the hippocampus. Proc Natl Acad Sci U S A, v.97, 11032-11037. 2000.

LI, L. ; WU, W. ; LIN, L.F. ; LEI, M. ; OPPENHEIM, R.W. ; HOUENOU, L.J. Rescue of adult mouse motoneurons from injury-induced cell death by glial cell line-derived neurotrophic factor. Proc Natl Acad Sci U S A, v.92, 9771-9775. 1995.

LUO, H.R. ; HATTORI, H. ; HOSSAIN, M.A. ; HESTER, L. ; HUANG, Y., et al. Akt as a mediator of cell death. Proc Natl Acad Sci U S A, v.100, 11712-11717. 2003.

MANNING, B.D. ; CANTLEY, L.C. AKT/PKB signaling: navigating downstream. Cell, V.129, 1261-1274. 2007.

MATSUZAKI, H. ; TAMATANI, M. ; MITSUDA, N. ; NAMIKAWA, K. ; KIYAMA, H., et al. Activation of Akt kinase inhibits apoptosis and changes in Bcl-2 and Bax expression induced by nitric oxide in primary hippocampal neurons. J Neurochem, v.73, 2037-2046. 1999.

MAYO, L.D. ; DONNER, D.B. A phosphatidylinositol 3-kinase/Akt pathway promotes translocation of Mdm2 from the cytoplasm to the nucleus. Proc Natl Acad Sci U S A, v.98, 11598-11603. 2001.

MCNAMARA, J.O. Cellular and molecular basis of epilepsy. J Neurosci, v.14, 3413-3425. 1994.

MELDRUM, B.S. ; VIGOUROUX, R.A. ; BRIERLEY, J.B. Systemic factors and epileptic brain damage. Prolonged seizures in paralyzed, artificially ventilated baboons. Arch Neurol, v.29, 82-87. 1973.

MELDRUM, B.S. ; CRAGGS, M.D. ; DURMULLER, N. ; SMITH, S.E. ; CHAPMAN, A.G. The effects of AMPA receptor antagonists on kindled seizures and on reflex epilepsy in rodents and primates. Epilepsy Res Suppl, v.9, 307-311. 1992.

MELlO, L.E. ; CAVAlHEIRO, E.A. ; TAN, A.M. ; PRETORIUS, J.K. ; BABB, T.L. ; FINCH, D.M. Granule cell dispersion in relation to mossy fiber sprouting, hippocampal cell loss, silent period and seizure frequency in the pilocarpine model of epilepsy. Epilepsy Res Suppl, v.9, 51-59; discussion 59-60. 1992.

MELLO, L.E. ; CAVALHEIRO, E.A. ; TAN, A.M. ; KUPFER, W.R. ; PRETORIUS, J.K., et al. Circuit mechanisms of seizures in the pilocarpine model of chronic epilepsy: cell loss and mossy fiber sprouting. Epilepsia, v.34, 985-995. 1993.

MELLO, L.E. ; COVOLAN, L. Spontaneous seizures preferentially injure interneurons in the pilocarpine model of chronic spontaneous seizures. Epilepsy Res, v.26, 123-129. 1996.

MITANI, A. ; NAMBA, S. ; IKEMUNE, K. ; YANASE, H. ; ARAI, T. ; KATAOKA, K. Postischemic enhancements of N-methyl-D-aspartic acid (NMDA) and non-NMDA 
receptor-mediated responses in hippocampal CA1 pyramidal neurons. J Cereb Blood Flow Metab, v.18, 1088-1098. 1998.

MOHAMMADI, M. ; MCMAHON, G. ; SUN, L. ; TANG, C. ; HIRTH, P., et al. Structures of the tyrosine kinase domain of fibroblast growth factor receptor in complex with inhibitors. Science, v.276, 955-960. 1997.

NAJM, I.M. ; HADAM, J. ; CKAKRAVERTY, D. ; MIKUNI, N. ; PENROD, C., et al. A short episode of seizure activity protects from status epilepticus-induced neuronal damage in rat brain. Brain Res, v.810, 72-75. 1998.

NAMURA, S. ; NAGATA, I. ; KIKUCHI, H. ; ANDREUCCI, M. ; ALESSANDRINI, A. Serine-threonine protein kinase Akt does not mediate ischemic tolerance after global ischemia in the gerbil. J Cereb Blood Flow Metab, v.20, 1301-1305. 2000.

NISHIO, S. ; MORIOKA, T. ; HISADA, K. ; FUKUI, M. Temporal lobe epilepsy: a clinicopathological study with special reference to temporal neocortical changes. Neurosurg Rev, v.23, 84-89. 2000.

NOSHITA, N. ; LEWEN, A. ; SUGAWARA, T. ; CHAN, P.H. Evidence of phosphorylation of Akt and neuronal survival after transient focal cerebral ischemia in mice. J Cereb Blood Flow Metab, v.21, 1442-1450. 2001.

OLNEY, J.W. ; RHEE, V. ; HO, O.L. Kainic acid: a powerful neurotoxic analogue of glutamate. Brain Res, v.77, 507-512. 1974.

OLNEY, J.W. Excitatory transmitter neurotoxicity. Neurobiol Aging, v.15, 259-260. 1994.

ORCY, R.B. ; SCHROEDER, S. ; MARTINS-COSTA, S.H. ; RAMOS, J.G. ; SCHECHINGER, W., et al. Signalization of Akt/PKB in the placenta, skeletal muscle and adipose tissue of preeclampsia patients. Gynecol Obstet Invest, v.66, 231-236. 2008.

OUYANG, Y.B. ; TAN, Y. ; COMB, M. ; LIU, C.L. ; MARTONE, M.E., et al. Survival- and death-promoting events after transient cerebral ischemia: phosphorylation of Akt, release of cytochrome $\mathrm{C}$ and Activation of caspase-like proteases. J Cereb Blood Flow Metab, v.19, 1126-1135. 1999.

OWADA, Y. ; UTSUNOMIYA, A. ; YOSHIMOTO, T. ; KONDO, H. Expression of mRNA for Akt, serine-threonine protein kinase, in the brain during development and its transient enhancement following axotomy of hypoglossal nerve. J Mol Neurosci, v.9, 27-33. 1997.

OZAITA, A. ; PUIGHERMANAL, E. ; MALDONADO, R. Regulation of PI3K/Akt/GSK-3 pathway by cannabinoids in the brain. J Neurochem, v.102, 1105-1114. 2007.

PARENT, J.M. ; YU, T.W. ; LEIBOWITZ, R.T. ; GESCHWIND, D.H. ; SLOVITER, R.S. ; LOWENSTEIN, D.H. Dentate granule cell neurogenesis is increased by seizures and contributes to aberrant network reorganization in the adult rat hippocampus. $\mathbf{J}$ Neurosci, v.17, 3727-3738. 1997.

PAXINOS, G. ; WATSON, C. The rat brain in stereotaxic coordinates.

California- United States, 1986.

PERSAD, S. ; ATTWELL, S. ; GRAY, V. ; MAWJI, N. ; DENG, J.T., et al. Regulation of protein kinase B/Akt-serine 473 phosphorylation by integrin-linked kinase: critical roles for kinase activity and amino acids arginine 211 and serine 343. J Biol Chem, v.276, 27462-27469. 2001.

PORTERA-CAILlIAU, C. ; SUNG, C.H. ; NATHANS, J. ; ADLER, R. Apoptotic photoreceptor cell death in mouse models of retinitis pigmentosa. Proc Natl Acad Sci U S A, v.91, 974-978. 1994.

POWIS, G. ; BONJOUKLIAN, R. ; BERGGREN, M.M. ; GALLEGOS, A. ; ABRAHAM, R., et al. Wortmannin, a potent and selective inhibitor of phosphatidylinositol-3kinase. Cancer Res, v.54, 2419-2423. 1994. 
RACINE, R.J. Modification of seizure activity by electrical stimulation. II. Motor seizure. Electroencephalogr Clin Neurophysiol, v.32, 281-294. 1972.

SACONATO, H. ; PRADO, G.F. ; PUGA, M.E. ; ATALLAH, A.N. Oxcarbazepine for refractory epilepsy: systematic review of the literature. Sao Paulo Med J, v.127, 150159. 2009.

SANDER, J.W. The epidemiology of epilepsy revisited. Curr Opin Neurol, v.16, 165-170. 2003.

SANKAR, R. ; SHIN, D.H. ; WASTERLAIN, C.G. Serum neuron-specific enolase is a marker for neuronal damage following status epilepticus in the rat. Epilepsy Res, v.28, 129-136. 1997.

SARBASSOV, D.D. ; GUERTIN, D.A. ; ALI, S.M. ; SABATINI, D.M. Phosphorylation and regulation of Akt/PKB by the rictor-mTOR complex. Science, v.307, 1098-1101. 2005.

SCHARFMAN, H.E. ; GOODMAN, J.H. ; SOLLAS, A.L. Granule-like neurons at the hilar/CA3 border after status epilepticus and their synchrony with area CA3 pyramidal cells: functional implications of seizure-induced neurogenesis. J Neurosci, v.20, 6144-6158. 2000.

SCHLETT, K. Glutamate as a modulator of embryonic and adult neurogenesis. Curr Top Med Chem, v.6, 949-960. 2006.

SCORZA, F.A. ; ARIDA, R.M. ; NAFFAH-MAZZACORATTI MDA, G. ; SCERNI, D.A. ; CALDERAZZO, L. ; CAVALHEIRO, E.A. The pilocarpine model of epilepsy: what have we learned? An Acad Bras Cienc, v.81, 345-365. 2009.

SLOVITER, R.S. Decreased hippocampal inhibition and a selective loss of interneurons in experimental epilepsy. Science, v.235, 73-76. 1987.

---. On the relationship between neuropathology and pathophysiology in the epileptic hippocampus of humans and experimental animals. Hippocampus, v.4, 250-253. 1994.

SOFRONIEW, M.V. Molecular dissection of reactive astrogliosis and glial scar formation. Trends Neurosci, v.32, 638-647. 2009.

SONG, G. ; OUYANG, G. ; BAO, S. The activation of Akt/PKB signaling pathway and cell survival. J Cell Mol Med, v.9, 59-71. 2005.

SORENSEN, A.T. ; NIKITIDOU, L. ; LEDRI, M. ; LIN, E.J. ; DURING, M.J., et al. Hippocampal NPY gene transfer attenuates seizures without affecting epilepsyinduced impairment of LTP. Exp Neurol, v.215, 328-333. 2009.

STAAL, S.P. ; HARTLEY, J.W. ; ROWE, W.P. Isolation of transforming murine leukemia viruses from mice with a high incidence of spontaneous lymphoma. Proc Natl Acad Sci U S A, v.74, 3065-3067. 1977.

TAKANO, T. ; NAKATA, K. ; KAWAKAMI, T. ; MIYAZAKI, Y. ; MURAKAMI, M., et al. Validation of a toxicity testing model by evaluating oxygen supply and energy state in the isolated perfused rat kidney. Single-pass preparation without albumin. J Pharmacol Methods, v.25, 195-204. 1991.

THIMMAIAH, K.N. ; EASTON, J.B. ; GERMAIN, G.S. ; MORTON, C.L. ; KAMATH, S., et al. Identification of N10-substituted phenoxazines as potent and specific inhibitors of Akt signaling. J Biol Chem, v.280, 31924-31935. 2005.

TOKER, A. ; NEWTON, A.C. Akt/protein kinase B is regulated by autophosphorylation at the hypothetical PDK-2 site. J Biol Chem, v.275, 8271-8274. 2000.

TSANKOVA, N.M. ; KUMAR, A. ; NESTLER, E.J. Histone modifications at gene promoter regions in rat hippocampus after acute and chronic electroconvulsive seizures. $\mathbf{J}$ Neurosci, v.24, 5603-5610. 2004. 
TURSKI, L. ; IKONOMIDOU, C. ; TURSKI, W.A. ; BORTOLOTTO, Z.A. ; CAVALHEIRO, E.A. Review: cholinergic mechanisms and epileptogenesis. The seizures induced by pilocarpine: a novel experimental model of intractable epilepsy. Synapse, v.3, 154-171. 1989.

TURSKI, W.A. ; CAVALHEIRO, E.A. ; BORTOLOTTO, Z.A. ; MELLO, L.M. ; SCHWARZ, M. ; TURSKI, L. Seizures produced by pilocarpine in mice: a behavioral, electroencephalographic and morphological analysis. Brain Res, v.321, 237-253. 1984.

UI, M. ; OKADA, T. ; HAZEKI, K. ; HAZEKI, O. Wortmannin as a unique probe for an intracellular signalling protein, phosphoinositide 3-kinase. Trends Biochem Sci, v.20, 303-307. 1995.

VEZZANI, A. ; SPERK, G. ; COLMERS, W.F. Neuropeptide Y: emerging evidence for a functional role in seizure modulation. Trends Neurosci, v.22, 25-30. 1999.

VEZZANI, A. ; SPERK, G. Overexpression of NPY and Y2 receptors in epileptic brain tissue: an endogenous neuroprotective mechanism in temporal lobe epilepsy? Neuropeptides, v.38, 245-252. 2004.

VEZZANI, A. ; GRANATA, T. Brain inflammation in epilepsy: experimental and clinical evidence. Epilepsia, v.46, 1724-1743. 2005.

VINIEGRA, J.G. ; MARTINEZ, N. ; MODIRASSARI, P. ; LOSA, J.H. ; PARADA COBO, $\mathrm{C}$, , et al. Full activation of $\mathrm{PKB} / \mathrm{Akt}$ in response to insulin or ionizing radiation is mediated through ATM. J Biol Chem, v.280, 4029-4036. 2005.

VLAHOS, C.J. ; MATTER, W.F. ; HUI, K.Y. ; BROWN, R.F. A specific inhibitor of phosphatidylinositol 3-kinase, 2-(4-morpholinyl)-8-phenyl-4H-1-benzopyran-4-one (LY294002). J Biol Chem, v.269, 5241-5248. 1994.

WANG, X.Q. ; SUN, P. ; PALLER, A.S. Inhibition of integrin-linked kinase/protein kinase B/Akt signaling: mechanism for ganglioside-induced apoptosis. J Biol Chem, v.276, 44504-44511. 2001.

WASTERLAIN, C.G. ; FUJIKAWA, D.G. ; PENIX, L. ; SANKAR, R. Pathophysiological mechanisms of brain damage from status epilepticus. Epilepsia, v.34 Suppl 1, S37-53. 1993.

WICK, A. ; WICK, W. ; WALTENBERGER, J. ; WELLER, M. ; DICHGANS, J. ; SCHULZ, J.B. Neuroprotection by hypoxic preconditioning requires sequential activation of vascular endothelial growth factor receptor and Akt. J Neurosci, v.22, 6401-6407. 2002.

WYLLIE, A.H. ; KERR, J.F. ; CURRIE, A.R. Cell death: the significance of apoptosis. Int Rev Cytol, v.68, 251-306. 1980.

WYMANN, M.P. ; BULGARELli-LEVA, G. ; ZVELEBIL, M.J. ; PIROLA, L. ; VANHAESEBROECK, B., et al. Wortmannin inactivates phosphoinositide 3-kinase by covalent modification of Lys-802, a residue involved in the phosphate transfer reaction. Mol Cell Biol, v.16, 1722-1733. 1996.

YANG, L. ; LEE, O. ; CHEN, J. ; CHANG, C.C. ; ZHOU, P., et al. Human acyl-coenzyme A:cholesterol acyltransferase 1 (acat1) sequences located in two different chromosomes (7 and 1) are required to produce a novel ACAT1 isoenzyme with additional sequence at the $\mathrm{N}$ terminus. J Biol Chem, v.279, 46253-46262. 2004.

YANO, S. ; MORIOKA, M. ; FUKUNAGA, K. ; KAWANO, T. ; HARA, T., et al. Activation of Akt/protein kinase B contributes to induction of ischemic tolerance in the CA1 subfield of gerbil hippocampus. J Cereb Blood Flow Metab, v.21, 351-360. 2001. 
YOSHIMOTO, T. ; UCHINO, H. ; HE, Q.P. ; LI, P.A. ; SIESJO, B.K. Cyclosporin A, but not FK506, prevents the downregulation of phosphorylated Akt after transient focal ischemia in the rat. Brain Res, v.899, 148-158. 2001.

YUAN, J. ; YANKNER, B.A. Apoptosis in the nervous system. Nature, v.407, 802-809. 2000. 